Portland State University

PDXScholar

Summer 1-1-2012

\title{
Anna of Denmark: Expressions of Autonomy and Agency as a Royal Wife and Mother
}

Anastasia Christine Baker

Portland State University

Follow this and additional works at: https://pdxscholar.library.pdx.edu/open_access_etds

Part of the European History Commons, European Languages and Societies Commons, and the Medieval History Commons

Let us know how access to this document benefits you.

\section{Recommended Citation}

Baker, Anastasia Christine, "Anna of Denmark: Expressions of Autonomy and Agency as a Royal Wife and Mother" (2012). Dissertations and Theses. Paper 713.

https://doi.org/10.15760/etd.713

This Thesis is brought to you for free and open access. It has been accepted for inclusion in Dissertations and Theses by an authorized administrator of PDXScholar. Please contact us if we can make this document more accessible: pdxscholar@pdx.edu. 
Anna of Denmark: Expressions of Autonomy and Agency as a

Royal Wife and Mother

by

Anastasia Christine Baker

A thesis submitted in partial fulfillment of the

requirements for the degree of

\author{
Master of Arts \\ in \\ History
}

Thesis Committee:

Caroline Litzenberger, Chair

John Ott

David Johnson

Amy Greenstadt

Portland State University

(C)2012 
$\underline{\text { Abstract }}$

Anna of Denmark (12 December 1574 - 2 March 1619), the wife of King James VI/I of Scotland, England, and Ireland, was an intelligent and interesting woman who has, up until recently, been largely ignored by history. It has only been within the past two decades that any in-depth analysis of Anna has been done, and most of that analysis has focused on Anna's work with the Stuart court masque. The intent of this thesis has been to expand upon current scholarship regarding Anna, as well as to synthesize the various facets of Anna's life in order to put together a more comprehensive understanding of who Anna was and the various ways in which she expressed personal agency and autonomy as a queen consort as opposed to a queen regnant, and how she used the roles of royal wife and mother to further her own goals and interests.

The work is divided into an introduction, three chapters, and a conclusion. The introduction offers a brief analysis of the primary and secondary sources, and details how these sources were used within the broader scope of the paper. This introductory section also examines Anna's early life in Denmark, her wedding, and her initial journey to Scotland. The second chapter focuses on Anna's relationships with her husband and children, and particularly how Anna established a niche for herself within first the Scottish, and later the English courts. By studying these relationships it is possible to study the ways in which Anna, as a queen consort, was able to create a court presence for herself. Chapter three analyzes Anna's relationships with other courtiers and, more specifically, what these relationships tell modern scholars about how Anna was able to exercise political influence and power both directly and indirectly. Anna's interactions with her courtiers illustrate how well she understood not only human nature, but the 
nature of court culture and politics. The fourth chapter presents an in-depth study of Anna's masquing career, and looks at how Anna used the court masque to not only establish a female presence on the stage, but also to fashion a public image for herself. Anna used the Stuart court masque in a way that no one had previously: she used it to express her social and political opinions, and through the court masque Anna was able to portray both who she was and how she wanted to be perceived. The final chapter covers Anna's final days and her lasting impact on English history.

Anna of Denmark deserves to be brought out of the shadows of history, and this thesis has attempted to do just that. She was a bright, engaging young woman who, unfortunately, has largely been overshadowed by her husband and children. By studying Anna's various roles as wife, mother, friend, benefactor, and patron, it has been possible to bring forth a much more complete understanding of who this queen consort was and why she is important to a broader understanding of early modern English history. 
$\underline{\text { Dedication }}$

To Dallin, Alice, and Hellen. Thanks for everything. 


\section{$\underline{\text { Acknowledgments }}$}

iv

This thesis would not have been possible without the support of many people. The author wishes to express her gratitude to her advisor, Dr. Caroline Litzenberger, who was very helpful and offered assistance, support and guidance. Deepest gratitude is also due to the members of her thesis committee, Dr. David Johnson, Dr. John Ott, and Dr. Amy Greenstadt, without whose knowledge and assistance this thesis would not have been successful.

Special thanks are also due to the author's friends in the Portland State University history department, especially Anna Wilson, William Thompson, James Louderman, Daniel Pearson, Meghan Connolly, and Joshua Bryan. Without their support, guidance, humor, and friendship this thesis would not have been possible. Also, the author wishes to thank Dr. Dustin Walcher of Southern Oregon University, whose advice and encouragement was invaluable during the graduate school process.

The author wishes to express her love and gratitude to her family, especially Dallin Baker, Sandi and Allen Hart, Claire Glasgow, Michelle Bailey Baker, Vicki Osaki, and Linda Williams, for their understanding, patience, and love through the duration of her studies. 


\section{$\underline{\text { Table of Contents }}$}

Abstract

Chapter One

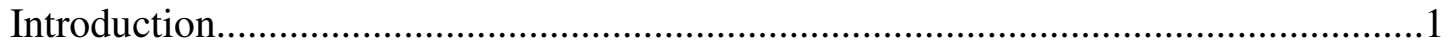

Chapter Two

Anna as a Royal Wife and Mother.......................................................................28

Chapter Three

Anna as an Independent Political Entity.........................................................67

Chapter Four

Anna's Masquing Career and the Development of a Female Identity

on the Court Stage.

Chapter Five

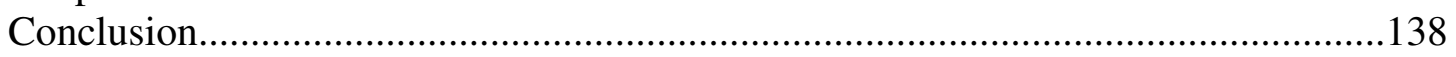

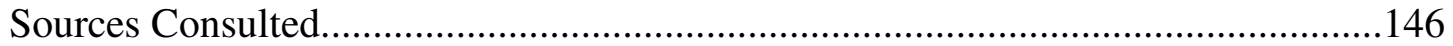


Chapter One: Introduction

In the scope of Early Modern English history, the reign of King James VI/I of Scotland and England has often been eclipsed by the splendor of his relative and predecessor, Queen Elizabeth I, and by the negative legacy of his son and successor, the ill-fated Charles I. James himself is remembered as a king who was an intellectual man whose great ambition was to unify the great Christian kingdoms of Europe. His wife, Anna of Denmark, has received considerably less attention. Anna was, however, a bright and engaging young woman and queen consort who was often involved in politics, took an active interest in the care and upbringing of her children, was an ardent patron of the arts at court, and was a keen judge of character. By examining these different facets of Anna's life, an interesting and complex portrait emerges, one that paints Anna as a capable and intelligent woman in a time and place that was still not fully ready to accept one, even after the mostly successful reign of Queen Elizabeth I and the intellectual achievements of Henry VIII's final queen consort, Katherine Parr. Anna was complicated, and consequently any thorough examination of her is going to require that historians look at her through a variety of lenses and via multiple aspects of her life and career.

In the past twenty years there has been an increase in the amount of scholarship that has been produced about Anna and her time as queen. While there is still very little known about her childhood, historians have been slowly piecing together a narrative of her time as queen consort in both Scotland and England. Unfortunately, as of yet there have only been two biographies written about Anna: Anne of Denmark: Wife of James VI of Scotland, James I of England by Ethel Carleton Williams, which was published in 
1970, and Anna of Denmark, Queen of England: A Cultural Biography by Leeds J.

Barroll, which was published in $2001 .^{1}$ The work by Williams was remarkable at the time because of the sheer lack of available material about Anna and her life. By using a wide variety of primary sources and by piecing together evidence from secondary sources that focused on Anna's husband or children, Williams was able to prepare a monograph that established a basic narrative of Anna's life. This work was also important because it was one of the earliest to identify Anna as an historical figure with any sort of personal agency or importance to the greater world of Early Modern English history. The great weakness of Williams' work is that her analysis is sometimes undermined by assertions that are based on anachronistic understandings of Anna's situation and the world around her. While Williams effectively establishes a reasonable outline of who Anna was, she often makes assumptions about what Anna was thinking or feeling that she cannot possibly verify. The book has merit, but only when read with care and attention to its flaws.

The biography by Leeds J. Barroll, despite being published fairly recently, is considerably weaker. He makes the same mistake that Williams does: he makes assumptions and assertions regarding Anna that he cannot possibly verify and for which he cannot even provide reasonable evidence. He ignores Anna's childhood completely (a mistake, given the cultural atmosphere in Denmark), spends very little time focusing on her time in Scotland, and devotes most of the text not to discussing Anna's cultural contributions as a whole, but to the court masque alone. There is little focus on Anna's

\footnotetext{
${ }^{1}$ Leeds J. Barroll, Anna of Denmark, Queen of England: A Cultural Biography (Philadelphia: University of Pennsylvania Press, 2001); Ethel Carleton Williams, Anne of Denmark: Wife of James VI of Scotland, James I of England (London: Longmans Group, 1970).
} 
relationship to her husband or children (with the exception of her relationship to Henry, whom it would have been difficult to exclude, since he was heir to the throne) as they related to her cultural enterprises, and there is a plethora of factual errors. ${ }^{2}$ The one great redeeming factor in Barroll's work is, in fact, his extensive study of the masque. Though flawed, there is enough there that can be gleaned (with careful fact-checking), to warrant reading through an otherwise ponderous work.

Perhaps the best source regarding Anna's marriage and her early years with James is a book written by David Stevenson titled Scotland's Last Royal Wedding: the Marriage of James VI and Anne of Denmark (1997). ${ }^{3}$ While Stevenson's narrative is less scholarly than other works written on this era, and is marked by colorful commentary and side notes that seem to be more like gossip than history, there are sections of his work that are based entirely on primary sources (with his own commentary inserted into the narrative). It takes patience to work through this monograph, but it is worth it because of the extensive work that Stevenson has done with primary sources. This book also includes a translation of the Danish sources regarding the wedding that was done by Peter Graves, which provides another valuable primary source. This translation is particularly useful because it is more difficult to find translations of the Danish sources than it is to find the Scottish or England sources.

Anna's work with the court masque and the greater world of Early Modern English culture is the one area of her life that has received a reasonable amount of study.

\footnotetext{
${ }^{2}$ There has been an excellent review written of Barroll's book that makes many of these same points, as well as quite a few others that are equally valid: Maureen M. Meikle and Leeds Barroll, "Review of Anna of Denmark, Queen of England: A Cultural Biography,” The Sixteenth Century Journal, 34, no. 3, (2003): 920-921.

${ }^{3}$ David Stevenson, Scotland's Last Royal Wedding: The Marriage of James VI and Anne of Denmark (Edinburgh: John Donald, 1997).
} 
Clare McManus, a professor of English and Creative Writing at the University of Roehampton in London, has written several articles on the subject, along with one book on Anna and the Stuart court culture, Women on the Renaissance Stage: Anna of Denmark and Female Masquing in the Stuart Court (1590-1619) (2002), and has edited another, Culture at the Courts of the Stuart Queens (2003). ${ }^{4}$ The work done by McManus has been useful when exploring the role of women in the arts during the Stuart era, and does an effective job of exploring Anna's role not only in the theater, but also in the other arts as well. The one potential problem with McManus's work is that she occasionally bases her arguments on modern understandings of feminism, which are, of course, anachronistic. Also, her analysis sometimes feels like it is stretching the boundaries of what can reasonably be deduced from the available primary sources.

Culture at the Courts of the Stuart Queens, however, is an excellent collection of essays edited by McManus. One in particular, written by Mara R. Wade (professor of Germanic Languages and Literatures, Comparative and World Literature, and Gender and Women's Studies at the University of Illinois at Urbana-Champaign), explores the effect that Anna's upbringing in Denmark would have had on the future queen. Her essay, titled “The Queen's Courts: Anna of Denmark and Her Royal Sisters - Cultural Agency at Four Northern European Courts in the Sixteenth and Seventeenth Centuries." This essay looks at the effect that Anna and her four sisters had on the broader world of European theater

\footnotetext{
${ }^{4}$ Clare McManus, Women on the Renaissance Stage: Anna of Denmark and Female Masquing in the Stuart Court (1590-1619) (Manchester: Manchester University Press, 2002); Clare McManus, Women and Culture at the Courts of the Stuart Queens (New York: Palgrave Macmillan, 2003).

${ }^{5}$ Mara R. Wade, “The Queen's Courts: Anna of Denmark and Her Royal Sisters - Cultural Agency at Four Northern European Courts in the Sixteenth and Seventeenth Centuries," in Women and Culture at the Courts of the Stuart Queens, ed. Clare McManus, 49-80.
} 
and culture and how their upbringing and their continued relationship with their brother, King Christian IV of Denmark, played into their cultural agency.

When it comes to trying to piece together a broader understanding of Anna as a wife and mother, it has proven useful to look at biographies and other monographs about her family, and particularly about her husband, James. G.P.V. Akrigg, who was employed as a professor of English at the University of British Columbia before his death in 2001, worked extensively with King James VI/I. He not only edited a collection of the Stuart king's letters, but also wrote a biography of James titled Jacobean Pageant; Or, The Court of King James I (1967). ${ }^{6}$ Although Akrigg does not mention Anna much in his narrative, his work provides an outline of what was going on in Scotland and England during the reign of James. He also provides a rich bibliography that establishes a solid starting point for studying Anna as well.

Although there have been more monographs written about Anna's younger son, Charles, than about her elder son, Henry, historians seem reluctant to include her in the discussions about Charles. On the other hand, Anna is more often featured in scholarship that discusses Henry. This is possibly because of the intense battle Anna fought to gain custody of her son, or possibly because Anna's influence (particularly regarding the arts) is seen more clearly with Henry. Although he does not devote much time to it in his work, Roy C. Strong (a scholar of art and history of the Tudor and Stuart courts) does make a note of Anna's influence in his book about Henry titled Henry, Prince of Wales

\footnotetext{
${ }^{6}$ G.P.V. Akrigg, Jacobean Pageant; Or, The Court of King James I (Cambridge, MA: Harvard University
} Press, 1962). 
and England's Lost Renaissance (1986). ${ }^{7}$ Although the references to Anna are brief, they make valid points about the influence she had on her son, such as his love of the arts.

To understand Anna's position when she arrived in England in 1603, it is necessary to understand the position of women in general at this time in England, as well as what was expected of a queen consort. During this period, there was a shift in the ways in which women, particularly noblewomen, were educated. During the Elizabethan age, there had been a flourishing of humanist education for women, including Elizabeth herself and her half-sister, Mary. A humanist education for women, which was already being encouraged by several humanist scholars such as Sir Thomas Elyot, came into fashion after King Henry VIII (along with input from his first and last wives) insisted on a complete and thorough humanist education not only for his sons (the illegitimate Henry Fitzeroy, Duke of Richmond, and Prince Edward), but also for his daughter, Elizabeth. Several other noble families followed suit, including the houses of Grey, Seymour, Howard, and Fitzalan. ${ }^{8}$

There is very little known about the type of education Anna received during her childhood in Denmark, but according to Mara R. Wade it has generally been assumed that Anna and her sisters would have received the thorough instruction necessary to prepare them to take on the role of wife to a prominent husband. Wade postulates that Anna's education may have been similar, although certainly not identical, to the education received by her brother Christian, who was the heir to the Danish throne. She

\footnotetext{
7 Roy C. Strong, Henry, Prince of Wales and England's Lost Renaissance (New York: Thames and Hudson, 1986).

${ }^{8}$ Retha M. Warnicke, Women of the Renaissance and Reformation (Westport; London: Greenwood Press, 1983), 92-93.
} 
cites similarities in the style, structure, and language used in letters written by both Anna and her brother to support this idea. ${ }^{9}$

While there are some comparisons to be made between the courts of Elizabeth and Anna, it is crucial to remember that Elizabeth was a queen regnant while Anna was a queen consort, and therefore their relative power and position was inherently different. Elizabeth, as a queen regnant as opposed to a queen consort, had the power of the English throne was invested solely in her, and in no man. Therefore, Elizabeth wielded far more power than Anna ever would, and parliament and her council worked with her rather than with a male monarch. Elizabeth in particular made an effort to assert herself as a figure of masculine authority in the body of a woman, and faced a constant internal and external struggle over how to fill the role of a king while still maintaining the queenly qualities of a wife and mother. ${ }^{10}$ Anna would face her own challenges, but she was not in the same position of Elizabeth. She did not have to fill the roles of wife and mother symbolically because she was actually a wife and mother.

In addition to the secondary sources, there are many primary sources that have proven useful to understanding who Anna was and what role she played in the Scottish and English courts. Unfortunately, there are nearly no surviving documents written by Anna herself, save for a few letters. Consequently, it has been necessary to look at a variety of other primary sources and draw information about Anna and about the court culture from them. Several collections of letters have been published from this era,

\footnotetext{
${ }^{9}$ Mara R. Wade, "Anna of Denmark and her Royal Sisters," in Women and Culture at the Courts of the Stuart Queens, ed. Clare McManus, 53-54.

${ }^{10}$ Rayne Allinson, Liz Oakley-Brown and Louise J. Wilkinson, eds., The Rituals and Rhetoric of Queenship (Dublin; Portland: Four Courts Press, 2009), 132-133.
} 
including one edited by G.P.V Akrigg that contains the letters of James. ${ }^{11}$ The book contains letters written by and to James during his reign as king in both Scotland and England, a span of fifty-eight years. Consequently, this book does not contain every piece of correspondence relating to James, and those that have been included were chosen by the editor. Akrigg's biography of King James (as referenced previously) takes a clearly positivist view of the king, and this same bias is seen, perhaps more subtly, in this collection. In fact, there are only a few letters in the collection that were written directly to the queen, and even fewer that make any other mention of her. For the sake of studying Anna, it was helpful to put aside Akrigg's commentary for the most part, and focus solely on the letters themselves. While James himself was always careful to be studiously proper in his letters, there were still hints of his frustration and irritation with Anna present in the text. By studying the shifts in the language that James used in the letters he wrote to his wife, it is possible to begin tracing the breakdown in communication between the pair. This collection was also particularly valuable when studying the custody battle between Anna and James for Prince Henry. By looking at a series of letters written by James to Anna, the Earl of Mar, and other Scottish nobles on the subject, a narrative emerges that helps explain how Anna regained custody of her eldest son. ${ }^{12}$ A collection of letters written to and by Arbella Stuart ${ }^{13}$ was used to study how Anna interacted with and advocated for her noblewomen. Like the book of letters edited by Akrigg, this collection of Arbella's letters also features commentary by its editor, Sara

\footnotetext{
${ }^{11}$ G.P.V. Akrigg, ed., Letters of King James VI \& I (Berkeley, CA: University of California Press, 1984).

${ }^{12}$ Of course, there is no way of knowing what letters Akrigg chose to omit; this thesis can only consider those that Akrigg included.

${ }^{13}$ Lady Arbella Stuart, Sara Jayne Steen, ed., The Letters of Lady Arbella Stuart (Oxford: Oxford University Press, 1994).
} 
Jayne Steen. Steen's biases, however, are far less pronounced in her book than Akrigg's are in his. While she certainly attempts to put forth a more positive than negative image of Arbella, she is also careful to point out where Arbella made mistakes and how those mistakes accumulated and led to her downfall. Once again, there are few examples of letters that relate directly to Anna, but the few that are included in this book are worth examination. Arbella had an interesting relationship with the queen: while she often derided what she perceived to be a lack of maturity and intelligence in the queen, she also appreciated Anna's courtly manners and regal bearing, and it was to Anna that she turned when her life began spiraling out of control. Arbella's letters are part of a greater narrative thread that exemplifies Anna's advocacy for her ladies-in-waiting.

Two books of letters written by John Chamberlain, an English courtier, include a variety of letters written to various other courtiers that provides a surprisingly blunt look at English court society. ${ }^{14}$ One book contains selections from John Chamberlain's correspondence, while the other is a complete collection of his surviving letters. Chamberlain was a lesser nobleman, and consequently his letters were not subjected to the same degree of scrutiny by his contemporaries as those written by James or even Arbella. Consequently, he often voiced opinions that may not have been acceptable for a higher profile noble to express. These books contain far less commentary than those that feature the letters of James or Arbella, and instead rely almost entirely on the contents of the letters themselves. While this means that there is no context provided for the letters, it also cuts down on potential bias from an editor. While the editors may have been

\footnotetext{
14 John Chamberlain, Elizabeth McClure Thomson, ed., The Chamberlain Letters: A Selection of the Letters of John Chamberlain Concerning Life in England from 1597-1626 (Toronto: Capricorn Books, 1966); John Chamberlain, N.E McClure, ed., The Letters of John Chamberlain, 3 Vols. (Philadelphia: American Philosophical Society, 1939).
} 
selective in determining which letters to include, it is of course impossible to analyze the resulting silence that comes from omitting letters. Bias from Chamberlain himself, however, is still present: the content of some of his letters reads more like gossip than a historical record. Sometimes this newsy approach to the English court is valuable to scholars because it lacks the pretension and self-censorship practiced by the royal family and those close to them. One such example of this is Chamberlain's observations regarding the impending wedding between Princess Elizabeth Stuart and Count Frederick V. As will be seen, Chamberlain's observations were much in line with Anna's own opinions about the match.

Only one diary written by a woman was available for study, but The Diary of the Lady Anne Clifford ${ }^{15}$ provided a fair amount of detail about Anna's initial entry into England, and was even more useful for its account of Anna's intervention on behalf of Lady Anne when it came to a settlement of Lady Anne's inheritance. Lady Anne's diary is written in a concise style, but one that captures the most important details: all of the significant events in Lady Anne's life were recorded faithfully, including her first introduction to Anna and the queen's role in Lady Anne's inheritance settlement. Lady Anne's diary occasionally uses the same conversational tone that Chamberlain's letters do, possibly because she never intended for the contents of the diary to be published, and therefore did not feel the need to exercise the same discretion that she may have otherwise used.

The Calendars of State Papers were also invaluable for their concise and relatively straightforward account of the comings and going at court. Several different calendars

\footnotetext{
${ }^{15}$ Lady Anne Clifford, Isabella Barrios, ed., Vita Sackville West, introduction, The Diary of the Lady Anne Clifford, 1590-1676 (Boulder, CO: Aardvark Press, 1997).
} 
were used for this thesis: the Cecil papers from Hatfield House, the traditional Calendar of State Papers Domestic, and the Calendar of State Papers Venetian, which is a collection of documents in the archives of Venice that relate to affairs in England. The calendars are fairly straightforward: the editions used for this thesis lacked any commentary on the part of the editors. The volumes are also nearly or entirely complete, which indicates that the editors were not responsible for cutting or adding material to support a bias or agenda. Of course, the Venetian ambassador, who wrote the actual entries calendared here, may have been biased in his observations; additionally, the author or editor of the Calendar itself may have introduced biases in the summaries of these papers for this Calendar.

In particular, the domestic calendar entries for the years 1611-1618 was useful for their detailing of the events relating to the rise and fall of Robert Carr, and the trial of Carr and his wife, the Lady Francis Howard, for the death of Thomas Overbury, a series of events that involved Anna to some extent. The calendar refers to a theoretically complete series of state documents that trace the affair from the first suspicions about Carr and Howard to the final sentencing of the pair and, later, the commuting of their sentences. The drawback to these documents is that they lack the human element found in other sources like the Chamberlain letters. Used together, however, the state papers and the personal letters and diaries of noblemen and women during this time establish a fuller picture of the early modern English court as it would have been experienced by Anna. The calendar of the Venetian papers tended to include more information about the court weddings and marriage negotiations than about other aspects of the reign of James VI/I or of Anna. Whether it was Prince Henry or Princess Elizabeth, the Venetian ambassadors 
were always keenly interested in the potential mates for the English royal children.

Unlike their English counterparts, the Venetian calendars were more inclined to use an informal or conversational tone, which made it necessary to cross reference the events detailed in these papers with other sources to establish a reliable context. ${ }^{16}$

Perhaps the most valuable mine of primary sources for the purposes of this thesis are those that relate to the court masques and Anna's participation in them. The two main writers employed by Anna were Ben Jonson and Samuel Daniel, and fortunately, almost all of their works have been preserved with the original notes. The court masque is probably the best source for understanding Anna's identity, both political and personal. Studying the court masque is important because it was one of the few forums Anna had in which to express herself relatively openly. Notes written by Jonson and Daniel about how Anna influenced costume, plot, and cast add to the modern understanding of who she was and how she used the court masque to express her personal agency. Both writers also included post-performance notes about how the show was received by the court, which provides valuable insight into court attitudes not only towards the court masque, but towards Anna herself and the changing status of women that was unfolding on the Renaissance stage.

For the purpose of this study, each masque in which Anna participated was studied in regards to its content, and particularly the roles that Anna chose to play in them. From this information, it was possible to compile a reasonable picture of not only

\footnotetext{
${ }^{16}$ British History Online, Calendar of the Cecil Papers in Hatfield House, Volume 16: 1604, last date updated: 2011, < http://www.british-history.ac.uk/report.aspx?compid=112201>; Mary Anne Everett Green, ed., Calendar of State Papers, Domestic Series, of the Reign of James I. 1611-1618, Preserved in the State Department of Her Majesty's Public Record Office (Nendeln [Liechtenstein]: Kraus Reprint Ltd., 1967); British History Online, Calendar of State Papers Relating to English Affairs in the Archives of Venice, Volume 12 - 1610-1613, last date updated: 2011, < http://www.britishhistory.ac.uk/source.aspx?pubid=1011>.
} 
who the queen was, but how she perceived herself and how she wanted to be perceived by the nobility who made up the masque audience. Following Anna's masquing career through these documents is one of the most useful ways to trace her changing interests and ideas, and is perhaps the closest that scholars can get to establishing Anna's voice.

So what is known about Anna of Denmark? What was her personality like? What were her interests? How did her contemporaries perceive her? The few historians and biographers who have focused on Anna have been able to piece together a fairly complete picture of the young queen, her upbringing, and her physical and intangible qualities. Understanding these aspects of Anna's early life is crucial to understanding her later actions and how her intellect and demeanor developed to create the queen she would become.

Anna was born in Denmark on 12 December 1574. She is described as having been a very pretty, even beautiful young woman, and the portraits painted of her and her older sister, Elizabeth, would seem to attest to that assessment. ${ }^{17}$ Naturally, court portraiture was designed to flatter and enhance the best features, but some of Anna's actions as queen indicate that she considered herself to be at least reasonably attractive. During her first progress into England, she insisted on allowing herself to be seen by the people and to see them as well, a throwback to the days of her predecessor, Elizabeth. Anna gave the English people something to look at and admire; something that her husband never had a talent for doing. Although she could hardly take the credit for her natural beauty, Anna certainly understood how to use it, as is evidenced by her public appearances and her participation in the spectacle of the court masque.

\footnotetext{
${ }^{17}$ Williams, Anne of Denmark, 9.
} 
What of Anna's less tangible qualities? Williams' biography of Anna notes that Anna had great strength of character, was courageous in the face of a strange land and ambitious courtiers, was fiercely loyal to her friends and her family, and was fairly affable and well-liked by her subjects. In a gesture of good will, Anna even made the effort to learn Broad Scots so that she would blend in with her new subjects with more ease. ${ }^{18}$ She also loved to dance, and enjoyed fine clothes and beautiful jewels, the latter of which is attested to by the extensive records of her personal jeweler, George Herriot. ${ }^{19}$ All of these could be perceived as wonderful qualities, but none of them, with the possible exception of Anna's learning of Broad Scots, speaks to the Danish queen's intellect. In fact, Anna was in many ways the ideal Renaissance woman described by Baldassare Castiglione in his work The Book of the Courtier. In the book, the character of Giuliano Medici extols the virtues of women, stating that throughout history women have successfully waged wars and ruled kingdoms. Giuliano goes on to praise women as being of keener mind than men, and just as virtuous:

In case you wil then consider the auntient Histories (albeit men at all times have bine verie sparing in writinge the prayses of women) and them of latter dayes, ye shall finde that continually vertue hath raigned aswell emong women as men: and that suche there have bine also that have made warr and obteined glorious victories, governed realmes with greate wisdome and justice, and done what ever men have done. ${ }^{20}$

When dealing with Anna, then, it is the historian's job to take all of these intangible qualities, as well as her beauty, and examine how Anna applied them during her time as queen consort to James.

\footnotetext{
${ }^{18}$ Wade, "Anna of Denmark and Her Royal Sisters," 56.

${ }^{19}$ Archibald Constable, Walter Balcanquhall, Anne, Robert Johnston, and George Heriot, "Extracts from Accounts and Vouchers Relative to Jewels Furnished by George Heriot to Anne of Denmark" (Edinburgh: Printed for Archibald Constable, 1822).

${ }^{20}$ Baldassare Castiglione, The Book of the Courtier (London: David Nutt in the Strand, 1900), 224-225.
} 
Of course, in order to understand how Anna would exercise these qualities, it is essential to understand how she came by them in the first place. This leads to a brief examination of Anna's family and her life in Denmark. In particular, Anna's mother Sophie and her brother Christian, who would later become King Christian IV of Denmark, would play significant roles in her life. Anna was the second eldest child of King Frederick II, king of Denmark and Norway, and his queen consort Sophia, the daughter of Ulric III, duke of Mecklenberg. The sources on Anna say little about her relationship with Frederick, and indeed it is entirely possible that, given the period, the father and daughter would have had little interaction with each other. Frederick did, however, have a great love of learning and intellectual pursuits. He was a generous and frequent patron of the famous astronomer Tycho Brahe, who is credited with discovering a major nova in the constellation of Cassiopeia in 1572, and whose observational data is thought to have laid the necessary groundwork for Isaac Newton's later work. It was King Frederick II who funded Brahe's castle-laboratory Uraniborg on the island of Hven. $^{21}$

Queen Sophia was another matter entirely. Twenty-three years younger than her husband, she married Frederick on 20 July 1572 when she was just fourteen. To all appearances (and despite Frederick's alleged infidelities), the couple seems to have had a decent, if not loving, relationship. Sophia, deciding that court life was not suitable for young children, sent Elizabeth, Anna, and later Christian to be raised by their maternal grandparents until they reached their teens. Consequently, Anna lacked the direct physical presence of a father during her formative years. It is difficult to say how this

\footnotetext{
${ }^{21}$ Barroll, Anna of Denmark, 14-16.
} 
affected her later on, although it is possible that she might have been more inclined towards the scientific and theological intellectual pursuits that James himself favored. Although she was not directly involved in their early lives, Sophia continued to take a great interest in her children and their care and education. After the death of her husband on 4 April 1588, she was made the trustee (although never the regent) of her son Christian's interests in the duchies (since he was still a minor at the time), and she used this position to secure land and titles for her younger sons, as well as suitable dowries for her daughters. ${ }^{22}$ Sophia was a great lover of knowledge, and was a highly gifted woman in her own right. She supported Brahe (who happened to be the son of her mistress of the wardrobe) along with her husband, and it was she who successfully lobbied for Brahe to have the right of appointment of succession at Uraniborg. This was an important marker for any Danish subject: thanks to Sophia's intervention, Brahe would be able to decide who would gain possession of the castle and laboratory at Uraniborg, where he lived and worked, instead of it passing to the crown upon his death. ${ }^{23}$

Perhaps even more significantly, Sophia was very active politically, especially after the death of her husband. She managed to acquire large dowries and a significant sum of money for the weddings of Elizabeth and Anna, and she fought, albeit unsuccessfully, to gain the regency in Christian's minority. Following an unsuccessful attempt to divide up the duchies of Schleswig and Holstein to provide lands for her

\footnotetext{
${ }^{22}$ Wade, "Anna of Denmark and Her Royal Sisters," 53. Sophia's political activism was not necessarily appreciated by the Danish council: in 1593 they held a special vote to have Christian declared of age (he was fifteen at the time) so that he could take control of the country from Sophia. Sophia retired to her widow's seat of Nykøbing, where she not only restored the castle, but also established a successful stud farm that traded with the rest of Northern Europe. She was so adept at managing her business and other affairs that, when she died, she was able to leave sizeable bequests to her surviving children.

${ }^{23}$ Barroll, Anna of Denmark, 16. For more information about Tycho Brahe see: J.R Christianson, "The Legacy of Tycho Brahe," Centaurus 44 (2002): 228-247.
} 
children, Sophia moved to the Castle Nykøbing on the island of Falster, where she built a magnificent castle and continued to receive foreign ambassadors and hold some degree of political influence. She became incredibly wealthy and was able to make two large loans to her son Christian in 1625, during the Thirty Years' War, and again in 1627. When Sophia died on 14 October 1631 at the age of seventy-four, she was the wealthiest woman in Denmark and had outlived her daughter Anna by twelve years. ${ }^{24}$

So what did Anna learn from her mother, who seems to have been a strong and pragmatic character? It is probable that Anna learned a great deal simply from watching her mother, even from a distance. Sophia was never given power outright, just as Anna never would be granted direct power. Instead, Sophia had to learn to work through various channels and connections to exercise authority and power, even after her husband died. Anna would also develop this ability, as will be seen in the sections dealing with her life, particularly in Scotland but also in England.

Anna's relationships with her siblings would also have an affect on the development of her personality and intellect. She had one elder sister, Elizabeth, and six younger brothers and sisters: Christian, Ulrik, John August, Augusta, Hedwig, and Johan. Several of her siblings would go on to make respectable marriages, and of course Christian would inherit his father's throne, but only Anna would ever be made a queen. Anna seems to have had a close relationship with her older sister, which is perhaps not surprising given how much time they spent together growing up under the care of their maternal grandparents. ${ }^{25}$ Anna was also very close with her brother Christian, who came

\footnotetext{
${ }^{24}$ Ibid., 16.

${ }^{25}$ RoyaList Online, "Family Tree for Anne of Denmark (Wife of King James I of England)," date accessed: 17 Apr. 2012, < http://www.royalist.info/execute/tree?person=265>. In Denmark, tradition dictated that the
} 
to visit her several times while she resided in England. It is important to remember that Anna's heritage gave her some degree of royal protection and status: she was not only the queen consort of a king, but also the daughter, sister, and mother of kings.

Eventually, Anna was deemed eligible for marriage, and King Frederick began considering potential matches for both Anna and her elder sister, Elizabeth. King James of Scotland was one of those potential matches. Due to a series of misunderstandings and slights between the Danes and the Scots during the initial marriage negotiations, however, the wedding between James and Anna almost did not happen. Even after this initial hurdle had been overcome, there were multiple delays on the part of both the Scots and the Danes, although the Danes were less responsible for the delays than were the Scots. Here it is useful to look once again to the work of David Stevenson who, although occasionally less than objective and hardly complimentary to Anna, has compiled a reasonable account of the marriage negotiations and proceedings.

The negotiations for a Danish bride for James were almost over before they even began. Denmark had sent two ambassadors, Manderup Parsberg and Henrik Below, with their secretary Dr. Nicholaus Theophilus, to Scotland ostensibly to negotiate the return of the isles of Orkney and Shetland, which Denmark had ceded some years earlier as part of another dowry for Queen Margaret, a previous Danish princess that had been married to a Scottish king. True to their mission, the Danes never once spoke of marriage negotiations, but there were many at the court that made that assumption, and seemed to approve of the match. The Danes, however, were not impressed by their treatment at the

next monarch be elected rather than appointed or granted the title via inheritance; however, it was fairly common for the previous monarch's eldest son to be elected even if, as was the case with Christian IV, the son was still in his minority. 
Scottish court, due to the rise in power of James Stewart, Earl of Arran, James VI/I's uncle and a strong and vocal supporter of Denmark's traditional nemesis Sweden. ${ }^{26}$

Fortunately for all those involved in the matchmaking process, the Earl of Arran was eventually deposed, James VI/I quickly made an effort to mend fences with Denmark, and the Danes once again warmed to the idea of a Scottish match. This was by no means the end of the story, however. For one thing, James was still seriously considering a match with Catherine de Bourbon, the sister of the wealthy Henry III, King of Navarre and heir to the throne of France. Ultimately, this match was discarded because James feared that when Henry III did ascend the French throne, and should James realize his hopes of ascending the English throne, then he would be drawn into France's wars of religion. Denmark, while Protestant like Navarre, had a history of avoiding the religious wars of Europe, making it a more attractive match. ${ }^{27}$ It is interesting that this would have been a very similar situation to what the Danes themselves were facing from their perspective: if Anna was married off to James they were essentially gambling that James would in fact succeed to a more powerful European throne, in this case the English throne. They were also risking potential involvement in continental wars if James, like his great uncle Henry VIII or even to some extent his mother's cousin Elizabeth, made it a habit to be involved in battle constantly.

Throwing a wrench even further into the works was James' own mother, Mary Queen of Scots, who was still very much alive when the marriage negotiations began, although she would be beheaded before the marriage took place. Mary had her own thoughts when it came to the marriage of her only child. Although she had desired a

\footnotetext{
${ }^{26}$ Stevenson, Scotland's Last Royal Wedding, 5.

${ }^{27}$ Ibid., 11-12.
} 
Spanish (read: Catholic) match for her son, she was well aware that her cousin, Elizabeth, would never allow it to take place. Mary also had come to the conclusion that, despite being Protestant, the Danes' Lutheranism was less offensive than the Church of England or the Calvinist Scots' Presbyterianism. She even considered asking Elizabeth to encourage James in the Danish match, but wisely decided against doing so. In his book, Stevenson maintains that, touchy as Elizabeth was about the subject of her death and succession, any approach made by her arch-rival regarding a marriage involving the most likely candidate for the succession would have been met with (at least) distaste and resentment. $^{28}$

It is probable that Mary, despite having sacrificed her throne, her kingdom, and even her son in pursuit of her love interests, was not a stupid woman: impetuous, perhaps, but not stupid. She may have still hoped for a reprieve from Elizabeth, but at this point she probably also recognized that her son was her best hope for freedom, assuming he successfully ascended to the English throne. By staying out of the proceedings, she gave James the best possible chance at making a successful Protestant marriage and someday achieving that which she herself could not achieve.

Then, there was the debate over whether James should be offered to Anna or her older sister, Elizabeth, as a husband. James and his Scottish advisors took so long in their replies that by the time they finally agreed to a Danish marriage , Elizabeth was already betrothed, and James was insisting that Scottish kings only married eldest daughters. Eventually, due in part to Sophia's intervention and insistence that they had saved the

${ }^{28}$ Ibid., 3-4. 
more beautiful daughter for James, in July 1589 he agreed to marry Anna instead. ${ }^{29}$ This should hardly be seen as much of a concession on James' part: he had not yet ascended to the English throne, and there was still no ironclad guarantee that he ever would. James and Scotland were still not a powerhouse in the greater European scheme, and he therefore had little room to complain about marrying a second daughter. Furthermore, if the portraiture is any indication, then Anna was at least as beautiful as her elder sister, if not more so, and she had certainly been raised under the same social, intellectual, and courtly conditions.

Both parties eventually agreed on the terms of the marriage, with Queen Sophia negotiating as regent in place of King Christian IV, who was still in his minority. James was to be given Anna's dowry of 75,000 thalers or 100,000 florins, and Anna was to receive from James the castles of Linlithgow and Falkland, as well as one third of the taxes on the property of Scotland. A wedding by proxy took place in Denmark on 19 August 1589, with George Keith, the Earl Marischal, standing in as James' proxy. There was a ceremonial and symbolic "mounting" of the bed, ${ }^{30}$ and then preparations began for Anna to travel to Scotland. ${ }^{31}$ There is nothing recorded about Anna's thoughts or feelings during these proceedings, and it is impossible for a modern historian to assess accurately Anna's reactions to her marriage and impending move. She was a fifteen-year-old girl who was about to leave the only life she had ever known, and whatever her hopes and

\footnotetext{
${ }^{29}$ Ibid., 11 and 14.

${ }^{30}$ This mounting ceremony consisted of Anna and the Earl, in the presence of witnesses, sitting side by side on a "marriage bed."

${ }^{31}$ Peter Graves, "The Danish Account," in Scotland's Last Royal Wedding: The Marriage of James VI and Anne of Denmark by David Stevenson (Edinburgh: John Donald, 1997), 79-85. This translation of the Danish account is included in Stevenson's book as a complement to the Scottish history.
} 
aspirations for the future, they cannot have been much helped by the events that would take place over the next few months.

Anna's journey to Scotland was beset with problems from the start. Initially scheduled to depart on the 1 September 1589; Anna did not in fact leave until the fifth, accompanied by a delegation including Admiral Peder Munk, who was charged with leading the mission, Breide Ranzau, and Dr. Paul Kniblo. Despite the prowess of the Danish naval fleet, the storms of autumn and winter were overwhelming. Contrary winds prevented the fleet from making any real progress, and at one point the ship with Anna on it went missing for two days. On the 24 September 1589 , James ordered a day of fasting and prayer for the safety of his new bride. The Danes were by that time quite stuck in Norway, from where they had tried unsuccessfully to depart a total of four times, with Anna apparently becoming seasick on the fourth attempt. The Danish ships were in desperate need of repair, and no one wanted to jeopardize the princess' life. Anna and her ambassadors wished to return to Denmark; the Earl Marischal wanted Anna to go on to Oslo and wait out the storms there. It was eventually agreed that Anna would remain in Oslo for the time being and then possibly return to Denmark. In any case, the journey to Scotland would be abandoned until after the winter storm season had passed. ${ }^{32}$

At this point, it is not reasonable to assume that Anna had any particular qualms about her marriage or that she had capriciously changed her mind about the whole affair, and that this was why she wanted to return to Denmark rather than continue her journey to Scotland. She was simply exhausted by the fifty days she had spent on storm-tossed seas, and assumed (correctly) that it would be more feasible to return to Demark by land

\footnotetext{
${ }^{32}$ Ibid., 86-88.
} 
than to make another attempt at the sea voyage or spend the next few months in Norway which, although controlled by the Danes, was not a place with which Anna was overly familiar. Of course, her feelings or motivations are irrelevant. Given that it is her male chaperones' names that are mentioned most frequently in Peter Graves' translation of the Danish account of the marriage, it seems unlikely that she had much say in the matter regardless of what she would have thought or felt.

There was a second, even less savory consequence of the storms that kept Anna and James apart. When the mission to deliver Anna safely to Scotland failed in spectacular fashion, someone had to shoulder the blame. First on the list was Admiral Peder Munk, who had been put in charge of the Danish fleet and given responsibility for the mission and who was therefore also held responsible for its failure. Munk, however, seems to have had a healthy sense of self-preservation, and was able to shift the blame away from himself and onto Christofer Valkendorf, the governor and treasurer of Copenhagen. Valkendorf had been the man put in charge of supervising the repairs and maintenance of the Danish ships and had clearly, according to Munk, been negligent in his duties by allowing unseaworthy ships to carry Anna and her entourage out into the stormy Baltic seas. Valkendorf was tried for his negligence, but he also placed the blame elsewhere: on witchcraft. Sure enough, Valkendorf was declared innocent, and a series of people whom he had named were executed as witches. ${ }^{33}$ There was also a series of witchcraft trials in Scotland that actually worked out quite neatly for James, as the

\footnotetext{
${ }^{33}$ Stevenson, Scotland's Last Royal Wedding, 72-73.
} 
Scottish witches claimed that the devil had named James as his greatest enemy, therefore making James the epitome of goodness and holiness on earth. ${ }^{34}$

Having finally made the decision to marry Anna, James wanted to meet his new bride as soon as possible, and the delays were becoming increasingly intolerable. Stevenson suggests that during this brief period in time, after James had agreed to the marriage but before he had actually met Anna, he was genuinely in love with the Danish princess. ${ }^{35}$ This could simply be romanticizing on the part of Stevenson, but James' own letters seem to indicate at least a degree of interest in his future bride, if not necessarily love. In a letter addressed to the people of Scotland, James wrote:

The word, then, coming to me that she [Anna] was stayed from coming through the contrarious tempests of winds and that her ships were not able to perfect their journey this year through the great hurt they had received .... I, upon the instant, yea the very moment, resolved to make possible on my part that which was impossible on hers. ${ }^{36}$

Alleged romantic ardor was not the only concern on James' mind, as can be seen from that same letter, where he addresses rumors about his commitment to the marriage:

Yea, my long delay bred in the breasts of many a great jealousy [suspicion] of my inability, as if I were a barren stock. These reasons and innumerable others, hourly objected, moved me to hasten the treaty of my marriage; for, as to my own nature, God is my witness I could have abstained longer. ${ }^{37}$

It is interesting, and worth noting, that there were already rumors swirling around James concerning his sexual capabilities. He is quick to note here that he could have done

\footnotetext{
${ }^{34}$ Ibid., 74. There was nothing to suggest that the witchcraft trials in Denmark and those that occurred in Scotland were in any way related or connected.

${ }^{35}$ Stevenson, Scotland's Last Royal Wedding, 29.

${ }^{36}$ Akrigg, Letters of King James VI/I, 98.

${ }^{37}$ Ibid., 98.
} 
without marriage quite a bit longer, but that he felt compelled to prove his virility to his countrymen. This attitude already boded ill for his relationship with Anna, and it was certainly not the last time that James' sexual proclivities would be called into question. James reached Oslo on 19 November 1589 and set forth on land to meet Anna. Williams describes the meeting as being less than ideal, stating that Anna was taken by surprise by the Scottish king, who was perhaps less physically attractive than Anna had been led to believe, based on his portraiture and the reports of the Scottish and Danish ambassadors. When James approached Anna to kiss her, she shied away, stating that it was against Danish custom (which would have dictated a more formal, and less effusive, greeting) to kiss upon a first meeting. By the end of the meeting, however, it seems as though the couple were conversing in a friendly manner and, as James left, Anna accepted a kiss. In a further show of impatience, James insisted that the couple should be wed in a church ceremony as soon as possible, and so on 23 November 1589, James and Anna were married at St. Halvard's Church in Oslo. The couple was then invited by Anna's mother, Queen Sophie, to spend the rest of the winter in Denmark, an invitation that James readily accepted. While in Denmark, yet another wedding ceremony took place on 21 January 1590, this time in the chapel at Kronborg Castle and according to the traditional Danish Lutheran rites. ${ }^{38}$

James had made a successful marriage: he had shown both his independence and his political ambitions by making a foreign diplomatic marriage while still picking a bride that would not displease his benefactor, Queen Elizabeth. ${ }^{39}$ Anna, meanwhile, had done well for a second daughter. She was, after all, the only one of her siblings to be

\footnotetext{
${ }^{38}$ Williams, Anne of Denmark, 20-23.

${ }^{39}$ Stevenson, Scotland's Last Royal Wedding, 32.
} 
crowned a queen consort, and she had married a man who was not only a king in his own right, but who was also the most likely successor to the throne of England, a country that was steadily rising to become a major European power. In Scotland, Anna would be given the opportunity to stretch her wings and test her abilities in ways that she never would have been able to in Denmark or as the wife of a lesser nobleman. In England, Anna would do something that was rare for a queen consort: she developed her own court separate from that of her husband. An English royal court was a fluid entity that consisted of members of the gentle and noble classes who associated themselves with a monarch or, as would be the case during the reign of King James, the queen consort or the heir apparent. The court was not a physical location (although there were specific physical locations associated with each court), but rather a body of people that orbited around a royal figure. The members of the court would follow their royal figure of choice and would, theoretically, declare their loyalty and allegiance to that figure. They also had the potential to play a role in the political machinations of their chosen court. ${ }^{40}$

In the following chapters, Anna's life will be analyzed through her roles as mother, wife, patron, friend, enemy, and masquer. By studying the development of Anna's own court and her relationships with her courtiers and favorites, historians have the opportunity to look at how a queen consort was able to exercise power and influence, even when they did not have access to the same power that a king or queen regnant would have had. This is also true when looking at how Anna used the roles of royal wife and mother to further not only her own interests, but those of her children. Finally,

\footnotetext{
${ }^{40}$ Gregory Vaughn McNamara, “'A Perfect Diamond Set in Lead': Henry, Prince of Wales and the Performance of Emergent Majesty," (Unpublished PhD Dissertation, West Virginia University, 2000), 6465.
} 
studying the ways in which Anna participated in and influenced the development of the court masque provides valuable insight into how Anna developed a public person for herself, how she saw herself, and how she wanted others to see her. The intent of this thesis is to add to the current historiography not only of Anna, but also the history of queens consort in general and, even more broadly, women's history. By exploring these roles this thesis will show that the Danish queen was an interesting and complex woman worth a careful and detailed analysis. 
Chapter Two: Anna as a Royal Wife and Mother

\section{At the Scottish Court}

Anna's arrived in Scotland in early May 1590, and her first few months in Scotland were fairly positive. Although Anna was disappointed with the poor condition of her morrowing gift, the lands and castle at Dunfermline, James had done the best he could with his limited financial resources, and he had made an effort to make it as comfortable as he could for his new bride. He had even had Anna's royal bed shipped from Denmark for use in Dunfermline Palace. According to Williams, during this time in their marriage James treated Anna with "camaraderie and consideration." ${ }^{41}$ It is important to realize, however, that there were significant differences that separated Anna and James even at that early date.

Differences in upbringing and lifestyle would show up in the relationship between the pair fairly early on in the marriage. Anna had been brought up in the Danish court, and as such she expected a certain level of civility and decorum when it came to court life. $^{42}$ The Scottish court, and James himself, would have stood in sharp contrast to these expectations. James was described as being of average weight and height, with brown hair and eyes, and a square-cut beard. He had been born with a tongue a bit too large for the size of his mouth, which seemed to add thickness to his speech (although the sources do not indicate he had a particular speech impediment, as his son Charles would) and occasionally made drinking unwieldy, and he appeared to have poor muscular coordination, which caused his gait to be slightly ungainly.

\footnotetext{
${ }^{41}$ Williams, Anne of Denmark, 33-34.

${ }^{42}$ Mara R. Wade, "The Queen's Court: Anna of Denmark and her Royal Sisters" in Women and Culture at the Courts of the Stuart Queens, ed. Clare McManus, 49-50.
} 
From the outset, Anna seems to have had what could be considered a salutary affect on the Scottish court. In her biography of Anna, Williams quotes a letter written by William Dundas to Archibald Douglas:

Things are beginand to be greatly altered here; the court wondrous solitary, \& [the] patron of the Court of Denmark is greatly before [the] King's eye and [the] eye of our reformatours bie [w] hom [the] King's howse is deminised of [the] best of his ald servants... Our Quein carys a marvelus gravity, [with] her patriall solitarines, contrar to [the] humor of our pepell, hath bannised all our ladys clein from her. ${ }^{43}$

Clearly, there were some mixed feelings about the effect that Anna was having on the Scottish court, but the letter does not deny that Anna had reformed aspects of the king's court, which would imply that there were aspects that needed to be reformed in the first place. Anna cannot have hoped to reconstruct the Scottish court fully, since as a queen consort she simply did not have that much control or power, but her influence seems to have had at least some positive influence when it came to court decorum. Of course, any assessment of positive and negative aspects of a royal court are relative: the Scottish courtiers, who were already at odds with one another, did not appreciate a foreigner, and a young woman at that, coming in and trying to overhaul completely the atmosphere in their domain. Anna represented an unknown quantity in Scotland. With whom would she ally herself? Whom would she favor? How much would she influence the king? These were all questions with which the Scottish nobility would have been faced when the Danish queen arrived. Anna would meet a better reception later in England, where her courtly manners and royal demeanor were not only appreciated, but expected. With her noble yet approachable bearing, Anna was able to endear herself to

\footnotetext{
${ }^{43}$ Edmund Lodge, Illustrations of British History Vol. III (London: J. Chidley, 1838), 1-2.
} 
the English people in a way that was reminiscent of their former queen and in a way that James, who was notoriously awkward, would never be able to do.

There also seemed to be a clash of public personalities between James and Anna. James was not particularly comfortable around his subjects, and harbored a (perhaps not unreasonable) fear of assassination. Given the circumstances of his childhood, this is understandable. At the relatively young age of twenty-five, James had witnessed several murders and deaths that had badly jarred him. Even before the execution of his mother, a woman that James never really knew, he had been subjected to several plots and conspiracies within the Scottish court in the interim between Mary's abdication and the young king's majority. On 4 September 1571, when James was just five years old, the Earl of Huntley and the Hamiltons (a Catholic faction) attempted to take over parliament and kidnap the boy king. Although the attempt failed, James watched his grandfather, the Earl of Lennox, die as a result of the attack. ${ }^{44}$ On 22 August 1582, James returned from a hunting trip to find his castle surrounded by armed men. Fearing that James was being converted to Catholicism by his friend James Stewart, Earl of Arran, three Protestant lairds, the earls of Gowrie and Mar and the Master of Glamis essentially kidnapped the king and imprisoned the Earl of Arran. Although he escaped unharmed less than a year later, the experience disturbed James greatly. ${ }^{45}$

Despite the violent political situation in which James grew up and which continued in Scotland as he matured, James was still intent on becoming king not only of Scotland, but also of England. His lack of social graces and lack of a charismatic public persona would probably have hindered him (more so in England than in Scotland), but

\footnotetext{
${ }^{44}$ Akrigg, Jacobean Pageant, 7.

${ }^{45}$ Ibid., 9.
} 
not devastatingly so. These characteristics would, however, prove to be a significant issue when it came to relations with his wife. Whether James was attracted to his wife (or any woman) was ultimately irrelevant, because even if sexual attraction had existed it is unlikely he ever would have trusted her, since he had been betrayed and manipulated by many people, including members of his family.

Anna, unlike James, seemed to love being seen and interacting with her subjects. In many ways, she was filling a role that had been left empty by the death of Queen Elizabeth I. Elizabeth had worked hard to maintain her public image and present herself to the English people as someone to be looked at and admired, as well as respected. ${ }^{46}$ Of course, Anna did not face the same kind of challenges that Elizabeth did, since she was the queen consort of a male king instead of a queen regnant trying to prove to her subjects that she was capable of ruling as effectively as a male monarch (and, in particular, as effectively as Henry VIII). Elizabeth's position then was different in that she had to try to represent both a king and a queen in one body: one way in which she fulfilled the ideal of queenship was by creating a public persona with a focus on feminine beauty and motherly kindness. ${ }^{47}$ It was this role that Anna slipped into after the death of Elizabeth.

Anna and James could not have been more different in their public personas, and James would have recognized this. As concerned as he was with the public perceptions of his family (as will be explored later in this chapter), his fear of assassination outweighed any desire to make regular public appearances. Based on his actions during the custody battle over Prince Henry, it is apparent that James believed that Anna's popularity would

\footnotetext{
${ }^{46}$ Christopher Haigh, Elizabeth I (Harlow; London; New York: Longman, 2001), 179.

${ }^{47}$ Ibid., 185-187.
} 
prove to be dangerous. If Anna had been able to gain enough popular support, she would have been able to ally herself with any one of the multiple factions that were dissatisfied with the rule of James, although it seems unlikely that Anna would actually have followed this course of action. Having been raised to behave always in a manner that would befit a princess and a queen, Anna understood the benefits of remaining a faithful, albeit perhaps distant, wife to James rather than attempting to mount any type of insurrection. Whether Anna was aware of the violent history of Scotland before she arrived is unclear, but she would have been made aware of it before too long. If Anna wanted more power or control, she was not going to find it among the quarreling Scottish nobility. She would also not find it among the English nobles who had only just regained a male monarch after the death of Elizabeth, and who would pin their future hopes on Anna's son, Henry. Anna also realized that any faction with which she allied herself would have been more interested in gaining more power for themselves than sharing power with her.

James and Anna were also separated by their individual religious preferences and practices. In order to understand the kind of difficulties that Anna's religious preferences would have created in relation to James, it is important to understand the type of political and religious environment that they found when they came to England. Although it had been several decades since the upheaval of the early Reformation and the sharply contrasting religious policies of Edward VI (who reigned from 1547 to 1553) and then his half-sister, Mary I (who reigned from 1533 to 1558), England was still in a state of relative religious confusion. Beginning with Elizabeth I's reign (which began in 1558), Elizabethan Protestantism had brought with it a wide range of religious preferences and 
practices regarding piety and doctrine, and so there was little hope of any real religious cohesion, especially regarding doctrine, in England despite any monarch's best efforts. Furthermore, there was still hope on the part of the English Catholics that James, perhaps as a tribute to his deceased mother, would restore Catholicism in England. They were, of course, to be sorely disappointed. While still in Scotland, James had made promises to Anglicans, Catholics, and Puritans regarding his intentions towards them. Once he took the English throne, however, few of these promises ever came to anything. ${ }^{48}$ In an attempt to maintain toleration, James was fairly lax about anti-Catholic legislation early on, which inevitably irritated Protestants. On the other hand, he still never restored Catholicism or openly stated that Catholics could worship as they pleased, which raised the ire of the Catholics. ${ }^{49}$

James was in a tight spot when it came to religion. He had been baptized a Catholic (his mother, after all, had been Mary, Queen of Scots, a rallying figure for those English subjects who wanted a return to Catholicism), but had been raised Calvinist by the Scottish Kirk, joining the Presbyterian Church of Scotland as a young adult, and eventually joining the Church of England. ${ }^{50}$ When he became king of England, James attempted to maintain a policy of tolerance when it came to his Catholic subjects, provided that they were what he considered to be "moderate" Catholics and provided that their religious practices did not affect their loyalty to James. ${ }^{51}$ In collaboration with continental religious leaders, he tried to forge a compromise with the pope in Rome

\footnotetext{
${ }^{48}$ David Harris Willson, King James VI and I (Oxford: Alden Press, 1962), 202-204.

${ }^{49}$ Akrigg, A Jacobean Pageant, 307-308.

${ }^{50}$ Stevenson, Scotland's Last Royal Wedding, 41.

${ }^{51}$ Michael Questier, "Catholic Loyalism in early Stuart England," The English Historical Review, 123, no. 504 (2008): 1142-1143.
} 
which, although it ultimately failed, showed that James was not interested in actively prosecuting English Catholics. ${ }^{52}$ This desire to soothe religious tensions within his kingdom and his refusal to prosecute actively religious dissidents was characteristic of James, who promoted himself as a unifying king. It follows that, since James was interested in avoiding war in Europe and was even reluctant to engage in conflict within his own household or his own family, he would want to maintain peace when it came to matters of religion as well. In some ways, he was simply building on the relative religious tolerance that England had known under Elizabeth, relying on vague promises, equivocation, and outright deception to keep the various religious factions at bay.

James expanded his religious beliefs and practices during his lifetime, but Anna changed hers completely. As a member of the Danish royal family, Anna had been raised as a Lutheran, although it is difficult to determine the extent of her convictions or even how often she attended religious services during her early years. ${ }^{53}$ It is also uncertain when Anna converted to Catholicism exactly, but there is no doubt that she did, and that it was sometime after she moved to Scotland but before she moved to England. It is believed that Anna most likely converted due to the influence of her friend Henrietta Stuart, Countess of Huntley, who was the sister of the Duke of Lennox (the son of Esmé Stuart, a former favorite of James) and who would go on not only to become a prominent member of Anna's household, but also one of the queen's closest and most trusted friends. ${ }^{54}$ As with her childhood Lutheranism, it is uncertain exactly how devout Anna was as a Catholic, although there is certainly more information about her religion in

\footnotetext{
${ }^{52}$ W.B. Patterson, James VI and I and the Reunion of Christendom (Cambridge: Cambridge University Press, 1997), 3.

${ }^{53}$ Roy C. Strong, Henry, Prince of Wales, 25.

${ }^{54}$ David Mathew, James I (London: Eyre and Spottiswoode, 1967), 56.
} 
Scotland and England than there is for her time in Denmark. This lack of information is not indicative of Anna's lack of interest in her religion, but is more likely proof of her discretion. Anna's Catholicism would have made her a target in more ways than one, and it was certainly in her best interest to keep a low profile when it came to matters of faith. She would actively lobby for Catholic matches for her children, but then again, so would James in some cases. ${ }^{55}$

Anna's religious preferences would have placed her in opposition not just to her husband and the Scottish Kirk, but to a fair number of the English nobility as well. Her religion would also occasionally make her an unwilling and unknowing figurehead of pro-Catholic conspiracies, such as the now infamous Gunpowder Plot of 1605. In his book on the history of politics and ideas during the Stuart era, Kevin Sharpe references scholarship by D.M. Bergeron that suggests that religion was one of the key factors that drove the final wedge between James and Anna, along with the death of two of Anna's daughters, Mary and Sophia, shortly after their births, as well as James' preference for male company over that of his wife. ${ }^{56}$

Public personalities and religion, however, were certainly not the only contributing causes to the eventual split between James and Anna. They never divorced, of course. Even after the marital experiences of Henry VIII it was still not considered prudent for a king to divorce his queen unless he had suitable evidence (or he had been able to patch together suitable pseudo-evidence) that she had caused him some great

\footnotetext{
${ }^{55}$ British History Online, Calendar of State Papers Relating to English Affairs in the Archives of Venice, Volume 12 - 1610-1613, last date updated: 2011, $<$ http://www.british-history.ac.uk/source.aspx?pubid=1011>.

${ }^{56}$ Kevin Sharpe, Politics and Ideas in Early Stuart England (London; New York: Pinter Publishers, 1989), 281 .
} 
wrong. ${ }^{57}$ Besides, Anna had done her duties as a wife and mother. The marriage produced seven children: Henry, Elizabeth, Margaret, Charles, Robert, Mary, and Sophia, even though only Henry, Elizabeth, and Charles survived to adulthood, and Henry died at the age of nineteen after a long illness. ${ }^{58}$ Anna's religious beliefs conflicted with those of James, but given James' penchant for tolerance and his desire to avoid direct confrontation when it came to religion, it seems to have never become a significant problem. It is more likely that it was simply one more minor annoyance atop a heap of other problems that had been stewing between James and Anna since very early on in the marriage. There would also be the sheer lack of attention that James was willing to devote to his wife, attention that instead went to his court favorites, as well as the battle over the custody and raising of the royal children.

\section{Custody of the Royal Children}

In retrospect, it may seem unusual that Anna fought so vehemently for the right to raise her children in her own household. The practice of sending the royal children away from court to be raised by governors or other state guardians was hardly out of the ordinary in Early Modern Europe. Queen Elizabeth and her half siblings, Edward and Mary, spent most of their childhood away from the court, although this could have been because of the mercurial attitudes of Henry VIII towards his children and their relative legitimacy more than anything else. It is worth noting that even Edward, Henry's only male heir and the assumed successor to the English throne, did not spend much time at

\footnotetext{
${ }^{57}$ E.W. Ives, Anne Boleyn (Oxford; New York: Basil Blackwell Ltd., 1987), 113. Henry had to battle the church and the state in an attempt to invalidate his marriage to his first wife, Katherine of Aragon, so that he might freely marry Anne Boleyn. The long term repercussions of his actions shook England to its very core.

${ }^{58}$ Williams, Anne of Denmark, 47, 59-67, 105, and 112.
} 
the court of his father. Only Anne Boleyn, the mother of Elizabeth, made any serious attempt to maintain custody over her daughter, even going so far trying to breastfeed Elizabeth herself instead of employing a nursemaid. Of all of Henry's later wives, only Katherine Parr tried to re-incorporate the children back into court life and, by extension, their father's good graces. ${ }^{59}$ Given the nature of court life in Scotland (and later, in England as well), it was perhaps in the best interest of royal offspring to be raised away from the intrigue and politicking that were integral to the royal residences. For James, it would have also been a matter of safety for not only his children, but also himself. If the children were away from court, there was a lowered risk of courtiers trying to seize or manipulate them for their own gain. James was taking a page from his predecessor's book: by keeping the children away from court he reduced the possibility that one of the factions would attempt to overthrow him in favor of one of his children. That Anna herself could have assisted in one of these potential coups probably was not an impossibility in the king's mind.

In addition to these concerns about treason and assassination, there was the personal precedent of both James and Anna. Each of them had been raised away from the courts of their parents, although as has already been seen with James, his mother was not given a choice in the matter. James had been placed into the custody of the Estates of Scotland, who assigned the Earl of Mar to be the infant king's guardian, as was tradition. James was brought up by the Earl and his mother, the Countess of Mar, who later would

\footnotetext{
${ }^{59}$ Katherine Parr, Janel Mueller, ed., Katherine Parr: Complete Works and Correspondence (London; Chicago: University of Chicago Press, 2011), 82. In a letter from the Princess Elizabeth to her step-mother, it is apparent that Elizabeth both knew that Katherine Parr had the ear of the king, and that she could be trusted to put forward the best interests of the royal children.
} 
be a great adversary of Anna. ${ }^{60}$ Anna herself had been raised until the age of six by her maternal grandparents, Duke Ulrich III of Mecklenberg and his wife, Duchess Elizabeth, in the small German town of Güstrow. Anna's mother Sophia, however, remained an ever-present and influential parent to her children. It was after the birth of Christian, the assumed heir to the Danish throne, that the Danish council, the Risgraad, insisted that the children, or at least Christian, be removed from the potentially subversive German influences with which he was surrounded. From that point on, Sophia raised her children and actively worked to ensure their welfare herself. ${ }^{61}$

Perhaps it was because Anna had spent most of her formative years with her own mother that she would be so insistent on raising her own son. Anna enjoyed a good familial relationship with her mother and her siblings, as evidenced by their continued correspondence and the efforts her brother and uncles made to visit her in England, and she expected to have the opportunity to foster a similar sort of atmosphere when she had her own children, or at least be able to imitate the family structure to which she was accustomed. Anna had been trained to take on the mantle of a queen. Except for the example provided to her by her mother, it is unlikely that she had been instructed on what would be expected from her as a royal mother beyond producing at least one heir, and ideally a few male children to be kept in reserve. However, her mother's significant influence over the raising of her children probably contributed to Anna's surprise and outrage that she would not have similar autonomy in this matter.

Before any of this would come to pass, however, Anna had to produce a child to raise in the first place. As early as June 1593, James was hopeful that Anna was pregnant.

\footnotetext{
${ }^{60}$ Akrigg, Jacobean Pageant, 6.

${ }^{61}$ Williams, 2-4
} 
When it was announced in October 1593 that Anna was indeed carrying her first child, a general wave of joy swept through the kingdom that was shared by James himself. ${ }^{62}$ James knew that a legitimate, male heir would strengthen his case as a potential successor to the English throne with Elizabeth and her council. There is no record of how Anna responded to the rumors, or how she felt about her impending pregnancy. When it came to birthing royal children, the mother was only of marginal significance, providing she could produce a healthy child. Queens were replaceable, as was made abundantly evident by Henry VIII. That no one bothered to record Anna's thoughts or opinions during this time is not unreasonable for the time, since the pregnancy would have been a matter of state and, therefore, a public matter. Anna's pregnancy was not something that belonged to her, even at this stage.

Additionally, Anna was given no voice when it came to making the arrangements for the birth of her first child: James selected Stirling Castle, the place where he had lived as a child, for Anna's laying in and the birthing. Queen Elizabeth herself was named the godmother, although she would naturally send a proxy agent to stand in at the christening. Prince Frederick Henry, named for his two grandfathers, was born on 19 February 1594. The christening of the infant prince was delayed for several months due to complications revolving around Elizabeth's representative and godparent stand-in, the Earl of Cumberland. Eventually, the young Earl of Sussex was sent in his place, and Henry was finally baptized on 30 August 1594 in the first royal christening performed according to the Protestant rites in Scotland. ${ }^{63}$ For a brief time, Anna was able to maintain custody of her son. Since there is no record of Anna's thoughts regarding her

\footnotetext{
${ }^{62}$ King James VI \& I, Akrigg ed., Letters of King James VI \& I, 126-127.

${ }^{63}$ Strong, Henry, Prince of Wales, 9.
} 
unborn child, there is no way of determining whether she assumed she would be allowed to raise her child herself or not. Anna does seem to have been taken by surprise by what happened next.

In autumn 1594, James informed Anna that the Earl of Mar would be given custody of Prince Henry, as was traditional. James himself had been brought up by the father of the present Earl of Mar. It has been suggested that there may have been political reasons behind James' refusal to allow Anna to raise Henry herself. James had not had an ideal childhood, even by the standards of the time: as previously noted, he had been kidnapped and used by a rival political faction against his own mother, and as a result he feared that a similar plot using his newborn son would be employed against him. There was also the fear that that Anna herself would use Henry to claim more power from James, or act as a rallying point for rival nobility to overthrow James and put the infant Henry on the throne. ${ }^{64}$ This was not entirely an unfounded fear on James' part, given his early experience. Scotland had a bad track record when it came to political stability, and the situation was still not ideal when James reached his majority and took full control of his government in 1583 .

Scotland during the time of James' reign ${ }^{65}$ was rife with political fighting and intrigue. The wave of unrest with which James was dealing as king had begun during the reign of his mother Mary, Queen of Scots, from 1542 until she was forced to abdicate in favor of her son in 1567. After returning from France as a nineteen-year-old widow in 1560, Mary had been intent on claiming the throne in her own country after she had been

\footnotetext{
${ }^{64}$ Willson, King James VI and I, 117.

65 James' reign lasted from 1567 to 1625 , although, as noted above, James himself did not gain control of his own country until several years after he had been crowned, in 1583.
} 
denied the French throne. In a move that shocked and angered her cousin, Elizabeth, and the Scottish nobility, Mary wed her first cousin, Henry Stewart, Lord Darnley. She quickly grew bored with her new husband, however, and in his frustration Darnley conspired with the Protestant lords of Scotland to murder Mary's secretary and confidante, the Italian David Rizzio. This ultimately led to the murder of Darnley himself in April 1567 by Mary's next paramour, the Earl of Bothwell. ${ }^{66}$ These events left the country in turmoil, with the nobility divided amongst themselves not only along religious lines, but also in terms of personal loyalties and ideas about how Scotland ought to be ruled, and by whom. It was under these conditions that James was used and manipulated by the Scottish Kirk to depose his mother and further the agendas of a single political party. Later, as king of Scotland, James had an eye for the English throne, and it would not have reflected well on him if he had not been able to control his own nobility, or if they had been able to mount any sort of resistance against him.

Consequently, by sending his son to live with the house of Mar, James was simply trying to maintain his throne, his kingdom, and his future. He knew and trusted the Earl, who had been an early playmate and had grown up alongside James. He also trusted the Countess, who had been his only mother figure growing up and who had treated him like her own child. It is very unlikely that he was removing Henry from court strictly to antagonize Anna. James was not an aggressive man, and he would go out of his way to avoid conflict. The choice of the Earl of Mar as guardian was probably motivated more by convention, personal experience, and trust than by any desire to offend or to irritate his wife.

\footnotetext{
${ }^{66}$ Ibid., 15-18.
} 
The end result, however, was the same. Given the chilly reception she had received from the Earl and his mother, Anna had little reason to like Mar and, although the Earl was trusted completely by James, she had every reason to find him to be untrustworthy. He had, after all, been party to the Ruthven raid (which will be discussed in a later chapter) that had presented a real threat to King James when he was a child, and Anna did not want to see her son used in the same way. Consequently, her actions do not present her as being a petulant woman who was being disagreeable because she did not get her way. Rather, Anna was keenly aware of the political situation around her, and the possible repercussions of allowing the Earl of Mar to maintain custody of Henry.

It is obvious that Anna desperately wanted to keep her son with her, and when she was not allowed to do so, the fallout marked the end of any sort of amicable friendship with her husband. In the end, James won the day, and Henry was sent to live at Castle Stirling. James would soon learn, however, that Anna would not give up Henry so easily. In the summer of 1595, while James was away on one of his hunting trips, Anna once again made an attempt to regain custody of her son, assisted by the half-hearted Chancellor John Maitland, as well as by Sir Robert Ker of Cressford and Lord Home. James, however, found out about the plan before it was ever carried out, and returned to Falkland to see that it never came to fruition. While he severely chastised Anna for her actions, he also consented to take her to Stirling Castle to see Henry for a short time. Later, he would write a letter to the Earl of Mar to ensure that he would not hand Henry over to Anna or her cohort:

My Lord of Mar: Because in the surety of my son consisteth my surety and I have concredited unto you the charge of his keeping upon the trust I have of your honesty, this I command you out of my own mouth, being in 
company of those I like, otherwise for any charge or necessity that can come from me, you shall not deliver him. And in case God call me at any time see that neither for the queen nor Estates, their pleasure, you deliver him till he be eighteen years of age, and that he command you himself. ${ }^{67}$

For the moment, at least, it seemed as though Anna had lost. The battle for custody over Henry, however, was far from over. It would emerge again with renewed vigor nine years later in 1603, when James finally heard the news he had been anxiously awaiting for years: Queen Elizabeth I was dead, and he was now the king of England and Ireland, as well as Scotland.

James did not waste any time leaving Scotland for his new kingdom, and began his progress south on 5 April 1603. James took his time arriving however, as his abhorrence for funerals gave him reason to avoid Elizabeth's, which was held on April 29. At this time, he was not accompanied by Anna or his children, partially because Anna was in the middle of her sixth pregnancy and partially because none of the English ladiesin-waiting that James had selected for Anna would be available until after the previous queen's funeral. Anna was scheduled to depart about three weeks later, and follow much the same route that her husband had travelled. What James had not counted on was Anna's renewed insistence that she be granted custody of Prince Henry, and that she should be allowed to bring her son Henry along with her to England. ${ }^{68}$

James, who had barely had time to settle in to his new role in England, was less than pleased at his wife's latest attempts to retrieve their son. He wrote her a letter that, although it was addressed to "My heart," was filled with admonitions about her attitude toward the Earl, whom she had apparently accused in a previous letter of slandering her

\footnotetext{
${ }^{67}$ J.O. Halliwell, ed., Letters of the Kings of England, Vol. II (London: H. Colburn, 1846), 91-92.
}

${ }^{68}$ Akrigg, Jacobean Pageant, 18-22. 
name and claiming that she was a papist or a sympathizer of the Spanish, as well as admonitions in response to her continued demands regarding Prince Henry. James seemed to take Anna's actions as a personal affront as a man and as a king, rather than thinking of her motives as arising from a mother wanting to raise her son:

I beseech you excuse my rude plainness in this, for the casting up of your birth [as the daughter of a king] is a needless argument to me. God is my witness I ever preferred you to all my bairns [children], much more than to any subject. But if ye will ever give place to report of every flattering sycophant that will persuade you that when I account well of an honest servant for his true service to me, it is to compare or prefer him to you, then will neither ye or I be ever at rest. ${ }^{69}$

Anna refused to be placated, however, and she used James' absence and distraction as an opportunity to attempt once again to seize Henry from the house of Mar. The Earl of Mar had travelled to England with James, but his mother Annabelle, the Countess of Mar, was still in residence at Stirling Castle, where she had custody of Prince Henry. Anna arrived at the castle with a contingent of sympathetic nobles, all of whom were, not surprisingly, refused admission into the castle. The Countess stated that she would not hand over Henry unless she had permission directly from James. ${ }^{70}$ In fairness to the Countess, even if she had been friendly towards Anna it would have been foolish for her to disobey a direct written missive from the king stating that the prince was not to be delivered to Anna or any of her allies. Both the countess and her son were largely reliant on James for their position and prestige in the Scottish court, and now in the English one as well. To suggest that she was withholding Henry out of sheer vindictiveness towards Anna ignores several other aspects of the political situation:

\footnotetext{
${ }^{69}$ King James VI \& I, Akrigg, ed., Letters of King James VI \& I, 214-215.

${ }^{70} \mathrm{~T}$. Birch, The Life of Prince Henry of Wales (London: Printed for A. Millar in the Strand, 1760), 29.
} 
whether of not the Countess like Anna, there were other more practical factors at work as well.

Anna did not take this refusal well. She worked herself up so much that she developed a high fever, and she miscarried her sixth pregnancy. Something clearly had to be done, and Lord Fyvie, the President of the Scottish Council, intervened with King James and counseled him to use moderation when dealing with Anna:

$[\mathrm{P}]$ hysic and medicine requireth greater place with her Majesty at present than lectures on economics or politics... Her Majesty's passions could not be so well mitigated or moderated as by seconding and obeying her directions, which always is subject to your sacred Majesty's anxieties and resolves as answers. ${ }^{71}$

James finally decided that enough was enough. He realized that he had to give something to Anna or risk estranging his wife and remaining in England as a single king, which would do nothing to endear him to the English people. He also did not wish to see Anna go through another miscarriage, since James was always concerned with the line of succession. He already had Prince Henry, but the next male child after that was Prince Charles, who at that time was still a weak and sickly child. As a result, James sent the Earl of Mar to retrieve Anna and Henry from Scotland. This action was in itself hardly a gesture of goodwill on James' part: while he was consenting to bring Henry to England with Anna, he knew that Anna detested and mistrusted Mar. ${ }^{72}$

Instead of accepting this arrangement and travelling to England with her son in the company of the Earl of Mar, Anna decided to risk angering her husband and to make

\footnotetext{
${ }^{71}$ British History Online, Calendar of State Papers Venetian, 1610-1613, last date updated: 2011, $<$ http://www.british-history.ac.uk/source.aspx?pubid=1011>.

${ }^{72}$ British History Online, Calendar of State Papers Relating to English Affairs in the Archives of Venice, Volume 12 - 1610-1613, last date updated: 2011, < http://www.british-history.ac.uk/source.aspx?pubid=1011>.
} 
another attempt to seize Henry from his guardians. It was a gamble, but it was a calculated one. She had already established that James was keen on keeping the peace within his own household, since he had never really reprimanded her for her previous attempts to retrieve her son. With the added pressure of his new responsibilities in England, her husband was unlikely to put up as much of a fight in order to maintain the services of a favored Scottish courtier (the Earl of Mar) now that he also had the English court to run. James did have to retain control over his Scottish nobles, but taking the guardianship position away from Mar was not going to have significant consequences in the broader scheme of Scottish politics. Ultimately, Mar would not be demoted in any way, following Anna's successful wresting of Henry from his control, and in fact he would remain a favorite of King James even after the latter had taken up residence in England. If anyone was going to suffer a blow to their image or prestige by allowing Anna to assume custodianship of Henry and to bring him with her to England, it would be James, since he was bending to his wife's demands. Mar would simply be a casualty of his master's weakness.

James finally relented to Anna's demands for her son. On 13 May 1603 he sent a letter to the Earl of Mar from Greenwich:

It is our will that for her [Anna's] better satisfaction ye delyver the same [Prince Henry] to any of the Counsell to be given to her and disposed upon as she pleaseth, in case she continew in that wilfulness that she will not heare your credite nor receave the same from your owen handes. ${ }^{73}$

Mar was then ordered to hand Prince Henry over to the Scottish Council, who would hand the boy over to the Duke of Lennox, who would then deliver him to Anna. Anna

\footnotetext{
${ }^{73}$ Historic Manuscript Commission, Report on the Manuscripts of the Earl of Mar and Kellie (London: Ben Johnson and Co., 1904), 51.
} 
herself would bring the boy to England via Edinburgh, escorted by Lennox rather than by the Earl of Mar, as a further concession from James. ${ }^{74}$ To cement Anna's victory further, on 28 June 1603 the Earl of Mar was officially released from his guardianship by James:

The King has now released the Earl of Mar from his charge as guardian to the young prince, in whose safe keeping he has remained since he was an infant, very handsomely acknowledging the care taken by my Lord in that service. $^{75}$

Anna had, at last, won. The question remains, however, as to why the battle was fought in the first place. Why was Anna so keen on retaining custody of Henry, when, as will be seen, she seemed willing enough to allow her other two surviving children to be raised by other families? In order to answer this question, it is necessary to look at the circumstances in which Princess Elizabeth and Prince Charles were placed as compared to those of Henry.

\section{Elizabeth and Charles}

Elizabeth was born on 19 August 1596, and was named after her godmother, Queen Elizabeth I. The total lack of pomp and ceremony surrounding the birth of this royal daughter would foreshadow the rest of her life (with the exception of her wedding day). There was simply no money available at the Scottish court to provide lavish birthing or christening ceremonies, and since Elizabeth was a daughter (and a second child at that), there was little reason to make a large presentation of her. Furthermore, Elizabeth's father was highly distracted, as he was involved in a conflict with the Presbyterian ministers of Scotland, who were angry with James over his treatment of the Reverend David Black, their figurehead and champion, and who were growing

\footnotetext{
${ }^{74}$ Ibid.

${ }^{75}$ G.B Harrison, ed., A Jacobean Journal: Being a Record of Those Things Most Talked of During the Years 1603-1606 (London: George Routledge and Sons, Ltd., 1946), 41.
} 
increasingly loud regarding the alleged conversion of Anna to Catholicism. ${ }^{76}$ Elizabeth was finally christened in a simply ceremony in the Chapel Royal at Holyrood House on 28 November, three months after her birth. In a move that cannot have come as a surprise to Anna at this point, she was not allowed to keep her newborn daughter. Instead, Elizabeth was entrusted to Lord and Lady Livingston. This choice of guardians did not sit well with the Scottish Kirk: Andrew, Lord Livingston, was the nephew of one of the four Maries that had served Mary, Queen of Scots, and his wife was the daughter of a known Catholic, the eighth Earl of Errol. Despite the perceived threat of Catholic influence, Lady Livingston was a capable and loving guardian to the young princess, who became quite attached to her, and later Elizabeth's younger sister Margaret during the latter's brief life. (Margaret died at the age of two. $)^{77}$

It is possible that the Catholicism of Lord and Lady Livingston encouraged Anna to be less hostile towards the idea of their guardianship over Elizabeth and Margaret. There is no evidence that Anna ever had any quarrels with them as she had with the Earl of Mar and his mother, nor is there any record of her making any concerted effort to regain custody of her daughters from them. Anna, who focused a great deal of energy into grooming her son Henry to be king, would not have seen the same potential in Elizabeth. As a male child, Henry already had an entrée into the Jacobean court and a claim to its power and influence; power and influence from which Anna herself could benefit if Henry felt any sort of filial bond to her. Elizabeth would eventually have potential as a marriageable young woman, and at that point her mother would take an

\footnotetext{
${ }^{76}$ Robert Rait, Five Stuart Princesses (London: A Constable \& Co., Ltd., 1902), 51.

${ }^{77}$ Williams, Anne of Denmark, 60.
} 
active interest in her, but during her daughter's childhood Anna thought that it was better to focus on preparing Henry for kingship rather than on Elizabeth.

Anna's youngest son, Charles, presented a different challenge. Anna's last successful pregnancy produced a child that was sickly and weak from the day he was born, 19 November 1600 . The fact that he survived infancy surprised doctors, who had warned Anna that he was unlikely to survive his first few weeks, let alone make it to his first birthday. When Charles defied the medical odds and lived, he was quickly baptized, with the Huguenot Prince de Rohan and his brother, the later Duke of Soubise acting as godfathers and the Countess of Mar and the Countess of Huntley acting as godmothers. The baby Charles remained weak and quite ill, but he did not die. He would, in fact, go on to live a relatively normal life as a teen and young adult. It is also true, however, that the young prince was said to have not learned to speak properly or walk properly until he was several years old. The fact that he did eventually learn to walk and talk successfully, however, was seen as remarkable by doctors at the time. ${ }^{78}$ Again, to the consternation of the Scottish Kirk, a royal infant had been placed in the care of suspected Catholics. ${ }^{79}$ This time the selected guardians were Lord Fyvie, the Constable of the Palace, and his wife, who proved to be loving and competent surrogate parents to the disabled Charles, patiently helping him learn to walk and talk. ${ }^{80}$

When Anna first left Scotland for England in 1603, Charles did not accompany her. This was not because of any overt lack of motherly love or concern, but rather

\footnotetext{
${ }^{78}$ Pauline Gregg, King Charles I (Berkeley, CA; Los Angeles: University of California Press, 1984), 4, 12.

${ }^{79}$ Willson, King James VI and I, 122.

${ }^{80}$ Williams, Anne of Denmark, 66.
} 
because Charles' doctors had determined that he was too ill to make the journey. ${ }^{81}$ Indeed, Anna continued to correspond with Lord Fyvie and with her son's doctors and, on 3 July 1604, one of the doctors attending Charles wrote to Anna to inform her that her son was doing much better and might soon be able to join her in England:

Our noble prince, your Majesty's dear son, daily growing from one perfection of health to another. His Highness now walketh many times in a day all the length of the great chamber at Dunfermline like a gallant soldier all alone. He often talketh of going to London and desireth to see his gracious mother. ${ }^{82}$

Having received this missive, Anna immediately sent yet another doctor and an apothecary to Scotland to determine whether or not Charles might finally join her in England. The doctors decided that, although Charles was still weak, it would be safe for him to make the journey in slow stages. In August, and reportedly to Anna's great joy, Charles arrived in England. He was immediately put in the care of Sir Robert and Lady Carey, who exhibited the same love and patience with Charles that his previous guardians had shown him. In fact, Lady Carey became an outspoken opponent of James' more medieval approach towards curing Charles:

The Duke was of past four years when he was first delivered to my wife [Lady Carey], he was not able to go nor scant stand alone, he was so weak in his joints... Many a battle my wife had with the King but she prevailed. The King was desirous that the string under his [Charles'] tongue should be cut, for he so long beginning to speak as he thought he would never have spoke. Then he would have him put in iron boots to strengthen his sinews and joints. ${ }^{83}$

The king had also apparently suggested that Charles's tongue be cut to facilitate his speech, perhaps haunted by his own speech troubles: "The Duke [Charles]... is so slow in

\footnotetext{
${ }^{81}$ Akrigg, Jacobean Pageant, 21.

${ }^{82}$ British History Online, Calendar of the Cecil Papers in Hatfield House, Volume 16: 1604, last date updated: $2011,<$ http://www.british-history.ac.uk/report.aspx?compid=112201>.

${ }^{83}$ Robert Carey, Memoirs, 141.
} 
beginning to speak that the King was desirous that the string of his tongue should be cut... but the Lady Carey will not allow it." ${ }^{84}$ Obviously, these suggested methods of treatment did not go over well with Anna, and she was a strong supporter of Lady Carey's campaigns against the king. She herself believed that a more gentle and patient approach with Charles would be the most effective, and in the long run both women were vindicated when Charles became a healthy and active child who was loved and protected by his elder siblings, whom he in turn loved and greatly admired. ${ }^{85}$

Despite the care and concern she showed to her youngest child, Anna was never as adamant about raising Charles herself as she had been about Henry. While she was certainly involved with Charles' early development and upbringing, she also did not have the same resistance to allowing first Lord and Lady Fyvie, and later Sir Robert and Lady Carey, to take custody of her youngest son. As with Elizabeth, the perceived Catholic leanings of Lord and Lady Fyvie would have endeared them to Anna more than had the Earl and Countess of Mar. There was also no previous enmity between Anna and Charles' guardians, which seemed to have been at least part of the problem with the ongoing struggle over Henry. Also, although a male child and heir, Charles was a second son. While still potentially useful (and while still providing a spare son in case Henry met an untimely end without producing any male heirs of his own), Charles was overshadowed, at least from a political standpoint, by his elder brother. As will be seen later in this chapter, there is little doubt that Anna cared greatly for Charles, but she was also a highly pragmatic woman. Anna yielded in raising Charles for the same reason she

\footnotetext{
${ }^{84}$ Harrison, A Jacobean Journal, 162.

85 Ibid.
} 
did so with Elizabeth and Margaret: she found it more practical to invest her time and energies cultivating Henry.

\section{Henry, Prince of Wales}

As has already been seen, Henry's early childhood was spent largely away from his parents. Consequently, it is difficult to trace any influence that Anna had on him during these early years. After the royal family's move to England, however, it became clear that Henry loved and admired his mother, and that he emulated her in several areas of his own life. In an "anonymous" source (W.H., almost certainly William Haydon, the most senior groom of Prince Henry's English bedchamber), we find the following description of the young prince:

He was tall and of an high stature, his body strong and well proportioned, his shoulders were broad, his eyes quicke and pleasant, his forehead broad, his nose bigg, his chinne broad and clouen, his hair inclining to bleeke... his whole face and visage comely and beautifull, looking for the most part with a sweete, smyling, and amiable countenance...resembling much in shape of his body, and diuers actions the King of Dennemark his [U]ncle. ${ }^{86}$

Henry's resemblance to Anna and her family was not limited to his physical appearance. It was from Anna that Henry inherited a love of the arts. During the Tudor period, most of the art that was collected by the royal family had been acquired by or for Henry VIII. Edward VI and Mary I had little time to add much to the royal collection, and Elizabeth I seemed to have had little interest in it. James himself did not seem to have had much interest in painting or sculpture, and he hated sitting for his own royal portraits. It was under Anna that the accumulation of art and the patronage of artists once again began to rise. Her residences at Somerset House (London), Greenwich, and

\footnotetext{
${ }^{86}$ W.H., The True Picture and Relation of Prince Henry (Leyden: William Christian, 1634), 31; as quoted in Strong, Henry, Prince of Wales, 11-12.
} 
Oatlands were all home to large collections of art. What is unique about Anna's collections is that, for the first time in England, they included not only portraits of ancestors, family, and friends, but also a significant number of still-lifes, paintings of mythological subjects, devotional pictures, and landscapes. She was a patron of the socalled "new wave" portraitists, Isaac Oliver and Marcus Gheeraerts, and she was the most notable patron of Inigo Jones and his innovative stage designs and machinations. Henry would not only continue the tradition of patronage and commission, but would build upon it and become an even more avid collector of art, both new and antique, than even his mother. $^{87}$

As evidenced by his large art collection and his patronage of the same artists, architects, and writers as Anna, it is clear that Henry was strongly influenced by his mother when it came to his passion for art. While this may seem like a relatively unimportant aspect of Henry's short life, it still serves as an indication that Anna influenced her son regarding his appreciation of art and, consequently, she likely influenced him in other, perhaps more profound, areas of his life. Anna was also being forced to make up for lost time: since she had had little to no contact with her son for the first nine years of his life, it was crucial that she try and merge herself and her interests with her son's if she was to succeed at remaining relevant at court. If Anna really did see Henry as her opportunity to exercise more power and influence at court, then it is not unreasonable that she would have looked for every possible avenue that could be used to strengthen the bond between mother and son.

\footnotetext{
${ }^{87}$ Strong, Henry, Prince of Wales, 186-187.
} 
As a result of Anna's influence and encouragement, Henry also found a creative outlet in another of her pet projects: the court masque. In June 1610, Henry was officially made the Prince of Wales, and Anna commissioned the masque Tethys Festival to mark the occasion. Anna herself portrayed Tethys, the daughter of Uranus. The Princess Elizabeth was also present, representing the nymph of the river Thames, as was Charles, who portrayed Zephyrus, and who presented his father and elder brother with gifts during the production. On New Year's Day of 1611, Henry himself presented his first masque: Oberon: The Fairy Prince. His mother produced a companion play to Oberon, Love Freed From Ignorance and Folly, on 3 February of that same year. This would be the last masque in which Anna would have a direct role; after Henry's death her interests moved away from the world of masquing and to other interests. ${ }^{88}$

During his lifetime, however, Henry and his mother enjoyed a good bond. Despite the fact the Henry had spent the first nine years of his life in the care of someone other than his mother, or maybe because of this, he and Anna had a close and loving relationship. It could be debated whether Henry or Charles was more loved by Anna (Elizabeth never seems to come up in that particular discussion), but it is impossible to come to a clear conclusion. Even if a valid conclusion could be reached, the argument is largely pointless. Anna clearly displayed affection towards all of her children, although that affection manifested itself in very different ways. Henry, as the oldest, had the advantage of Anna's additional attention since she was grooming him as the heir to the throne.

\footnotetext{
${ }^{88}$ McManus, Women on the Renaissance Stage, 3; Ben Jonson, Clark Holloway, ed., Oberon, the Fairy Prince: A Masque of Prince Henry's (London: William Stansby, 1616), last date updated: 2003, $<$ http://hollowaypages.com/jonson1692oberon.htm>.
} 
Of course for Henry, this extra attention also brought with it the added responsibility of acting as an intermediary between his mother and father after he had established his own court. Henry was inclined to side with his mother, and it appears that he was much closer to her than he ever was to his father. ${ }^{89}$ James and Henry could not have been less alike: James was loud, coarse, and occasionally bawdy (at least from the English perspective). Henry, on the other hand, was an eloquent and charming young man who learned manners and etiquette from his mother, as well as the Countess of Mar. He made his court a center of sober living and respectable behavior. A particularly humorous anecdote illustrates this difference. While James was well-known for his profanity, Henry would keep boxes about his lodgings into which those who swore would be required to pay a fine, with all the proceeds being donated to the poor. It was, in fact, an early modern English swear jar. If Henry had one vice that his father did not, it was a weakness for women. Beyond that, he presented an ideal picture of propriety, even attending private devotions three times a day and requiring that members of his household also attend prayers every day. ${ }^{90}$

Since Anna herself was well-known for her flawless manners and impeccably noble behavior, she was certainly partly, if not wholly, responsible for influencing Henry's upstanding behavior. On the other hand, it is important to remember that Henry lived with the Earl and Countess of Mar for the first nine years of his life. While little has been written about this time in the prince's life, it has to be assumed that one or both of his guardians during his early childhood would have had some influence on his demeanor as well. While the Scottish court (as exemplified by the behavior of James himself) was

\footnotetext{
${ }^{89}$ Strong, Henry, Prince of Wales, 16-17.

${ }^{90}$ Akrigg, Jacobean Pageant, 131.
} 
not exactly considered the epitome of decorum by their neighbors in the south, this should not be taken to mean that all Scottish courtiers were boorish oafs. In particular the Countess of Mar, with her high-minded ideas about who would be good enough to marry James and rule as queen of Scotland, would have been an early influence on Henry and his manners.

There were two areas of his life in which Henry differed significantly from his mother. First, he had an excellent head for money management and the running of his own household. Anna had either very little understanding of or very little concern for the value of money and was often in debt. Her husband was no better. Henry's accounts, on the other hand, actually turned a profit under his careful guidance. ${ }^{91}$ The other aspect of Henry's life that stood in stark contrast to Anna's was his religion: in contrast to Anna's Catholicism, Henry was fiercely Protestant. Despite this, religion does not seem to have been a point of contention between mother and son. ${ }^{92}$ Anna was very discreet and quiet about her religious leanings, and as such it did not affect the mother-son bond between Henry and Anna. Also, Henry would have understood that Anna was in no position to affect anybody else's religion, and so did not pose any real threat to his Protestant church.

The issue of religious difference between mother and son would be thrown into sharp relief during one critical junction of Henry's life, however: the negotiations for his eventual marriage. Surprisingly, this seems to have been the one topic on which Henry deferred to his father. He followed protocol and procedure to the letter, and did not offer

\footnotetext{
${ }^{91}$ Ibid., 132.

${ }^{92}$ Strong, Henry, Prince of Wales, 25.
} 
his own thoughts on any of the prospective brides unless his father asked his opinion. ${ }^{93}$ Anna, desired a Catholic match for her son, possible with Spain or Savoy. James had an equal desire to see Henry married to a Catholic power. According to the Venetian ambassador at court, James' logic was that, since he had married his daughter off to a Protestant prince, a Catholic marriage for Henry would retain some semblance of a balance of power between religions in his foreign policy. ${ }^{94}$

The first proposed match was with one of the daughters of the Duke of Savoy. Another possible match was with the Spanish royal family, which offered the infanta as a possible wife. This particular match, however, fell through when the English discovered that not only was the infanta only six years old, but that Henry himself would be expected to move to Spain and convert to Catholicism. Next, a marriage to one of the daughters of the noble Medici family of Florence was put forth, but this also came to naught. Meanwhile another Medici, Marie de' Medici of France, also offered her nine year old daughter Christine as a potential match. Finally, it seemed as though James would backtrack to the first proposed marriage and accept a match with Savoy, with a wedding to be celebrated sometime in October $1612 .^{95}$

For Anna, Henry's successful diplomatic marriage would have been, in some way, a satisfying result of her nurturing and guidance of the young prince. For Henry, the entire process was quite trying: he was, of course, a staunch Protestant, and to know that both of his parents were seeking a Catholic marriage cannot have been welcome news. It

\footnotetext{
${ }^{93}$ Manuscripts of the British Museum Library, Harleian 6986, f. 180v ; as quoted in Akrigg, Jacobean Pageant, 133.

${ }^{94}$ British History Online, Calendar of State Papers Relating to English Affairs in the Archives of Venice, Volume 12 - 1610-1613, last date updated: 2011, $<$ http://www.british-history.ac.uk/source.aspx?pubid=1011>.

${ }^{95}$ Strong, Henry, Prince of Wales, 80-83.
} 
is to his credit that he accepted the will of his parents rather than argue, which would involve behavior unbefitting of a royal child. Henry understood, just as his mother did, that for the sons and daughters of kings, marriage would never be a matter of choice or personal preference. As a future king, he also understood that the marriage would be a business contract, nothing more. He witnessed firsthand the separate lives that his parents lived, and (given the precedence set by previous English kings, including Henry VIII), he would have been aware of the fact that royal mistresses were easy to come by and were generally overlooked.

No marriage came to pass, however. In the spring of 1612, Henry fell ill, though he continued to push his mind and body to the limit by hunting and playing tennis. However, by late autumn, Henry's condition had deteriorated to the point that he finally had to take to his bed. On 6 November 1612, Henry died of what is believed to have been typhoid fever. Sir Charles Cornwallis, who was there with the prince during his final hours, recorded the following:

His Highnesse, quietly, gently, and patiently, halfe a quarter, or thereabouts, before eight a clocke at night, yeelded up his Spirit unto his Immortall Maker. ${ }^{96}$

Thus ended the life of Henry, Prince of Wales. Anna was, understandably, distressed, both for the death of her son as well as for the death of what he represented. She was not alone in her mourning: to the English people, Henry had represented a great hope for the future. In many ways, he had embodied the Elizabethan traditions of chivalry, naval prowess, and anti-Spanish sentiment that had marked the so-called Golden Age of

\footnotetext{
${ }^{96}$ Charles Cornwallis, The Short Life and Much Lamented Death of That Most Magnanimous Prince, Henry, Prince of Wales (London: Printed for [J]ohn Benson, 1641), sigs. E6 ${ }^{\mathrm{v}}$ and E7 ${ }^{\mathrm{r}}$; as quoted in Akrigg, Jacobean Pageant, 133-135.
} 
Elizabeth. When he died, this hope died with him, and the people of England were forced to look to Charles, who was physically less imposing than his older brother and more inclined to intellectual pursuits rather than those involved with hunting or warfare. ${ }^{97}$ In short, Charles represented a future that looked very similar to the present situation under James. Following Henry's death, Anna would focus her attentions on her youngest son, who was now the heir to the throne. But she did not totally ignore her daughter, Elizabeth, especially when it was time to arrange an appropriate marriage.

\section{Princess Elizabeth Stuart, First Daughter of Scotland}

For all the attention that Anna focused on Henry, she seems to have paid little to no attention to her only surviving daughter. Elizabeth was certainly never wanting for anything, but her parents seem to have had little interest in her. As a result of being all but ignored during her life, there has been less written about the Princess Elizabeth than her brothers. She is described as having been graceful, athletic, playful, spontaneous, high-spirited, generous, affectionate, and charming, with a zest for life and a happiness that seemed to remain untainted even after she came to court. She was perhaps not the most aesthetically pleasing woman at court: while she inherited her mother's golden hair and tall figure, her nose and eyes were large like her father's. The French ambassador to James' court, Monsieur de La Boderie, seemed to find her a charming child: “"full of virtue and merit, handsome, engaging, very well-read, able to speak French exceedingly well, much better than her brother." ${ }^{98}$ Consequently, although she may not have been a great beauty, Elizabeth exhibited many of the characteristics that would be desirable in a

\footnotetext{
${ }^{97}$ Malcolm R. Smuts, Court Culture and the Origins of a Royalist Tradition in Early Stuart England (Philadelphia: University of Pennsylvania Press, 1987), 27-29.

${ }^{98}$ Willson, King James VI and I, 281-282.
} 
potential bride. It is even possible that the French ambassador made this specific observation with the understanding that it might be relevant during future marriage negotiations.

Beyond this and a few other brief mentions by foreign dignitaries, however, Princess Elizabeth was largely ignored by the larger world of court life until negotiations for her marriage began in earnest. This was perhaps the best possible situation for a royal child: Elizabeth was raised away from the intrigues and potential dangers of the royal court and allowed to live a relatively normal childhood. Although at the age of fourteen (as noted earlier), the princess did make an appearance in her mother's masque Tethys Festival, in celebration of Henry's investiture as Prince of Wales, such an appearance was exceptional. $^{99}$

Williams has suggested that Anna was less devoted to Elizabeth not because of any lack of love or because Elizabeth was a less politically valuable female child, but rather because Anna recognized in her daughter many of her own character traits: a lively and happy nature, stubbornness, and courage in times of trouble. ${ }^{100}$ If this is true, then Anna simply believed that Elizabeth needed her less than either Henry, who would be expected to rule one day, or Charles, given his physical challenges. There was, however, one area of Elizabeth's life in which Anna took a great deal of interest: the finding of a husband. Anna's intense interest in the marriage negotiation process indicates that she understood how much a favorable match could further not only the fortunes of her daughter and those of England, but also her own interests. For example, a match with a

\footnotetext{
${ }^{99}$ Samuel Daniel, Tethys Festival: or, The Queen's Wake (London: Printed for John Budge, 1610), 310.

${ }^{100}$ Williams, Anne of Denmark, 153.
} 
Catholic power would allow Anna herself more flexibility when it came to the practice of her religion.

By this time in history (the early seventeenth century), England was no longer a backwater kingdom struggling to be heard, but was a powerful European entity with some degree of influence and bargaining power, and Princess Elizabeth had many potential suitors. Anna herself preferred a Roman Catholic match for her daughter, and had entrusted Sir John Harrington, Elizabeth's guardian in England, to carry out the negotiations with the Duke of Savoy, Charles Emmanuel. Unfortunately, these negotiations fell through, and Harrington expressed his dismay and concern regarding his failure in a letter he wrote to Lady Arbella Stuart, whom he hoped would be able to persuade the Queen of his continued good intentions:

I know soch affayrs are comonly wayed by the successe, and those that fayl that ys imputed allways to the execucion rather than the direccion...Only I desyre that my soveraygn King and Queen may conceave, as the truthe ys, that my endeavors heerin have no other prospect nor retrospect, but my Loyall affection and dewty to them and theyr most deer Children. ${ }^{101}$

This was a more serious setback for Anna personally than it was for the marriage negotiations as a whole, and would have been a sort of triumph for James and Henry, neither of whom was particularly eager to see Elizabeth wed a Catholic husband. There was, after all, quite a list of eligible Protestant princes with whom to contract a match. The first in line was Gustavus Adolphus, the young king of Sweden. Given the bloody and violent history between Sweden and Anna's homeland of Denmark, it comes as no surprise that Anna swiftly and decidedly opposed the marriage. More surprising was the fact that Anna also opposed a match between her daughter Elizabeth and the

\footnotetext{
${ }^{101}$ Sir John Harrington, Sara Jayne Steen, ed., The Letters of Lady Arbella Stuart, 289.
} 
eldest son of her sister Elizabeth, Duke Frederick Ulric of Brunswick. Anna felt that the blood connection was too close for comfort (Elizabeth and Frederick Ulric were first cousins), and she was concerned that the boy would have inherited the less admirable traits of his father, Duke Henry Julius, whom Anna knew had been a poor husband to her sister. Next was the forty-six year old Prince Maurice of Nassau, who was roundly rejected by not only Anna, but by James and Elizabeth as well. Even Prince Maurice seemed uninterested in actually pursuing the marriage. The next two made no further progress than their predecessors: Otto, the son of the Landsgrave of Hesse, and Prince Christian of Anhalt were both rejected as potential husbands. ${ }^{102}$

Then, in 1612, out of Heidleberg came news of the young Elector Palatine, Count Frederick V (who also happened to be the nephew of Prince Maurice of Nassau). When Frederick arrived in England, James took to him instantly. He was handsome, a skilled horseman, and he made a great deal of effort to be studiously polite and agreeable to his potential in-laws. In fact, he possessed many of the traits that James looked for in his personal favorites. Despite all of this, Anna was not at all impressed with Frederick. She took to needling her daughter by referring to her as "Goodwife Palsgrave" at court, to which Elizabeth reportedly replied that she "would rather be the Palsgrave's Wife, than the greatest papist Queene in Christendom."

Why was Anna so vehemently opposed to the marriage between her daughter and Frederick? She seems to have had serious questions about the Count's character, which will be more thoroughly explored in a later chapter, but there was probably more to the

\footnotetext{
${ }^{102}$ Williams, Anne of Denmark, 153-154.

${ }^{103}$ Roger Coke, A Detection of the Court and State of England During the Four Last Reigns and the InterRegnum (London: Printed for Andr. Bell, 1697), 64.
} 
situation than concern for her daughter or disapproval regarding Frederick's relatively low status in comparison to Anna or Elizabeth. A union with one of the Germanic states was a risky proposition: the region was marked by political instability, and Anna, who had an understanding of English court politics, realized that to marry her daughter to Frederick would put England at risk of being involved in future Germanic wars.

Despite her misgivings, Anna eventually conceded when it came to the matter of her daughter's marriage. Elizabeth's wedding, however, was marred by Prince Henry's untimely death. Henry's own alleged last words before he fell completely into a state of delirium were: "Where is my dear sister?"104 Following Henry's death, the court entered a period of mourning, and Elizabeth's wedding was postponed. She finally wed Frederick on Valentine's Day in 1613, and despite being in dire financial straits, James insisted on providing a lavish ceremony for his only daughter. Elizabeth and Frederick were dressed in silver, and Elizabeth wore her hair down, with strings of pearls woven through it, and a coronet set with precious stones upon her head. James himself wore jewels that were valued around $£ 600,000$. Anna dressed in a white satin gown and wore jewels valued at $£ 400,000 .{ }^{105}$ After the wedding, Elizabeth left for the Palatinate, and Anna never saw her daughter again, which was of course a common occurrence at the time.

\section{Prince Charles, Duke of York}

There is some debate as to whether Henry or Charles was Anna's favorite child. It has been suggested that it was because of Charles' physical disabilities and challenges that he was Anna's favorite child: he showed a significant amount of courage and

\footnotetext{
${ }^{104}$ British History Online, Calendar of State Papers Domestic, November 1612, last date updated: 2011, $<$ http://www.british-history.ac.uk/report.aspx?compid=51467>.

${ }^{105}$ Edward F. Rimbault, The Old Cheque-book or Book of Remembrance of the Chapel Royal (London: Camden Society, 1872), 164-165.
} 
determination in overcoming these obstacles that life had thrown at him, and Anna appreciated these qualities in her youngest son. Anna, as a mother, was also able to see that Charles simply needed her more than Henry or Elizabeth did. ${ }^{106}$ In any case, Charles certainly seemed to have had a good relationship with his mother, particularly after Henry turned eighteen and began focusing his energies and attention on his own court, and predictably, even more so after Henry died and Elizabeth moved to her husband's home. As a younger son, Charles would have understood that his place in life was to provide a backup heir in case something should happen to Henry, and to make a powerful diplomatic marriage that might land him a kingship or other high position elsewhere in Europe.

Aside from experiencing some early animosity from some of his father's courtiers, ${ }^{107}$ Charles, like his sister Elizabeth, led a reasonably unremarkable childhood. By the time he was twelve, he had grown into a handsome and bright young man. He would always be small figured, a result of his infantile illnesses, but he had such excellent posture and carriage that he often seemed taller than he actually was. He had successfully learned to walk properly, and only a slight hesitation in his speaking patterns marked his earlier speech difficulties. ${ }^{108}$ Rather than seeming jealous of or spiteful towards his older brother, Charles seemed to love and admire him greatly, as expressed in an eloquent letter he wrote to Henry:

\footnotetext{
${ }^{106}$ Williams, Anne of Denmark, 97.

${ }^{107}$ Charles' earliest adversary when it came to title and position was one of his father's courtiers, Henry Howard, the Earl of Northampton. The Howards had been a dangerous family for some time in England, at least dating back as far as Henry VIII, when they provided the king with not one, but two of his brides that were later to be beheaded: Anne Boleyn and Katherine Howard. They were no less dangerous or ambitious by the time James took the English throne, and Northampton apparently took some offense at the five-yearold Charles being named Duke of York.

${ }^{108}$ Williams, Anne of Denmark, 158-159.
} 
Good Brother

I hope you are in good health, merry as I am, God be thanked. In your absence I visit sometimes your stable and ride your great horses that at your return I may wait on you in that noble exercise. So committing you to God, I rest

Your loving and dutiful brother

YORK. $^{109}$

Anna herself encouraged this brotherly love, since she had enjoyed a close bond with her own siblings and, in particular, with her brother Christian. It was reasonable that she would want this same sort of connection between her own two male children, especially since she would have understood how valuable such a connection could be when the two boys grew to adulthood and became European power players in their own right.

\section{Wife and Mother}

Anna's life as the queen consort of James was not anything remarkable in itself; however, she was faithful to her husband, even when they began living largely separate lives, and she provided him with children and heirs. Her marriage, like so many other royal marriages in early modern Europe, was not about love or friendship, but was at its core a business and political agreement. Given the available materials and sources, it seems as though Anna was not as upset about the lack of affection or goodwill between James and herself as she was about the matter of her children and their upbringing. This was certainly not the only point of contention between James and Anna, but it was perhaps the most significant one. Anna, perhaps more than any other queen consort before her, fought for the right to raise her own children, and it put her at odds with royal tradition and the king's prerogative.

\footnotetext{
${ }^{109}$ Manuscripts of the British Museum Library, Harleian 6986, f. 156; as quoted in Williams, Anne of Denmark, 104.
} 
Even though Anna's victory was late in coming, she did eventually win the war to raise Henry. While she never seemed to show as much affection or devotion towards her only daughter, Anna did seem to have Elizabeth's best interests at heart when she was negotiating her marriage and when she opposed the match to Count Frederick V. Anna was also involved in Charles' life from the very beginning, supporting Lady Carey when the latter refused to enact James' medieval methods of treating the young prince. Although Anna did not live to see Charles marry Henrietta Maria, it is likely she would have approved of his Catholic bride, the woman who would carry on Anna's theatrical tradition and take it even further.

Anna's life, however, was not limited to her relationship with her husband or her influence on her children. As will be seen in the following chapter, Anna would re-shape English court life and the ways in which women were permitted to interact with and exercise power through the court. 
Chapter Three: Anna as an Independent Political Entity

\section{The Separate Court of Queen Anna}

The cordial relations between James and Anna had been dissolving for some time before they arrived in England in 1603, beginning as early as the birth of Prince Henry in 1594 and the custody battle that ensued after the prince was placed in the care of the Earl of Mar. Disagreement over who should raise Henry, as well as differences in personalities, religious preferences and practices, and political ideals (for example, Anna favored a pro-Spanish policy, while James sought to maintain more of a balance) all combined to drive a wedge between the couple. In England, James and Anna grew even further apart as she began selecting her own household members and pursuing her own interests, such as the court masque, and eventually two completely separate courts would develop during their reign. It is difficult to pin down exactly when the court of Anna began to detach and solidify with an identity unique from that of the court of James. From the available sources it is known that Anna eventually set up her household at Somerset House, which she re-named Denmark House, in honor of her homeland and heritage, but it is unclear when this move was made and when it became Anna's permanent residence. ${ }^{110}$ Ethel Carleton Williams has argued that it was after the death of Anna's last child, Princess Sophia, and Anna's subsequent decision to have no more children, that the gap between Anna and James was sealed and the courts began to separate. ${ }^{111}$ While this certainly may have been part of the reason that Anna and James began to hold separate courts, it is unlikely that it was the only reason, or even the most crucial one. Like the emotional split between the pair, the physical separation and

\footnotetext{
${ }^{110}$ Ralph Dutton, English Court Life From Henry VII to George II (London: B.T. Batsford Ltd., 1963$), 104$.

${ }^{111}$ Williams, Anne of Denmark, 112.
} 
delineation of their courts was likely a process that was initiated by a series of disagreements and conflicts, such as Anna's continued disappointment at having her children removed from her care and James's insistence on retaining male courtiers that Anna found unpleasant at best and downright intolerable at worst.

It is a reasonably simple matter, however, to determine when the two courts split entirely. Interestingly enough, the final split came sometime after the development of a third, completely separate court: that of Prince Henry, which would have emerged sometime after his investiture as Prince of Wales in $1612 .{ }^{112}$ There are a few potential reasons for this timing. In the previous chapter, it was determined that Henry often had to act as an intermediary between his parents after he turned eighteen and set up his own court. Once he established himself in a separate court that was only tangentially reliant on that of James, Anna no longer had a consistent ally at James' court. Therefore, it would have been even more intolerable for Anna to remain there in the company of her husband and his favored courtiers. It is also important to remember that there was precious little to hold Anna's attention at James' court aside from Henry. Therefore, it could reasonably be surmised that since Anna had focused a great deal of time and energy on Henry and his kingly upbringing that her situation would change once Henry was no longer within her direct sphere of influence.

Anna was not the first queen consort to maintain her own court away from her husband's. Perhaps the most notable example in English history is that of the medieval English queen Eleanor of Aquitaine, whose life parallels that of Anna to some extent. In

\footnotetext{
${ }^{112}$ Strong, Henry Prince of Wales, 16-17. As alluded to in chapter two, it was after he established his own court that, according to Strong, Prince Henry found himself in the role of mediator between the two courts of his parents. Therefore, this illustrates clearly that by the time Henry was acting as Prince of Wales and by the time he had his own court, both of his parents also maintained their own courts as well.
} 
fact, of all the English queens that came before her, Anna probably had the most in common with Eleanor, although Eleanor had far more power than Anna would ever have. Eleanor herself had come to England from another land, in her case, France, where she ruled Aquitaine by right as the Duchess of Aquitaine and the Countess of Poitiers, having inherited this right from her father, William $\mathrm{X}$ of Aquitaine. ${ }^{113}$ Eleanor also lost her eldest surviving son at a young age. The boy's name was Henry, and Eleanor had been preparing him for the role of king of England, just as Anna had been preparing her eldest son. Eleanor's son Henry was just twenty-eight when he died, just as Anna's Henry had died at the relatively young age of nineteen. Perhaps the most useful similarity between these two queens, at least for this chapter, is that both established their own separate courts following a falling out with their husbands. Eleanor found herself on the wrong side of a political divide from her second husband, Henry II of England, and returned to Poitiers ${ }^{114}$ to look after her own interests and those of her eldest remaining son (who was still alive at the time). ${ }^{115}$

Of course, there are differences between the two queens consort as well: namely that Eleanor, who was able to rule in her own right in Aquitaine, was able to exercise much more direct power than Anna ever would. Additionally, unlike Anna, Eleanor also found herself in the unenviable position of being held captive by her own husband for twelve years, after having backed her sons in their attempt to overthrow her husband and their father, Henry II.

\footnotetext{
${ }^{113}$ D.D.R Owen, Eleanor of Aquitaine: Queen and Legend (Oxford; Malden, MA: Blackwell Publishers Inc., 1999), 14.

114 This in particular is a significant difference between Anna and Eleanor: Anna never returned to Denmark after she married James, despite how unhappy she may or may not have been or how unsatisfactory she may have found the marriage. Even if Anna had wanted to return to Denmark, she probably would not have had the authority to do so, whereas Eleanor did.

${ }^{115}$ Owen, Eleanor of Aquitaine, 67-79.
} 
Even though Anna may not have had the same kind of access to power that Eleanor would have had, she was able to establish her own court and household. One of the starkest markers of the difference between the courts of Anna and James (and even that of Henry) was the type of people each chose to appoint to their inner circles. Henry's court was made up of men who appreciated the same martial arts that the prince himself did, and they were nearly all steadfast Protestants. Many of these men were also welltraveled, and had an appreciation for fine art. The prince's court celebrated the shows of power and chivalry that had been popular during the Elizabethan age, and his desires to expand and conquer through warfare rather than diplomacy were well received by those courtiers who sought a return to the "golden age" that England had experienced under Elizabeth. ${ }^{116}$

James' court was, of course, markedly different: when he came to power in England following the death of Elizabeth, he retained the services of Robert Cecil, the son of Elizabeth's favored advisor and the man who was largely responsible for securing James' peaceful succession to the English throne. While Henry's court was known for its civility and decorum, James and his court tended to be more raucous: James enjoyed loud conversation, bawdy humor, and excessive drinking. While Henry spoke of war, James sought unification of the great Christian powers in Europe. He embraced many members of the Catholic Howard family and their faction, including Lord Henry Howard. ${ }^{117}$ James also seemed to exercise more religious tolerance within his own court than did his eldest

\footnotetext{
${ }^{116}$ Coke, A Detection of the Court, 61.

${ }^{117}$ Akrigg, Jacobean Pageant, 34-35.
} 
son, so long as his Catholic courtiers were discreet in their practice and quiet about their beliefs. $^{118}$

Anna's own court, when it developed, would reflect both similarities and stark differences with the courts of her husband and eldest son. Like her husband, Anna accepted both Catholics and Protestants into her court and household. ${ }^{119}$ Some of her most favored ladies were Lucy, Countess of Bedford, Lady Anne Clifford, Lady Penelope Rich, and Lady Jean Drummond, women who were themselves somewhat varied in their religious preferences. James had initially sent his own delegation of nobles to meet Anna on her way out of Scotland in 1603. He intended to have these persons fill her household. He had appointed Sir George Carey as her chamberlain, and had sent the Countesses of Worcester and Kildare and the Ladies Scrope, Rich, and Walshingham. Despite James's attempts to dictate Anna's household, however, Anna retained only Lady Bedford and Lady Harington from his selections and made them ladies of the bedchamber. She flatly refused to accept the service of George Carey, and instead insisted on retaining the services of John Kennedy as her chamberlain. James feared, perhaps legitimately, that Anna's loyalty to her friends and countrymen would reflect badly upon himself in England. Anna, however, did not seem to have had any such qualms, and refused to bend to James's wishes regarding the members of her household. ${ }^{120}$ By taking control of her own household, Anna was already setting a precedent for the later creation of her own court after she made the move to England.

\footnotetext{
${ }^{118}$ Strong, Henry, Prince of Wales, 26. Henry, meanwhile, found the entire Howard clan distasteful, and refused to allow them entrance to his own court.

${ }^{119}$ Alphons Bellesheim, History of the Catholic Church in Scotland, Vol. III (Edinburgh; London: Blackwood, 1890), 347.

${ }^{120}$ Ibid., 76.
} 
Anna was making it clear that she was willing to make her own decisions about whom she was willing to associate with, and that she was capable of operating independently of James when fashioning her household and, later, her court.

Anna's refusal to allow James to dictate her household can be interpreted as a move of shrewd intelligence: having been raised in a royal household, Anna understood that accepting those women whom James had chosen for her court would be disastrous for her. Any woman selected by James would owe her position, and therefore her loyalties, to James first and Anna second. Consequently, had Anna not taken a genuine liking to the Countess of Bedford or Lady Harrington, she would have had no qualms about rejecting all of the candidates James had put forward. Also, by surrounding herself with women of varying religious beliefs, Anna threw up a defense against those people who would latch onto her Catholicism and accuse her of popery. By selecting her own courtiers and, eventually, crafting her own court, Anna was able to build a network that was loyal to her, and that would advocate for her interests.

This example also shows that Anna knew when she could legitimately go directly against the wishes of her husband: rejecting the appointees of the King was a risky move, since James could have dismissed just as easily the courtiers Anna had selected for herself and insist that she employ his choices. There was also an inherent political danger, since Anna could have chosen women that would have elicited extreme and volatile reactions from the men advising James like Robert Cecil. Anna had to have had a shrewd understanding of court politics in order to put together her new English court and household successfully. 
Securing a position at court, whether it was at the court of James, the court of Henry, or the court of Anna, opened up a world of opportunities and privileges for noble Englishmen and women. What was even more valuable, however, was to be named a member of a royal household. Anna's household was no exception: in her 1605/1606 household, the ladies were selected from those women who were related to members of the king's household, although Anna herself still retained the final say regarding who was and was not selected for these intimate positions. For example, Catherine, the Countess of Suffolk and the wife of the Lord Treasurer, Thomas Howard, Earl of Suffolk, was selected as the Keeper of the Queen's Jewels and Lady-in-Waiting. Elizabeth Lady Carey was named Keeper of the Sweet Coffers, and Mistress Anne Carey was named a maid of honor. Elizabeth was the wife of Sir Robert Carey, and Anne was his daughter. Sir Robert Carey had been the man who had ridden ahead of the official delegation to inform James of Elizabeth I's death. Another maid of honor, Mary Middlemore, was the sister of the equerry to King James. ${ }^{121}$ The courts and households of Anna and James, then, despite being separate, occasionally intersected and were still bound by a complex web of patronage. Anna was able to select and favor her own courtiers, and therefore influence who was included with this web, but at its heart this system still included both monarchs and their circles. This connection, no matter how subtle it may have been at times, meant that Anna could exercise some degree of influence within the greater English court as a whole, even beyond her own household. This will be seen particularly in Anna's involvement in the rise of George Villiers, as well as her involvement with Lady Anne Clifford, both of which will be covered later in this chapter. Whomever Anna introduced

\footnotetext{
${ }^{121}$ Linda Levy Peck, Court Patronage and Corruption in Early Stuart England (Cambridge; London: Unwin Hyman, 1990), 69.
} 
into this complex system would, theoretically, be acting and moving according to her will and interests, assuming that their personal loyalties were not tempered by their husbands' loyalty to James. ${ }^{122}$

\section{Anna's Loyalties}

Being selected as a member of Anna's inner circle at court was more than just a political coup. The advantages in securing her favor and remaining in her good graces become evident when examining her relationships with several of her courtiers, both male and female, and in both Scotland and England. Anna's loyalties, and her consequent actions, were by no means a guarantee of success on the part of whomever she was championing at the time, since Anna was still only a queen consort, and therefore still had to answer to the whims and laws of her husband. There are, however, several examples of Anna intervening on behalf of her courtiers and successfully winning her case. What is more important when studying these events is not to look at whether or not Anna was successful, but rather to examine how Anna went about exercising political authority.

The first example of Anna's intervention in politics is seen during the Ruthven/Gowrie Plot in Scotland in 1600, and ended with mixed success for Anna and her friends. The events surrounding this particular episode in James' reign are clouded and uncertain; only a few verifiable facts seem to have survived. It has been established that on 5 November 1600, King James had gone hunting near his Falkland estates. After the hunt, he went to the house of the Earl of Gowrie with Alexander, Master of Ruthven,

\footnotetext{
122 There were, occasionally, instances when a woman would go to Anna for aid even if her husband was loyal to James. The most notable instance of this is the example of Lady Anne Clifford, who will be discussed later in this chapter.
} 
who was the younger brother of the earl. By the end of the evening, both the Earl of Gowrie and the Master of Ruthven were dead at the hands of the king's men. This is where the knowledge of events that is accepted by scholars ends, and speculation begins. There was no clear reason established as to why James ordered these young men killed, although there was certainly reason for enmity between the Earl of Gowrie and the king. Gowrie was the grandson of the assassins of David Rizzio, the secretary of Mary, Queen of Scots. He was also the son of one of the leaders of the unsuccessful Ruthven raid that had put James in the hands of his enemies as a child. Gowrie was also popular with the Scottish people, who had gathered to greet him as he re-entered Edinburgh after a sojourn in England, and therefore, James may have seen him as a threat to his sovereignty. Finally, and perhaps most significantly, James owed the Earl a significant sum of money. On the other hand, James seemed to like the Master of Ruthven a great deal. Alexander was young, handsome, and an excellent huntsman, all qualities that James valued in his courtiers. Despite his ancestor's unsavory past regarding the Scottish royal family, the young man had been a favorite of the king at court. ${ }^{123}$

The official story that James and his council put out after the deaths of the Earl of Gowrie and the Master of Ruthven had elements that seem to be within reason, and others that seem to be absurd. James claimed that the Master of Ruthven had taken him aside during the hunt and told him a tale involving a cloaked mystery man and a pot of gold. Ruthven allegedly had the mysterious man detained at the estates of his brother, and entreated the king to come investigate. The king agreed, but when he was led deeper into the house, with Ruthven locking the doors behind them, he found himself trapped in a

${ }^{123}$ Willson, King James VI and I, 126-127; J.D. Mackie, A History of Scotland (New York: Penguin Books, 1964), 184-185. 
turret room with Ruthven and his chamberlain. Ruthven then supposedly declared that the king was the prisoner of Ruthven and Gowrie in retaliation for the execution of their father. The Gowrie brothers' father, the previous Earl of Gowrie, had initially been pardoned for his role in the infamous Ruthven Raid; however, he was executed as a traitor shortly thereafter based on other charges. ${ }^{124}$ When Ruthven left to fetch Gowrie, the chamberlain told James that he too had been imprisoned, and that he would do anything he could to help James. The pair eventually pried a window open, and James called for help. Sir John Ramsay, a young man in the king's service, killed Ruthven by sword in the stairwell as the latter was attempting to flee and, when Gowrie arrived, Ramsay ran him through as well. ${ }^{125}$

That James was gullible enough to fall for the "pot of gold" story is unlikely, given his distaste for superstition and his reputation as an intellectual. What is more plausible is that he liked and trusted the Master of Ruthven and had no reason not to follow him back to the house of his brother, for whatever reason. That he found himself captured by his Scottish nobles (again) seems a bit more reasonable, especially since the perpetrators were the direct descendants of the man who had pulled a similar stunt when James was a child. Ultimately, it did not matter if any or all of James' entire story made sense, because he was the king and his word was still law. Even if the Master of Ruthven or the Earl of Gowrie had not been killed that day, they likely would have met the same fate as their father and been executed for treason. Both parties had motive to see the other harmed or dead: James to discharge his debt and Gowrie to avenge his father, and yet before this incident they had seemed to be friendly to each other, possibly because the

\footnotetext{
${ }^{124}$ Mackie, A History of Scotland, 170.

${ }^{125}$ Akrigg, Jacobean Pageant, 10-12.
} 
Master of Ruthven was exactly the type of handsome, athletic young man that James liked to surround himself with. ${ }^{126}$ As a monarch, James was always going to have to contend with plots against his well-being by malcontents and opposing factions, although most of them would certainly not be of this magnitude. ${ }^{127}$

During the time that these events unfolded (late 1600/early 1601), the nineteen year old Beatrix Ruthven was a Lady-in-Waiting to Anna. In the aftermath of the plot, James summarily dismissed Beatrix from Anna's service without bothering to consult Anna herself (and it is unlikely he felt that he had any need to do so). Anna had few friends in her new homeland, and she sincerely liked Beatrix. However, Anna was still relatively new to Scotland, and she had very few options for fighting what she perceived to be a great injustice on the part of her husband, namely his removal of Beatrix from her household. James Melville, a Scottish courtier who was no particular supporter of Anna, noted that:

If ever the Queen found that the King had, by wrong information, taken a prejudice against any of his faithful subjects or servants, she always exerted herself to obtain information of the truth that she might speak with the more firmness in their favour. ${ }^{128}$

What Anna could do was take advantage of James's ever present fear about the line of succession and his bid for the English throne. Following Beatrix’s dismissal, Anna remained in her bed for two days, refusing to speak, eat, or dress until Beatrix was returned to her service. James, contrary to his usual behavior, did not admonish his wife for her behavior. Instead, he attempted to distract and appease her by hiring a famous

\footnotetext{
${ }^{126}$ Willson, King James VI and I, 127-129.

127 The most historically notable, plot of course, being the ill-fated Gunpowder Plot led by Guy Fawkes on the 5 November 1605, which not only targeted James, but Henry and Charles as well.

${ }^{128}$ Sir James Melville, T. Thomson, ed., Memoirs of His Own Life by Sir James Melville of Halhill, 1549. 1593 (Edinburgh: Bannatyne Club, 1827), 361.
} 
(and expensive) French acrobat that Anna liked to try and entertain her, thus coaxing her out of bed. ${ }^{129}$

Anna was not moved by James' response. Worse still, at least to James's mind, was the fact that Queen Elizabeth found James's account of the events of the Ruthven/Gowrie affair absurd and refused to believe them, as did the French monarchy, whom James was still trying to court as a potential ally or future marriage partner for his children. James did get his way with the Scottish Parliament, however, which declared the Earl of Gowrie and the Master of Ruthven traitors to the crown. Their bodies were hanged, drawn, and quartered, and the name of Ruthven was stricken from the records. James's actions against the corpses of Ruthven and Gowrie were not enough to deter Anna from her support of Beatrix, however, and Anna refused to give up her efforts to reinstate Beatrix to her service. ${ }^{130}$

In September 1602, with the help of Lady Paisley and Lady Angus, Anna had Beatrice brought to her apartments at Holyrood and hidden there. When James found out, he launched a full investigation into Anna and her household, but eventually he was forced to admit that there was absolutely no evidence against Anna, Beatrix, or anyone else in the queen's household. Beatrix was granted a pension of $£ 200$ and re-instated into Anna's service. ${ }^{131}$

At this point, it is worth exploring the question of why Anna felt the need to take such drastic, and frankly risky, actions in order to try and help Beatrix Ruthven.

\footnotetext{
${ }^{129}$ Ibid., 326-327. The acrobat was reported to have cost James $£ 3336 s 8 d$, which was a significant sum at the time.

${ }^{130}$ British History Online, Calendar of State Papers Domestic, August - September 1603, last date updated: 2011, <http://www.british-history.ac.uk/report.aspx?compid=14988>.

${ }^{131}$ Ibid.
} 
Emotional concerns aside, Anna had little practical reason to retain Beatrix's services. Noblewomen were not exactly a rare commodity, and a suitable replacement surely could have been found. This could be used as evidence to prove that Anna did sincerely like Beatrix and did not wish to see her ruined because of the actions of James; however, this instance also provided Anna an opportunity to test her own boundaries and power within her new court. As a queen consort, Anna did not have the authority to reverse her husband's decision to dismiss Beatrice. Consequently, she had to find another way to convince him to bring her back himself. This was a tactic that Anna would have learned from watching her mother, whom had often had to find alternative ways to exercise power at the court of her son, King Christian IV. ${ }^{132}$

The fact that James first tried to placate Anna with an expensive acrobat shows that he was not interested in fighting this particular battle. He could have tried to wait Anna out. He could have threatened her with any number of royal punishments, or he could have divorced her, and yet he made an effort to bribe her instead. James had to take into account the fact that if he did not appease her, Anna would be uncooperative when it came to conceiving more children. There was also his image to consider: a married king had the potential to produce legitimate heirs, whereas a divorced king brought with him a host of potential problems regarding the succession. James's attempts at smoothing over the situation, however, probably actually strengthened Anna's resolve to push the matter further, since she then knew that James did not want a fight. Once Anna realized that James was not going to punish her for her behavior, she had no reason not to continue her course of action and try to have Beatrix re-instated to her household. This was the first,

\footnotetext{
${ }^{132}$ Williams, Anne of Denmark, 16.
} 
but by no means the last, notable instance of Anna's standing up to her husband on behalf of one of her courtiers.

Anna's next courtly intervention, which occurred after she had moved to England, was not as successful. Sir Walter Raleigh, a brilliant man and a seasoned soldier, was a favorite not only of Anna, but of her son Henry as well. Roy Strong, who has written a biography of Henry, suggests that it was actually Anna who told Henry about Raleigh in the first place. The young prince would carry on a correspondence with the famed navigator and sailor for the rest of his life, and would become his greatest patron. Raleigh's largest undertaking, his unfinished History of the World, was dedicated to Henry. ${ }^{133}$ Henry, with his own inherent love of all things nautical, tried on multiple occasions to plead Raleigh's case to his father, and opposed James outright when the king made an attempt to seize Raleigh's land after his arrest. Raleigh, who had once been celebrated as a champion of Elizabethan England, had been placed in the Tower of London by King James on 19 July 1603, charged (thanks to evidence and charges that were almost certainly fabricated or manipulated) with complicity in the Bye Plot against the King. ${ }^{134}$ Raleigh represented everything that James was trying to suppress, or at least avoid: he was very anti-Catholic and very anti-Spanish, and he was keen on re-opening the war between England and Spain. These ideas and sentiments were ones that Henry

\footnotetext{
${ }^{133}$ The book ended at 167 B.C.E, far short of its initial goal, when Raleigh stopped working on it shortly after Henry's death.

${ }^{134}$ The Bye Plot of 1603 was concocted by a cadre of Catholic priests and Puritan leaders that aimed to kidnap James and force him to allow religious freedom for their respective denominations. Given Raleigh's intense distaste for all things Catholic, it seems absurd in the extreme to suggest that he would have played any role in the plot. For more information about the Bye Plot, the evidence that was used against the conspirators, and the repercussions for James and his court, see Mark Nicholls, "Treason's Reward: The Punishment of Conspirators in the Bye Plot of 1603," The Historical Journal, 38, no. 4, (1995): 821-842.
} 
himself shared, and he once remarked that " None but my father would keep such a bird in a cage. $", 135$

Though imprisoned by James, Raleigh enjoyed a relative degree of freedom during his time in the tower, and was allowed to maintain an herb garden, which he used to grow the plants with which he later experimented. Having heard a positive review of Raleigh's Balsam of Guiana cordial from the French ambassador's wife, Anna herself requested that Raleigh prepare a sample for her. ${ }^{136}$ This began a friendship between Anna and Raleigh that would persevere until the time of Raleigh's death. Anna was apparently so impressed with Raleigh that when her brother, King Christian IV of Denmark, came to England for an official visit, Christian himself implored James to allow Raleigh to go free and relocate to Denmark, where Christian would grant him an admiralship in the Danish navy. ${ }^{137}$ Unfortunately for Christian, Anna, and Raleigh himself, James refused to grant Raleigh his freedom. Meanwhile, Prince Henry had begun visiting Raleigh in the tower as well, and it was at this time (somewhere around 1608) that Henry became Raleigh's other great supporter, alongside his mother. It was Henry who prevented Raleigh's estates at Sherborne from being handed over to James' current favorite, Sir Robert Carr, instead holding the lands himself under the assumption that he would return them to Raleigh at such a time as Raleigh should once again find himself at liberty. Before he could secure Raleigh's release, however, Henry died. It is interesting to note that, shortly before

\footnotetext{
135 Roy Strong, Henry, Prince of Wales, 50-52.

${ }^{136}$ Robert Lacey, Sir Walter Raleigh (Forge Village, MA: Murray Printing, 1973), 322.

${ }^{137}$ Ibid., 323.
} 
Henry's death, Anna had insisted upon administering Raleigh's cordial to her son, although Raleigh himself said that it was too late to do any good. ${ }^{138}$

Despite Henry's death in 1612, Anna remained a staunch supporter of and friend to Raleigh. Why, though, did Anna take a liking to him in the first place? Raleigh's personal hobbies stood in almost direct opposition to those of Anna. While Raleigh enjoyed navigation and ships, Anna had not been close to the sea and had not been on any sea-faring vessels since her traumatic first journey to Scotland. Raleigh was a man of science, whereas Anna preferred the arts. Yet Anna, though she may not have always understood Raleigh's methods or formulas, certainly understood that his was a brilliant mind, as is evidenced by her request for a sample of his Balsam of Guiana cordial. Anna valued this quality in Raleigh as she did in others, and this was where their friendship began. Anna would have also seen in Raleigh a more suitable male role model for her sons than was her husband. James was certainly an intellectual, but he lacked the charisma, charm, and courage that the English people celebrated in Raleigh. Once Henry had established a firm friendship with Raleigh, Anna's own support of the man would have solidified as well. Interestingly enough, Anna's alleged Catholicism did not seem to affect her friendship with Raleigh or her support of him, nor did it seem to foster any ill will on his part towards her. This could simply be that Raleigh knew that he needed as many allies at court as he could muster, and he understood that it was in his best interest to stay in Anna's good graces. In any case, both Anna and her son were adamant in their arguments with the king that Raleigh should be pardoned and released.

${ }^{138}$ Ibid., 324. 
Henry's death put an end to any possibility that Raleigh would be granted a release any time in the immediate future, but it did not completely wipe out the possibility that he would be released from the tower eventually. After all, he still had Queen Anna on his side. Unfortunately, Raleigh apparently did not have the patience to spend any more time in the tower. On 9 August 1618, he attempted to escape, but failed. ${ }^{139}$ Anna again attempted to persuade James to release Raleigh. This time she tried to reach her husband through his newest favorite, George Villiers, the Duke of Buckingham (a man that Anna herself had helped place in this powerful position, as will be seen later): "If I have any power or credit with you, I pray you let me have a trial of it at this time in dealing sincerely and earnestly with the king that Sir Walter Raleigh's life may not be called in question." ${ }^{140}$ For whatever reason, Buckingham ignored the letter and any loyalty he may or may not have felt towards his queen. Raleigh's conviction for treason and the death sentence he received as a result of his trial on 28 October 1618 led to his execution by beheading on the following day. ${ }^{141}$

Anna, despite her best efforts, had not been able to save Raleigh. Of course, had Henry lived, the situation would most likely have played out differently, but as he did not, there is little use in entertaining "what-if" scenarios. By the time Raleigh was executed, Anna and James not only had separate courts but were leading largely separate lives, and it would seem as though in this case Anna, rather than having direct access to her husband, had to attempt to navigate the same channels of favorites and courtiers as her mother had in Denmark. Anna had lost one of her greatest bargaining chips when she

\footnotetext{
${ }^{139}$ Ibid., 369.

${ }^{140}$ The Monthly Review, or Literary Journal: From January to June, inclusive. By Several Hands, Vol. 68, (London: Printed for R. Griffiths, 1783), 125.

${ }^{141}$ Lacey. Sir Walter Raleigh., 374-375.
} 
stopped carrying children, and therefore had largely lost her ability to intervene directly when it came to dealing with her husband.

One of the more puzzling instances of Anna's favor and patronage pertains to Lady Arbella Stuat. Arbella was the daughter of Elizabeth Cavendish, who was in turn the daughter of Elizabeth Talbot, the wealthy Countess of Shrewsbury, and Charles Stuart, the son of Lady Margaret Douglas, who was a granddaughter of Henry VII. ${ }^{142}$ The pair had married without the permission of the queen, but received little remonstrance for their disobedience. Nevertheless, Arbella herself was born into a highly unenviable situation. By virtue of her father, Arbella was a legitimate (albeit reasonably far removed) heir to both the Scottish and English thrones. This would automatically put her under the suspicious eye of Queen Elizabeth I, who was always wary of potential usurpers to her throne. Consequently, Arbella's life would never be easy, and she would have had even less freedom than her noble counterparts, since Elizabeth was careful to make sure that Arbella never gained too much power or influence. Both of Arbella's parents died when she was very young, and Elizabeth I and James himself managed to seize and divvy up Arbella's entire inheritance, leaving the child and her guardians with a pension of only two hundred pounds. This sum was far less than could have been reasonably expected to support Arbella in the noble manner befitting a potential royal heir, but there was nothing to be done about it. ${ }^{143}$ Arbella, in fact, had little to do with the politicking that surrounded her person, at least during her early life. It was not until after Elizabeth had died and James had taken the throne in 1603 that Arbella's life took a turn for the better. As soon as she acknowledged James as the rightful king of England, James (on the advice of

\footnotetext{
${ }^{142}$ Lady Arbella Stuart, Sara Jayne Steen, ed., The Letters of Lady Arbella Stuart, 13-16.

${ }^{143}$ Ibid.
} 
Robert Cecil) released Arbella from official custody, where she had languished for years, and invited her to join him at court. She was granted an allowance of eight hundred pounds a year, and she was made a member of the court of Queen Anna. ${ }^{144}$

Despite the kindness she received at Anna's court, Arbella found occasion to look down upon her royal benefactor. She was scandalized by the activities in which Anna and her ladies participated, although not so scandalized that she refused to participate, herself, when invited:

Whilest I was at Winchester theare werre certein childeplayes remembred by the fayre ladies. Viz. I pray my Lord give me a Course in your park. Rise pig and go. One peny follow me. etc. and when I am to Court they weare <as > highly in request as ever cracking of nuts was. so I was by the mistresse of the Revelles [Anna] not onely compelled to play at I knew not what for till that day I never heard of a play called Fier. but even perswaded by the princely example I saw to play the childe againe. ${ }^{145}$

Arbella may have been condescending regarding Anna's private pastimes, but she also seemed to understand that she had a good life at Anna's court and in her household, and she was known to point out Anna's more positive qualities to others on occasion. Arbella also had more in common with the Danish queen than she may have realized. Each woman had recently undergone a significant upheaval in her life: for Arbella, it was the allegation that she was at the center of The Main Plot $^{146}$ in 1603 , which had aimed to place her on the throne in place of James. ${ }^{147}$ Anna's own traumatic event, of course, had been the custody battle for Henry and her subsequent miscarriage.

\footnotetext{
${ }^{144}$ Sarah Gristwood, Arbella: England's Lost Queen (Boston, MA; New York: Houghton Mifflin Company, 2003), 204-207.

${ }^{145}$ Lady Arbella Stuart, Sara Jayne Steen, ed., The Letters of Lady Arbella Stuart, 193.

${ }^{146}$ Nicholls, "Treason's Reward," 825-826. The Main Plot, which actually ran a parallel course to that of the Bye Plot, was a very simplistic affair: the alleged conspirators, funded by Spain and led by Henry Brook, Lord Cobham, intended simply to kidnap James and his sons and either remove them from power peaceably or, if that failed, kill them. Arbella Stuart would then be placed on the throne in her cousin's stead.

${ }^{147}$ Gristwood, Arbella: England's Lost Queen, 211.
} 
Both women were also intensely proud of their royal heritage; a heritage that James was eager to dismiss in both cases. Finally, Arbella and Anna were close in age. Anna had a tendency to appoint women of her own age to her court and household, and Arbella fell within that group. Anna was twenty-nine at the time of Arbella's appointment to her court; Arbella was twenty-seven. ${ }^{148}$ Arbella was occasionally appalled by what she perceived to be a lack of manners and civility at the court of her cousin, and she acknowledged that Anna was a much more fitting picture of royal bearing than the king:

But if ever theare weare such a Vertu as courtesy at the Court I marvell what is becomm of it? for I protest I see little or none of it but in the Queen who ever since hir comming to Newbury hath spoken to the people as she passeth and receiveth theyr prayers with thanckes and thanckfull countenance... $^{149}$

What could Anna have seen in Arbella that made her so inclined to welcome her with seemingly open arms into her inner circle? Arbella was, after all, a close relative of James and should therefore have been more inclined to promote his interests than Anna's. Arbella's kinship with James, as well as the fact that she owed her position largely to him and not Anna, should also have meant that her loyalties would have been to him instead of the queen, yet this does not seem to have been the case. Arbella, despite her qualms about Anna and her court, was loyal to the queen. As to why Anna took Arbella under her wing, the answer may be found in Anna's own relationship with James. Despite living virtually separate lives in England, Anna still understood James' politics better than many people, since she had been with James for longer than many of his English courtiers, and because of this she could see that James would never truly have Arbella's best interests at heart. Arbella herself seems to have developed a

\footnotetext{
148 Ibid., 227-229.

${ }^{149}$ Lady Arbella Stuart, Sara Jayne Steen, ed., The Letters of Lady Arbella Stuart, 184.
} 
loyalty to and certain affinity for Anna; it would be to Anna that Arbella would appeal when her situation took a turn for the worse.

Meanwhile, Arbella's life finally seemed to be falling into place, despite her being an "old maid" by the standards of her time. Then, at four o'clock in the morning on 22 June 1610 Arbella made a terrible decision that echoed one made by her aunt Mary, Queen of Scots: she married for love (or at least personal gratification) instead of according to political convenience or royal decree. As a royal cousin, Arbella had fairly significant leeway when it came to James; in fact, James was fully prepared to allow her to marry any faithful subject of his, with one notable exception: William Seymour who, like Arbella, claimed royal blood. James would not allow any match that could possibly produce a legitimate (and dangerous) potential heir to his throne. In an instance that seems out of character for the intelligent Arbella, she had disobeyed her cousin's mandate and began a courtship with Seymour sometime in February 1610. James discovered the affair, and ordered the two separated. Undeterred, the pair married clandestinely. ${ }^{150}$ It is unknown how Anna reacted to this development: having been raised as a princess in a royal household, Anna would have understood fully that the choice of one's marriage partner was not a luxury afforded to women, and even noblemen were restricted by the court politics at any given time. While Anna certainly could have advocated for certain matches for Arbella, and perhaps even supported a match with Seymour, her consistent promotion of her son Henry's royal prerogative indicates that she would have prioritized the protection of her own royal line rather than risk the birth of a potential claimant by

${ }^{150}$ Akrigg, Letters of King James VI and I, 320. 
Arbella. ${ }^{151}$ Anna respected Arbella's royal lineage, but Arbella was not queen; Anna was. Anna had gone to great lengths to promote the interests of her sons, first Henry and then Charles in regards to their future kingship, and therefore she would not have actively supported a match that would threaten that future.

Arbella herself was not so naive as to think that her unauthorized marriage would have no repercussions, and she asked Anna, through Anna's lady-in-waiting Jean Drummond, to intercede on her behalf with James in a letter, most likely written during the summer of 1610. Lady Drummond replied to Arbella's request, although perhaps not as satisfactorily as Arbella may have hoped:

Bot this day her majestie heth sin your ladyships letter, her majestie sayes that when she gaive your ladyships pettition and letter to his majestie, he did taek et wellanuch [well enough] bot gaive no uther ansur then that yee had etne of the forbidne trie, this was all her majestie comands me to say to your ladyship in this porpos, bot withall did remember her cyndly to your ladyship and sent you this litle tokne in wotnes of the contineuence of her majesties favor to your ladyship. ${ }^{152}$

Despite Anna's efforts, in January 1611 James decided to ship Arbella to the north of

England while keeping Seymour close at hand in London. James intended to hand over

Arbella to the custody of the Bishop of Durham, to whom he wrote this letter in March

1611, where Arbella would once again be under constant surveillance:

Whereas our cousin the Lady Arbella hath highly offended us in seeking to match herself without our knowledge... forasmuch as it is more necessary for us to make some such demonstration now of the just sense and feeling we have of so great an indignity offered unto us as may make others know, by her example, that no respect of personal affection can make us neglect those considerations wherein both the honour and order of our government is interested. ${ }^{153}$

\footnotetext{
${ }^{151}$ A marriage between Arbella and the young Prince Charles would have been completely out of the question for Anna, who did not approve of marriage between first cousins.

${ }^{152}$ Lady Arbella Stuart, Sara Jayne Steen, ed., The Letters of Lady Arbella Stuart, 292.

${ }^{153}$ Akrigg, Letters of King James VI and I, 320-321.
} 
Before Arbella could be moved, however, she and Seymour attempted to escape via ship to the continent on 3 June 1611. Seymour succeeded, but Arbella did not, and was placed in the Tower of London. ${ }^{154}$

It was during her imprisonment that Arbella's life began to fall apart in earnest. Despite her long confinement, she was never actually charged with a crime, nor was she ever brought to trial. Her aunt, Mary Talbot, who was charged with assisting in Arbella's attempted escape, was fined the exorbitant sum of twenty thousand pounds and placed in the tower with her niece. Then, Arbella became very sick. It is uncertain exactly when Arbella fell ill, but in the autumn of 1614 her body and her mind began failing. In a last show of defiance, she refused all medical attention. On 25 September 1615 , she died. ${ }^{155}$ After Arbella's death, James refused her a public funeral as would have befitted her prior status as a "member of the family." There was no public response to her death, since no one was particularly eager to cross James now that he had fully established himself as the power and authority in England. He did, however, have her body interred at Westminster Abbey, alongside her aunt, Mary Queen of Scots and her second cousin, Prince Henry. Once again, Anna tried to intercede on behalf of the memory of her ladyin-waiting: Anna asked James to allow the court to enter into a period of mourning for Arbella. James refused. ${ }^{156}$

Although James now enjoyed relative security in his position, it is likely that this is another instance of his concern for the public's perceptions of him. The last thing that James would have wanted was to have the English people rally around the figure of

\footnotetext{
${ }^{154}$ Ibid.

${ }^{155}$ Ibid., 350-352.

${ }^{156}$ Lady Arbella Stuart, Sara Jayne Steen, ed., The Letters of Lady Arbella Stuart, 101.
} 
Arbella and turn her into some sort of martyr. Anna could not persuade her husband to forgive Arbella during her lifetime; she had no better luck after Arbella had died. There are at least two reasons why Anna would have wanted to allow the court to go into public mourning. Since Anna had been friendly to Arbella, and since James himself had initially made such an effort to make her a member of the family, the queen would have genuinely wanted an opportunity to grieve for a woman that she personally had accepted into her court. Also, given Anna's noted concern for the court's public image and the importance she placed on courtly decorum and procedure (as reported in one Arbella's own letters noted above), she feared that not entering a period of mourning would reflect poorly on the court.

Despite being unable to save either Raleigh or Arbella, Anna was still not without power and influence. One of the most crucial examples of this is the case of Lady Anne Clifford, one of Anna's ladies-in-waiting. Lady Anne was the daughter of George Clifford, $3^{\text {rd }}$ Earl of Cumberland, and Countess Margaret Russell. Through her father she was related to one of the oldest and most noble families of England, since the Cliffords could trace their lineage to before the Conquest. It was her father or, more precisely, his death and his will that would bedevil Lady Anne for many years and put her at loggerheads with King James himself. Through her mother, Anne was related to the earls of Bedford, and was a niece of Lucy Russell, Countess of Bedford, who was Anna's most favored courtier. However, her high and noble birth was not what made Lady Anne unique to historical remembrance; nor was it her reasonable intelligence or her beauty. Rather, it was her handling of the increasingly bad circumstances that she found herself 
in that secured her a place not only in her own story, but that of Queen Anna. ${ }^{157}$ Lady Anne was eighty-six years old when she died on 22 March 1676, and she had lived to see the reigns of Elizabeth I, James I, Charles I, Lord Protector Oliver Cromwell, Lord Protector Richard Cromwell, and Charles II. She not only witnessed the momentous events of these eras, but also found herself at the center of some of them. ${ }^{158}$ Consequently, her life provides an interesting, and relatively complete, case study regarding the life of an early modern English noblewoman.

As a woman (albeit a noblewoman), Lady Anne consistently found herself at the mercy of others: first her guardians, then two equally unsatisfactory husbands, and finally Anna. Yet despite the victimhood that was pressed upon her, Lady Anne, with the help of Queen Anna, was able to win a fairly significant victory for herself, and she stands out in this time period as a woman of intelligence and character, much like the monarch in whose court she served. Lady Anne first made the acquaintance of Anna during the latter's progress from Scotland into England in 1603. The young Anne was with her mother who, as a noblewoman of some importance, was present to greet the Scottish queen when she arrived in England:

Thither came my Lady of Bedford who was so great a woman with the Queen as everybody much respected her, she having attended the Queen out of Scotland. The next day we went to Mr Griffin of Dingley's which was the first time I ever saw the Queen and Prince Henry, when she [Anna] kissed us all and used us kindly... That night we went along with the Queen's train, there being an infinite number of coaches... ${ }^{159}$

\footnotetext{
${ }^{157}$ Richard T. Spence, Lady Anne Clifford: Countess of Pembroke, Dorset, and Montgomery (1590-1676) (Phoenix Mill, Gloucestershire: Sutton Publishing, 1997), 1.

${ }^{158}$ Lady Anne Clifford, Isabella Barrios, Vita Sackville West. The Diary of the Lady Anne Clifford (1590 167 , iv.

159 Ibid., 5.
} 
Anne could not have known it at the time, but she had just met the woman who would become her most valuable ally at court.

When Lady Anne's father died on 30 October 1605, he left a will that would cause so many complications and such great confusion that it is difficult to sort out even today. Due to a series of clauses and conditions regarding heirs and the possession of property, Lady Anne found herself having to fight for the lands and titles that rightly should have been hers, particularly the sherrifwick of Westmoreland. The situation was not made any easier for Lady Anne by her first husband, Richard, Earl of Dorset, who encouraged his wife to accept the King's settlement of her inheritance in exchange for a grant of money from James. Although it would have come from her inheritance, this money would not have gone to Lady Anne. Instead, it would have been dispensed to her husband, who most likely would have used it to fund his extravagant court lifestyle. ${ }^{160}$ As the wife of an important earl, Lady Anne was at court often, and she became close friends with Princess Elizabeth, who would continue to correspond with Lady Anne after she married and left England. Anne's life seemed, at that moment, to be happy. In 1615 , however, there was a falling out of sorts between her and her husband: to advance his own position in James' court, Dorset wanted Anne to accept a settlement of her father's estates. As noted above, the arrangement would have settled decidedly out of Lady Anne's favor. Matters were made even worse in May 1616 when Lady Anne's mother, the Countess Margaret, died. Margaret had been a fierce defender of her

\footnotetext{
${ }^{160}$ Spence, Lady Anne Clifford, 60. Dorset was a notorious gambler and philanderer, and is recorded as having affairs with multiple noblewomen, including Elizabeth Broughton, Lady Penistone, and possibly Lady Venetia Stanley. He also had several illegitimate children. Aemilia Lanyer, known later for her writing, described him as “'beauteous." Despite her husband's many infidelities, Lady Anne remembered him kindly in her later years, noting that he was an excellent father and a kind, if not altogether faithful, husband.
} 
daughter's rights, and upon her death Anne found herself under even more intense pressure from the likes of the Archbishop of Canterbury, Dr. Layfield (a former confidant of her mother), and Francis Russell to accept the king's settlement. Dorset himself seemed unsure how to reconcile himself between his own courtly ambitions and his wife's prerogatives, and his treatment of her varied accordingly. Sometimes he was a blatant bully, other times he was supportive and loving. ${ }^{161}$

On 16 January 1617, Lady Anne received a letter from her husband, dictating that she was to come to court and appear before the king regarding her inheritance and the settlement. ${ }^{162}$ The next day, Dorset informed his wife that she should "resolve herself" to appear before James, but on the eighteenth, Lady Anne instead went first to the chambers of Queen Anna. It was there, according to Lady Anne's diary, that the queen spoke with her about the upcoming hearing:

Upon the $18^{\text {th }}$ being Saturday I went presently after dinner to the Queen to the Drawing Chamber where my lady Derby told the Queen how my business stood and that I was to go to the King so she promised me she would do all the good in it she could... The Queen gave me warning not to trust my matters absolutely to the King lest he should deceive me. ${ }^{163}$

Lady Anne and her husband then went before the king, who implored Lady Anne to renounce her claims to her inheritance and to leave the matter to his hands alone.

Predictably, Dorset readily agreed, but Lady Anne refused:

I beeseech'd his Majesty to pardon me for that I would never part from Westmorland while I lived upon any condition whatsoever. Sometimes he used fair means and persuasions and sometimes foul means but I was resolved before so as nothing would move me. From the King we went to the Queen's side. ${ }^{164}$

\footnotetext{
${ }^{161}$ Ibid., 62-65.

${ }^{162}$ Lady Anne Clifford, Isabella Barrios, Vita Sackville West, The Diary of the Lady Anne Clifford, 39.

163 Ibid., 39-40.

164 Ibid., 40.
} 
In the end, James was unable to force Lady Anne to back down and agree to the terms he had offered to her. The argument ended in a deadlock, and Lady Anne retained control of the Westmoreland estates, as well as those in Yorkshire. Lady Anne, with the influence, support and counsel of Anna, had won the day. ${ }^{165}$

Why had Anna taken Anne's side in this matter? As in the case of Beatrix Ruthven, Lady Anne Clifford was a noblewoman in Anna's court, but there is no reason why this should have caused Anna to defend definitively Lady Anne's interests against James. As with Arbella, Anna understood her husband's politics and patterns of court judgments well enough that she could predict that James would attempt either to cheat Lady Anne or, as it would turn out, to construct a settlement that was drastically out of her favor. These events gave Anna an opportunity to intervene on behalf of one of her courtiers in court politics, albeit indirectly. Again, as with Beatrix and Arbella, Anna genuinely liked Lady Anne, as it evident from the quote from Lady Anne's diary above that mentions how kindly Anna greeted her at their initial meeting, and Anna wanted to help Lady Anne because of this fondness for her lady-in-waiting. The fact that Anne had a longtime friendship with Anna's daughter Elizabeth would have also played in her favor. Whatever the case, Anna's influence is clearly seen in this instance, and it is an excellent example of her exercising her prerogative as a queen, albeit from behind the scenes, in order to go against James and his wishes.

\section{Anna's Understanding of Court Politics and Social Situations}

One of the key aspects of Anna's character that is sometimes overlooked, and one that shows to a remarkable degree her intelligence, was her ability to observe how

\footnotetext{
${ }^{165}$ Spence, Lady Anne Clifford, 65.
} 
courtiers acted within the greater scheme of court politics and make sound decisions regarding their motives and personalities. There were several high-profile examples of this attribute during Anna's time in England, and four of them will be discussed in the following section: Frederick Henry V, count of the Palatinate (who has already been briefly mentioned in the section on the Lady Elizabeth), Sir Robert Carr, the first Earl of Somerset, Sir George Villiers, the first Duke of Buckingham, and Lady Frances Howard, later the Countess of Somerset.

Anna was unhappy with the potential match of her daughter, Elizabeth, with Count Frederick Henry V from the start. There was always the problem of religion, of course: Anna had lobbied hard for Catholic matches for all of her children, including Elizabeth. Williams argues that Anna's unfavorable opinion of the Palatine was based on a combination of other factors, however: firstly, Frederick was not a true prince in his own right. Anna had been raised to take pride in her royal lineage and heritage, and she had tried to instill these same beliefs in her daughter. She did not see Frederick as being a worthy match for the daughter of a king and the sister of a future king. Secondly, Anna seems to have perceived certain negative character traits that her husband may not have seen: she saw that Frederick was not a particularly intelligent man, but one with great ambitions. ${ }^{166}$ This was a combination that Anna believed would lead to disaster down the line and, as it would turn out, she was correct. Despite her misgivings, however, Anna eventually relented and agreed to the match. She could see that Frederick had already won over her husband and daughter, and after the death of Henry (which had also left

\footnotetext{
${ }^{166}$ Williams, Anne of Denmark, 156.
} 
Elizabeth badly shaken), Anna seems to have lost the will to fight it. ${ }^{167}$ In a pair of letters written on 4 February and 11 February 1613, John Chamberlain made his own notes regarding Frederick Henry, as well as Anna's seeming acceptance of the match:

The worst is, methinks, he [Frederick Henry] is much too young and small-timbered to undertake such a task [the marriage to Elizabeth]... The Queen grows every day more favorable, and there is hope she will grace it [the wedding] with her presence. ${ }^{168}$

Anna was, after all, a highly pragmatic and practical woman. With her husband fully supporting the match (and the knowledge that Prince Henry had wholeheartedly supported the marriage as well), she saw that this was one battle that she could not win. Anna accepted that she would have to make the best of a situation of which she did not necessarily approve.

Elizabeth's marriage, which had been marked by the tragic death of her elder brother, was not to be the fairy tale that she had perhaps envisioned. Eventually, despite Anna's concerns that her daughter was marrying not only a Protestant, but a man well beneath her station as a princess, Elizabeth was crowned in Prague as the Queen of Bohemia on 7 November 1619 after the Protestant faction in the region invited her husband to take the throne. Frederick accepted the throne, but seems to have had very little understanding of the greater political situation in Bohemia. While the Protestant factions may have offered the throne to Frederick, the Holy Roman Emperor, Frederick II, believed the throne to be his by birthright, and he intended to take it. Consequently, the reign of Count Frederick V and Elizabeth Stuart was short-lived: Catholic armies quickly invaded the region and claimed it as their own. Because she ruled during those

\footnotetext{
${ }^{167}$ Ibid., 154-155.

${ }^{168}$ Chamberlain, Elizabeth McClure Thomson, ed., The Chamberlain Letters: A Selection of the Letters of John Chamberlain, 72-73.
} 
brief cold months in late 1619 and early 1620, Elizabeth would be known to history as The Winter Queen (although her reign would technically not end until 8 November 1620). Elizabeth's story had one final, slightly ironic twist that even her mother could not have predicted: it would be Elizabeth's heirs that, following the death of Queen Anne on 1 August 1714, would take the English throne and establish the Hanoverian line of succession. $^{169}$

Anna herself did not live to see her daughter become queen, or to witness the disastrous events that unfolded afterwards. She never saw her concerns about Frederick confirmed, but she had exhibited the foresight to predict how he would act under a given set of circumstances. While she never could have predicted that events in the German states would unfold the way they had, given her initial dislike of Frederick it is unlikely that she would have been surprised by his rapid rise and fall.

Anna's suspicions were similarly well-founded when it came to the first Earl of Somerset, Robert Carr. To better understand Anna's relationship with Carr and why it would become so contentious, it is necessary to first try and define what it meant to be a favorite at the court of James I. The position was fluid and ever-changing, subject to the whims and interests of James at any given moment. Consequently, it was common for one courtier to be favored for a period of years, only to be dropped seemingly without notice and replaced by a new favorite, often a younger rising star within the court. Such was the situation in which Carr found himself during his time at the Scottish court. Born sometime in 1587, Carr was the son of Thomas Carr, Laird of Ferniehurst, and Thomas' second wife, Janet Scott. Thomas Carr had been an outspoken and fierce proponent of

\footnotetext{
${ }^{169}$ Ibid., 141 and 148.
} 
Mary, Queen of Scots, and he transferred that loyalty to the deceased queen's son. ${ }^{170}$ Meanwhile, Janet Scott was responsible for sending Mary intelligence reports from Scotland during the latter's confinement in England. According to the English records, she also smuggled letters to James from the Earl of Lennox, who had been previously banished by the Scottish nobles who had kidnapped James during the first Ruthven raid. ${ }^{171}$ Robert Carr had been brought up in the royal household of Scotland and, in 1603, was made a page to the Treasurer of Scotland, Sir George Home. It was in this position that he first came to the attention of King James. When James went south to claim his new English kingdom, he took Carr along as well, and in the summer of 1604 the king named him a groom of the bedchamber. By December 1607, it was clear that the young, handsome, and athletic Carr was the new favorite at James's court. He was given an annual grant of $£ 600$ and knighted as a gentleman of the bedchamber. ${ }^{172}$

Although James clearly favored Carr, Anna was equally apparent in her dislike of him. ${ }^{173}$ It is unclear why Anna was antagonistic towards Carr, although one courtier noted that Carr himself accused Anna of jealousy regarding the latter's relationship with James, which would not have set well with the queen. ${ }^{174}$ In May and June 1611, the tense relations between the two (which had been growing increasingly more strained as Carr became closer to James and increasingly arrogant towards Anna) seem to have reached

\footnotetext{
${ }^{170}$ Alastair Bellamy, The Politics of Court Scandal in Early Modern England: News culture and the Overbury Affair, 1603-1660 (Cambridge: Cambridge University Press, 2002), 26.

${ }^{171}$ Ibid., 27.

${ }^{172}$ Ibid., 28-29.

${ }^{173}$ Ibid., 56.

${ }^{174}$ HMC Downshire, vol. III, p. 83 (Taverner to Trumbull: 1 June 1611); as cited in Bellamy, The Politics of Court Scandal, 47. Again, it is important not to read too much into this remark. While it is conceivable that James and Carr may have had an intimate relationship, it is equally possible (and perhaps even more probable) that Anna would have been jealous of the access that Carr had to James and the influence that he was able to exert over the king.
} 
its high point. Anna was displeased that Carr was elbowing in on her own patronage at court, especially since it was one of the few areas where she had real influence and power, and she liked even less his close friendship with Thomas Overbury, who was probably guiding Carr's decisions and actions at court from behind the scenes. Carr by himself was relatively harmless (or so Anna initially believed), but when he was paired with the brilliant political mind of Thomas Overbury he was a potential threat not only to Anna's royal prerogative, but to the future of her son Henry as well. As Overbury lobbied from behind the scenes to transfer increasing amounts of power to Carr, Anna became more and more distrustful of both men. Finally, Anna accused Overbury and Carr of laughing (allegedly) at her from the garden, and demanded that James punish them, which he reluctantly did. Overbury was banished from the court for a short time, and Carr was required to apologize to Anna. ${ }^{175}$ Since Anna was often in tune with the atmosphere of court politics, she could see that Overbury was the one pulling all the strings behind Carr. Given her talent for understanding and, when possible, manipulating court politics, Anna could hardly have been displeased with Overbury's banishment. While she intended to have Carr himself removed from court, removing Overbury was certainly a step in the right direction. Without Overbury, Carr would begin getting himself into trouble. Carr grew so arrogant that even after Overbury returned from a brief exile, Carr refused his former mentor's advice and dug himself into an even deeper hole that would lead to his own removal from court.

In Overbury's absence, Carr's life became intertwined with that of another courtier whom Anna would never fully trust and against whom she would act. This time,

\footnotetext{
${ }^{175}$ Bellamy, The Politics of Court Scandal, 47.
} 
it was not a man, but a woman who was the subject of Anna's distrust: Frances Howard, Countess of Essex (and later the Lady of Somerset). Frances had initially been married to the Earl of Essex (in 1606 when they were thirteen and fourteen years old, respectively). Essex had then been sent abroad almost immediately to further his education, while Lady Frances remained at the English court to continue hers. When she met Robert Carr at the court of King James (probably sometime in 1612), the pair began an affair that would prove disastrous for both of them. By the time Essex returned from the continent, he found a wife that was not even remotely interested in him or their marriage. In fact, Frances made a significant effort to repel all of the advances made by her husband through a combination of drugs, ${ }^{176}$ which were intended to make him impotent, and outright hostile behavior. ${ }^{177}$ Frances eventually successfully petitioned James for a nullification of her marriage with Essex, and the marriage was officially annulled on 25 September 1613 (despite the fact that James himself had arranged the Essex marriage). She was hoping to marry Carr. A marriage with Carr, the king's favorite, would move Frances (and by extension, the entire Howard clan) closer to the king. ${ }^{178}$

Despite the misgivings of Anna and the whisperings at court following the death of Thomas Overbury, which will be discussed in more detail below, James had been enthusiastic about the wedding between his current favorite and Frances Howard. Anna was reluctant to attend the ceremony, but James was able to persuade her to attend by handing over Greenwich Palace to her. ${ }^{179}$ That Anna accepted this gift should not be interpreted as an act of weakness or pettiness; rather, Anna would have understood that

\footnotetext{
${ }^{176}$ Green, ed., Calendar, 173.

${ }_{177}$ Nichols, Progresses, Vol. III, 80.

${ }^{178}$ Green, Calendar, 183.

${ }^{179}$ Ibid., 212.
} 
she would be required to attend the wedding one way or another, and if she could gain control of Greenwich Palace during the negotiations, all the better for her. ${ }^{180}$ After the wedding on 26 December 1613, however, Carr made two crucial errors that would lead him even farther down the path of his own undoing: first, he became more openly disrespectful and antagonistic towards Anna than he had been previously. Second, and even more seriously, Carr began neglecting James in favor of his new wife. This slowly eroded the credit he had been building up with the king. Meanwhile, the Protestant lords Pembroke, Hertford, and Bedford decided that Carr had to be removed from power before he was able to do any more damage within the government than he already had. ${ }^{181}$ Carr, despite the significant amount of time he spent at court and at the side of King James, does not seem to have had any sort of grasp on the machinations of court politics or the intentions of his opponents. His continued arrogance in the face of such opposition illustrates this. Given his past behavior, had Carr still been under the restraining hand of Overbury, he certainly would have comported himself with more decorum and respect.

As it was, Carr himself had contributed (directly or indirectly) to Overbury's demise on 28 September 1613 , and he was about to reap the consequences. ${ }^{182}$

The lords decided that the only way to remove Carr from power was to provide James with a new favorite. They selected the handsome twenty-two year old George Villiers as their candidate. Villiers, however, lacked the type of powerhouse support that

\footnotetext{
${ }^{180}$ Ibid., 205.

${ }^{181}$ Williams, Anne of Denmark, 166-168. Following his marriage, Carr became openly disrespectful of Anna and many of James's other courtiers. What made matters worse was that Lady Frances proved to be a very demanding wife, and often kept Carr away from James. When he did make appearances at court, he was often temperamental and prone to tantrums. Furthermore, by marrying into the Howard clan, Carr had also taken on all of their enemies as well. Since he was now part of a Catholic faction and no longer considered "neutral," Carr was a potential danger to the Protestant faction at court.

${ }^{182}$ Green, Calendar, 200, 316-317.
} 
Carr had found with the Howards. In an attempt to remedy this last problem, the Earl of Pembroke approached Anna and asked her to grant her support to Villiers. Although Anna had no love for Carr, she was hesitant to involve herself in what she believed would be simply the next in a long line of schemes and maneuverings for the privilege of being James's new favorite. ${ }^{183}$ Next George Abbot, the Archbishop of Canterbury, pleaded with Anna to assist with the overthrow of Carr. Anna was still reluctant, and her reply to Abbot illustrates perfectly the keen understanding she had of court politics and the actions of courtiers. She argued that if they replaced Carr with Villiers, those that put Villiers in power would be the first people that he would turn on should he achieve high status with the king. Anna, based on past experience with the king's other favorites, predicted that her husband would teach Villiers to shun Anna and the others just as he had presumably taught Carr. She also suspected, correctly, that Villiers would soon come to believe that he owed his position to no one but himself and the king. ${ }^{184}$ In short, Anna already knew that if the Protestant lords replaced one favorite, Carr, with another, Villiers, they would only be exchanging one set of problems for a different set. Ultimately, however, Anna decided that something had to be done to remove Carr from power, and she agreed to put forth Villiers' candidacy for knighthood and for a position as a gentleman of the king's bedchamber, despite her misgivings. ${ }^{185}$

What convinced Anna to change her mind regarding Villiers? Anna was not known to back down to pressure, not even from her husband (as was evidenced both in her fight for the custody of Henry and in her defense of Beatrix Ruthven), and so this

\footnotetext{
${ }^{183}$ Willson, King James VI and I, 352.

${ }^{184}$ Hugh Ross Williamson, George Villiers, First Duke of Buckingham, Study for a Biography (London: Duckworth, 1940), 39.

185 Nichols, Progresses, 80.
} 
does not explain why she eventually would have acquiesced to the pleas of Abbot and the other nobles who were promoting Villiers. The best explanation for Anna's agreement is that Carr's behavior had really gotten out of hand. Anna could already see that Villiers was unlikely to be much better than Carr, but evidently his advancement was preferable to allowing Carr to remain in power. This is another example of Anna's pragmatism: her situation was bad under Carr, and it was unlikely to be any better under Villiers, but at least there was a possibility of something better if Carr was replaced. In the worst case scenario, the status quo would remain the same for awhile. She had very little to lose by replacing one court favorite with another.

Villiers slowly but surely became the new favorite. As Villiers' star rose, that of Carr dimmed. By the summer of 1615, Carr finally realized that he was losing ground. He began lobbying for a comprehensive pardon that would protect him from any charges, real or imagined, that his enemies might bring against him. Unfortunately for Carr, everybody around him could see that he was no longer the court darling, and therefore no longer carried the same weight or influence. ${ }^{186}$ Nobody would issue a seal for the pardon, and in mid-October 1615 Carr and his wife, Lady Frances, were placed under house arrest on the suspicion of poisoning Thomas Overbury. ${ }^{187}$ Frances, perhaps realizing the severity of her situation, finally attempted to curry favor with Queen Anna by naming her daughter, who was born on 9 December 1615, after the queen. Anna, who had never thought much of Frances, her morals, or her actions, was not moved. ${ }^{188}$

\footnotetext{
${ }^{186}$ Akrigg, Jacobean Pageant, 188-189.

${ }^{187}$ Green, Calendar, 316.

${ }^{188}$ Williams, Anne of Denmark, 175.
} 
One question remains regarding Carr: Why were he and his wife suspected of poisoning Overbury? Possibly due to a previous falling out between Carr and Overbury, a falling out that had been sparked by his relationship with Lady Frances. ${ }^{189}$ It was not long after the beginning of the relationship between Carr and Lady Frances that rumors of poisoning and a plot by Carr and Lady Frances had begun to circulate at court. It is impossible to understand, now, what happened to Overbury, but the poisoning theory is not impossible. Frances Howard would, during her trial, admit her guilt in the affair. ${ }^{190}$ The death of Overbury was the first in a series of events that would bring about the downfall of both Robert Carr and Frances Howard, and would vindicate Queen Anna and her character assessments of Carr, Howard, and George Villiers, the future Duke of Buckingham. Both Carr and Frances went on trial for the murder of Overbury, along with several other alleged co-conspirators. Carr flatly refused to confess to any of the charges leveled against him, claiming that the letters introduced as evidence against him must have been counterfeits. ${ }^{191}$ Lady Frances, on the other hand, chose to make a full confession, presenting herself all in black and adopting a demure and modest demeanor, a demeanor with which spectator John Chamberlain was unimpressed:

His Lady was arraigned yesterday and made shorter work by confessing the indictment, so that all was done and we at home before noon. She won pity by her sober demeanor, which in my opinion was more curious and confident than was fit for a lady in such distress; yet she shed, or made show of, some few tears diverse times... The general opinion is that she

\footnotetext{
${ }^{189}$ Green, Calendar, 315.

${ }^{190}$ Chamberlain, The Chamberlain Letters, 120. This admission on Frances's part does not in any way confirm or deny the poisoning theory. There are any number of reasons why she may have given a true or false confession, and so it would be imprudent to take her at her word, or the word of the investigators. At this juncture in history, the truth was irrelevant: only the confessions, and the consequences thereof, mattered.

${ }^{191}$ Green, Calendar, 368.
} 
shall not die, and many good words were given to put her in hope of the King's mercy. ${ }^{192}$

The pair was found guilty and sentenced to death; ${ }^{193}$ however, it came as no surprise to anybody when the sentences were commuted and Carr and his wife were moved to the Tower of London. ${ }^{194}$

In the meantime, Villiers' ascension to power was complete. In April 1616 he was created Viscount Villiers ${ }^{195}$ and then, in January 1617, he was named the Earl of Buckingham. ${ }^{196}$ If it was possible, Villiers had an even greater hold on James's attention than Carr had enjoyed. True to Anna's fears, Villiers quickly forgot those friends who had helped him into power. As noted previously, when Anna wrote to him asking him to intervene with James on behalf of Walter Raleigh, he ignored her pleas. When writing his memoirs in later years, George Abbot, Anna's friend and the Archbishop of Canterbury, would recall the rise of Villiers and remark, "Noble Queen, how like a prophetess or oracle did you speak."197

Anna had assessed the character and ambitions of Henry Frederick, Robert Carr, Frances Howard, and George Villiers, and she had found them all wanting. In order to have made these assessments, Anna had to have had a reasonable understanding of what was happening at court, and she predicted (with a fair degree of foresight) the long-term consequences of the actions surrounding these courtiers. Anna had also displayed remarkable intelligence in her ability to make these assessments and weigh the relative

\footnotetext{
192 Chamberlain, The Chamberlain Letters, 120.

${ }^{193}$ Green, Calendar, 372.

${ }^{194}$ Ibid., 387.

195 Ibid., 363.

196 Ibid., 422.

${ }^{197}$ Nichols, ed., Progresses, 80.
} 
risks and benefits of her potential actions regarding her favorites and friends. That Anna was able to take calculated risks when it came to defending her favorites, and that her husband never directly chastised her for her advocacy, indicates that she also understood how to manipulate her own position as the wife of a king (as opposed to a queen regnant) and how far she could reasonably press an issue. Anna would never have the power of a queen regnant, but she made the effort to exercise what agency and autonomy she could given her circumstances, rather than settling for a life of inaction. When Anna believed in a cause or a person, she made it known, and she made an effort to act on that belief. Another manifestation of Anna's intelligence was articulated in her production of, and participation in, a theatrical art form that reached its pinnacle under her reign: the court masque, which the next chapter of this thesis will explore. 
Chapter Four: Anna's Masquing Career and the Development of a

Female Identity on the Court Stage

The relationship between the English court and the world of theater was a

complicated one, at best. When James took the English throne in 1603, William

Shakespeare was at the height of his career, and theater was becoming more acceptable as a diversion for the upper classes. A career in acting, while still only slightly more respectable than a career as a prostitute, was becoming more lucrative as monarchs began hiring entire troupes of actors to serve their households. As the nobility gained a greater appreciation for the art, they also sought ways in which to mimic it at court. The court masque was not quite a play; it was a type of theatrical performance that was not only acceptable for nobles to view, but in which it was also acceptable for them to participate. In a court masque, a series of dances would be performed by a set number of courtiers in elaborate costumes designed in accordance with the theme and plot of the masque. The plot itself was developed by the writer, and reads more like lines of poetry rather than like a traditional play. These lines were spoken at the beginning and end of the masque, and then interspersed at appropriate intervals in between the dances and songs. The dances were choreographed to represent and enhance the text of the play, and were largely the focus of the masque. ${ }^{198}$ In order to appreciate the court masque and where it

\footnotetext{
${ }^{198}$ Graham Parry, "Entertainments at Court," in A New History of Early English Drama, eds. John D. Cox and David Scott Kastan (New York: Columbia University Press, 1997), 195-196. A court masque would have had brief speaking or singing roles, usually played by professional actors, but the focus would have been the dances. An even number of dancers (initially eight men, but Anna would later increase this number to twelve and then sixteen women) would perform a series of carefully choreographed dances and measures. While the first dances would be made by the masquers alone, the final number would involve a "taking-out," in which the masquers selected dancing partners from the audience. This invitation to dance could be used as a powerful way to make a political or social statement. Masques were known for their elaborate costumes and scenery, and were often used at court celebrations.
} 
stood in relation to the theatrical arts as a whole, it is first necessary to sketch out a brief picture of Early Modern English theater.

The earliest form of theatrical entertainment during the Early Modern period was the court pageant, made popular during the reigns of Henry VII and Henry VIII. ${ }^{199}$ These pageants were, more than any other form of theater, the precursor to the court masque. Initially inspired by the Burgundian pageants of the fifteenth century, the English royal pageants consisted of a series of tableaux and sporting events arranged in a sort of parade. ${ }^{200}$ Typical athletic events featured during a pageant included tilts, barriers, and passages-at-arms, while each tableau was an elaborate work of art and machinery, and usually featured an allegorical theme or a scene from classical mythology. For example, at the wedding of Princess Katherine of Aragon and Prince Arthur, a display was created that featured two mounts: one was green and laden with flowers, while the other was sun burnt and decorated with fine jewels. The two mounts were joined by a golden chain, and the entire scene was meant to represent the friendly union of England and Spain. Later that evening, a naval "battle" between a band of pirates and a cadre of noble knights was played out in the great hall, complete with a fully outfitted ship. During the Twelfth Night entertainments of 1512, King Henry VIII introduced a new theatrical element that he had picked up from the Italian court: he and eleven of his companions entered the hall

\footnotetext{
${ }^{199}$ Hero Chalmers, “'Break Up the Court': Power, Female Performance and Courtly Ceremony in Henry VIII," Shakespeare 7, no. 3, (2011): 257-268; Matthew Woodcock, “"Their Eyes More Attentive to the Show': Spectacle, Tragedy and the Structure of All Is True (Henry VIII)," Shakespeare 7, no. 1 (2011): 115.

${ }^{200}$ Martin Butler, The Stuart Court Masque and Political Culture (Cambridge: Cambridge University Press, 2008), 1.
} 
"disguised" in masks. It was a relatively minor change from the ordinary order of things, and yet it would have a profound effect on the evolution of court theater. ${ }^{201}$

Although the pageant form declined towards the end of Henry VIII's reign and fell out of favor during the brief reigns of Edward VI and Mary I, it came back into fashion under Elizabeth I. ${ }^{202}$ Elizabeth also favored stage plays, and the last years of her reign saw an increase in their production at court, presumably at Whitehall. The use of masks also made a comeback under Elizabeth, but this time the revelers wearing masks also participated in a pre-arranged dance or series of dances, and would then draw other guests into the dance. This was the next evolution in what would eventually become the court masque as it was known during the reign of James and Anna. James never participated in a masque himself, although he produced several and he certainly knew how to use them to his advantage. According to Martin Butler in his essay titled "Courtly Negotiations," the masques that James had a hand in producing were more of a conversation than a performance:

James, though, never danced, and his masques must have been more like acts of lobbying, in which groups of aspiring courtiers conducted a symbolic conversation with their monarch, designed to persuade him of their worth or to convince the court as a whole of their own importance in larger schemes. ${ }^{203}$

Anna, on the other hand, took a much more active role in the court masque and developed it in ways that James did not. She was still in frequent contact with her brother, King Christian IV of Denmark, and had a connection to the wider world of

\footnotetext{
${ }^{201}$ Parry, "Entertainments at Court" in A New History of Early English Drama, eds. John D. Cox and David Scott Kastan, 195-196.

${ }^{202}$ Smuts, Court Culture, 141-142. Smuts suggests that the reason for the decline of the pageant form during the reigns of Edward and Mary can be linked to Protestant "attacks" on religious art and ceremony, from which the pageants had initially sprung.

${ }^{203}$ Martin Butler, "Courtly Negotiations," in A New History of Early English Drama, eds. Cox and Kastan, 28.
} 
European court entertainments. When she arrived in England, she brought with her a taste for the arts and, more specifically, the court masque. From her brother's court she hired John Dowland, a composer, and Inigo Jones, perhaps the most famous set designer and architect of the early modern era. ${ }^{204}$ The masque itself was relatively new to England, although the form had been popular in Italy for some time. Anna, with her desire to participate physically in a theatrical form with her noblewomen, claimed the masque form for herself and developed it in such a way as to make it uniquely her own. ${ }^{205}$

\section{Masques Given For Anna}

Anna was first introduced to the masque during her progress south from Scotland to England in June 1603. When her entourage reached the house of Lord Spencer at Althorp on 25 June, they were treated to a performance of Ben Jonson's Masque of the Faeries ${ }^{206}$ This was also the first time that Anna witnessed the work of Jonson, who would benefit from Anna's patronage during her time in England.

The Masque of the Faeries, also known simply as The Satyr or The Entertainment at Althorp, was not Jonson's first work for the new royal family: he had already presented two entertainments for King James upon his entry into England. Faeries, which had been commissioned by Lord Spencer for the queen's visit, was clearly an attempt by Jonson to please, if not outright ingratiate himself with, Anna. The masque centers around a satyr and a host of faerie folk who have gathered to greet the new queen and the young prince

\footnotetext{
${ }^{204}$ Wade, "Anna of Denmark and Her Royal Sisters," in Women and Culture at the Courts of the Stuart Queens, ed. McManus, 61-62.

${ }^{205}$ Parry, "Entertainments at Court," in A New History of Early English Drama, eds. Cox and Kastan, 199200.

${ }^{206}$ Lady Anne Clifford, Isabella Barrios, Vita Sackville West, The Diary of the Lady Anne Clifford, 6.
} 
Henry. In the production notes, Jonson describes how the masque was to begin as Queen

Anna and her party arrived at the site of the masque:

The Invention was, to have a Satyr lodged in a little Spinet, by which Her Majesty, and the Prince were to come, who (at the report of certain Cornets that were devided in several places of the Park, to signifie her Approach) advanced his head above the top of the wood, wondring, and (with his Pipe in his hand) began as followeth. ${ }^{207}$

The masque then went on to describe exultations made by the satyr and the faeries, although the bulk of the entertainment was expressed through music and dance. In one song, the virtues of Anna are enumerated, particularly her bringing with her a son. That son, Prince Henry, was “a Kingdom's happiness," and Anna herself was described as being the personification of Oriana, the successor of Diana (Elizabeth). The production notes go on to describe Lord Spencer's son being fetched from the woods costumed as a huntsman at the end of the first night of the entertainment. At this point, hunting horns sounded and two young bucks were released. The staged hunt went exactly according to plan, and the two deer were successfully killed in front of Anna. The next day was Sunday, and so the queen was given a brief respite from travel and revelries, but the entertainment was intended to continue on Monday evening. As Jonson noted in his write up of the events, however, this was not to be:

\footnotetext{
${ }^{207}$ Ben Jonson, Clark Holloway, ed., A Particular Entertainment of the Queen and Prince Their Highness at Althorpe, 1603 (London: William Stansby, 1616), last date updated: 2003,

$<$ http://hollowaypages.com/jonson1692queen.htm>. I owe a great debt of gratitude to Mr. Clark Holloway, who transcribed in their complete form all the works of the writer Ben Jonson. Although Mr. Holloway is not affiliated with any academic organization, his transcriptions have been cross referenced with other available excerpts of Jonson's work, which can be found at $<$ http://ia700508.us.archive.org/10/items/completeplayswi01jonsuoft/completeplayswi01jonsuoft.pdf $>$. A complete cross referencing was also done with the complete texts of Jonson's Masque of Blacknesse and his Masque of Beautie, according to an original copy of those texts. Mr. Holloway's transcriptions have been found to be carefully and faithfully transcribed, complete with Jonson's own extensive production notes in the margins.
} 
Where there was a Speech suddenly thought on, to induce a Morris of the Clowns thereabout, who most officiously presented themselves, but by reason of the throng of the Country that came in, their Speaker could not be heard, who was in the person of NoBody... There was also another parting Speech, which was to have been presented in the person of a Youth, and accompanied with divers Gentlemens younger Sons of the country: but by reason of the multitudinous press, was also hindred. ${ }^{208}$

Unfortunately, Jonson's notes do not indicate how Anna reacted to her first masque, but it can be surmised by the events that unfolded later that she was quite pleased. After all, Ben Jonson would be one of the writers favored by Anna (though certainly not the only one) when she commissioned her masques. Of course, Lucy Countess of Bedford was also a noted patron of Jonson, and her favor could have only enhanced Jonson's worth in Anna's eyes. ${ }^{209}$ Anna, however, was not known simply to follow the will of her friends and courtiers, nor was she known to patronize artists that lacked talent. Jonson had crafted his words carefully, coming across as respectful and appropriately awed while not appearing obsequious. His portrayal of Anna as the successor of Elizabeth, rather than as her replacement or as an inferior substitution was brilliant, since it employed the idea of tradition and continuity that spoke to the English consciousness. Also, the fact that Anna took to the court masque so enthusiastically would indicate that she had developed an appreciation for the art, and Ben Jonson was probably due at least partial credit for this.

This was not the last masque entertainment given for Anna, nor was it the only form of entertainment presented to her during her time as queen. One notable example of a non-masque entertainment was given in June 1613 by the mayor, Abell Kitchin, the sheriffs, Christopher Cary and John Barker, and the aldermen of the city of Bristol. The masque was accompanied by speeches, gifts, and "water-combats" (mock naval battles at

\footnotetext{
${ }^{208}$ Ibid.

${ }^{209}$ Williams, Anne of Denmark, 79.
} 
sea). ${ }^{210}$ The surviving record details a lengthy poem written by one Robert Naille that was dedicated to Anna and her health. ${ }^{211}$ One of the other surviving records of an entertainment given specifically for Anna does in fact detail a masque that was given in 1613. This masque, written by Thomas Campion, was presented to Anna during a royal progress that she made to Bath, where she was going to take the waters to treat her severe gout. It was sponsored by Lord Knowles at his estate at Cawsome House. Like The Masque of the Faeries, Campion's untitled masque spoke of the queen in the most flattering of terms. Campion's story dealt with questions about society and culture, and the opening figure who addressed the audience (and more specifically, the queen) was the character of the "Cynick." 212

When the queen and her party approached the gardens where the masque was to take place, a disguised traveler emerged from amongst her own party and engaged the Cynick in conversation. As the Cynick is drawn into conversation with The Traveler, and as he hears the praises of Queen Anna and her graces, he becomes more and more civilized and willing to enter society:

Sure I am, it hath stir'd [u]p strange thoughts in me, ne[v]er knew I the difference betweene Wine and Water before. Bacchus hath opened mine eyes, I now see bra[v]erie and I admire it, beautie \& adore it. I find my Armes naked, my discourse rude, but my heart soft as Waxe, ready to melt

\footnotetext{
${ }^{210}$ These particular entertainments are reminiscent of those given for and by Queen Elizabeth during her reign and her progresses through England, which were marked with elaborate stageworks and mock land and sea battles. For more information about these entertainments, see: Records of Early English Drama. "Elizabeth Tudor (1533-1602/3)," accessed 28 Apr. 2012, < http://link.library.utoronto.ca/reed/eventhits.cfm?PeopleListID=533>.

${ }^{211}$ Robert Naille, A Relation of the Royall, Magnificent, and Sumptuous Entertainement Giuen to the High, and Mighty Princesse, Queene Anne, at the Renowned Citie of Bristoll, by the mayor, sherrifes, and aldermen thereof; in the moneth of Iune last past 1613 (London: Printed for John Budge, 1613).

${ }^{212}$ Thomas Campion, A relation of the late royall entertainment giuen by the Right Honorable the Lord Knovvles, at Cawsome-House neere Redding: to our most gracious queene, Queene Anne, in her progresse toward the Bathe (London: William Stansby, 1613).
} 
with the least beame of a faire eye; which (till this time) was as [u]ntractable as Iron. ${ }^{213}$

In this scene, Anna is not only being associated with the feminine virtues of grace and beauty, but she is also being presented as a civilizing force to the uncivilized and antisocial Cynick. Although this masque took place ten years after Anna had first arrived in England, and about twenty-two years after Anna had arrived in Scotland as queen, the idea of Anna as a civilizing force echoes her early years at the court of King James, when she was reputed to be a proper and well-mannered antidote to the boisterous and unkempt atmosphere that was prevalent under her husband's watch. While Campion almost certainly was not trying to associate James with the Cynick, ${ }^{214}$ it seems that on some level he was giving Anna credit for her gentility and good breeding.

Unlike the masque given at Althorp, Campion's production notes indicate that the audience (in this case, Anna and her train) were not intended to remain in one place during the performance, but were rather escorted through a series of stations at which different elements of the masque would take place. In fact, Campion at one point expresses concern that it had rained earlier in the day, and the ground would be damp beneath the queen's feet. He had rolls of cloth unrolled along the path that the party was intended to follow so as to keep their feet and attire dry. ${ }^{215}$ This particular theatrical device, that of having the audience travel along a set path to witness the events of the performance, is of great interest in this masque. As Anna and her train moved through the various stages of the masque, the performers spoke of how her benevolent influence and

\footnotetext{
213 Ibid.

${ }^{214}$ James was a great patron of Campion's, certainly more so than Anna, who favored Ben Jonson and Samuel Daniel. Campion would compose several masques for James, including the famous The Lords Masque that was performed at the wedding of the Princess Elizabeth to Frederick Henry V.

${ }^{215}$ Campion, A relation of the late royall entertainment giuen by the Right Honorable the Lord Knovvles.
} 
graces were spread throughout the realm. The gardener character described how sweet the air is when Anna is present, and how the flowers bloom more magnificently.

Therefore, Anna is responsible for the blessings and good fortune of the land. The following verse is an example of this:

Dance now and sing the [j]oy, and love we owe:

Let chearfull voices and glad gestures showe, The Queene of grace is shee whom we receive Honour and state are her guides Her presence they can never leave Then in a stately sil[v]an forme salute Her ever flowing grace Fill all the Woods with Ecchoed welcomes, And strew with flowers this place: Let e[v]'ry bow and plant fresh blossomes yeeld, And all the aire refine.

Let Pleasure strive to please our goddesse, For shee is all di[v]ine.

Yet once againe, let us our measures mo[v]e, And with sweet notes record our [j]oyfull love. An object more di[v]ine none e[v]er had. Beautie, and hea[v]'n-borne worth, Mixt in perfection ne[v]er fade.

Then with a dance triumphant let $[\mathrm{u}] \mathrm{s}$ sing Her high ad[v]anced praise, And e[v]'n to hea[v]'n our gladsome welcomes, With wings of musick raise, Welcome, O welcome, e[v]er-honoured Queene, To this now blessed place, That gro[v]e, that bowre, that house is happy Which you vouchsafe to grace. ${ }^{216}$

Again, there is the imagery of grace and beauty that was so often associated with Anna.

Anna's Masques

In her book titled Women on the Renaissance Stage: Anna of Denmark and Female Masquing in the Stuart Court (1590-1619), Clare McManus suggests that,

${ }^{216}$ Ibid. 
although Anna undoubtedly contributed greatly to the acceptance of the court masque as a royal art form, it was instead Ben Jonson who was primarily responsible for developing a female presence on the court stage. ${ }^{217}$ While McManus goes on to make some valid observations and interesting analyses regarding Anna and the court masque, this initial assumption is almost certainly false. In fact, McManus contradicts herself a page later, stating that,

In particular the tensions caused by Anna's active agency in commissioning and influencing this performance (Blackness) reveal much about her masquing career and the nature of female performance and cultural agency in the Jacobean court. ${ }^{218}$

While Ben Jonson certainly deserves due credit for penning some of Anna's masques, it seems ill-advised to credit him with the development of a female presence on the masquing stage. Rather, Anna was probably primarily responsible for this development at this time.

First, while Jonson was only one of the writers that Anna employed to author her masques, he did write four of the six masques in which Anna personally performed. Consequently, it would seem reasonable to assume that he would write masques commissioned by Anna with an eye towards pleasing her, and therefore it would be Anna's desires that would manifest themselves in Jonson's work. Anna apparently wanted not only to participate actively in the masque, but to allow her ladies to as well. Had Anna been indifferent or opposed to women on the masquing stage, it is unlikely that Jonson would have made much of an effort to create masques that featured women

\footnotetext{
${ }^{217}$ Clare McManus, Women on the Renaissance Stage, 2.

218 Ibid., 3.
} 
almost exclusively. ${ }^{219}$ Second, as will be expounded upon later in the examination of The Masque of Queens, Anna was adamant when it came to the roles that women would play in her masques: usually preferring goddesses associated with specific virtues, or warrior queens. Anna was always very involved with the production aspects of her masque, even down to the character development. Given that Anna was rarely known to back down without a fight, Jonson probably would not have been able to produce a character that Anna had not approved or even helped to create.

Bearing this in mind, each of the six masques in which Anna participated directly will be examined. By looking at the type of role Anna took on for herself in each of these performances, as well as examining the text of the masques themselves, it is possible to learn a great deal about Anna and how she exercised her intelligence when it came to expressing herself on the masquing stage. The first masque in which Anna ever performed personally was The Vision of Twelve Goddesses by Samuel Daniel (who had, incidentally, also been a tutor to the Lady Anne Clifford). The masque, which debuted on 8 January 1604 in the great hall at Hampton Court, was performed by Anna and eleven of her ladies. Each lady took on the role of a Greek goddess, with Anna herself taking on the character of Pallas Athena, the goddess of (amongst other things) wisdom, courage, and civilization. $^{220}$

\footnotetext{
${ }^{219}$ Jonson's works for other patrons featured either male masquers exclusively, or an equal combination of male and female masquers, thus creating a gender balance.

${ }^{220}$ Samuel Daniel, Ernest Law, ed., The Vision of the Twelve Goddesses: A Royal Masque (London: Bernard Quaritch, 1880), 45.The other participants and their respective roles are as follows: Lady Suffolk as Juno, Lady Rich as Venus, Lady Hertford as Diana, Lady Bedford as Vesta, Lady Derby as Prosperine, Lady Hatton as Marcaria, Lady Nottingham as Concordia, Lady Walsingham as Astræa, Lady (Susan) Vere as Flora, Lady Hastings as Ceres, and Lady (Elizabeth) Howard as Tethys. The speaking roles of Somnus, Iris, Night, The Graces, and The Sybil were most likely played by professional actors, since they required speaking and singing.
} 
Anna herself selected the roles that she would portray in the masques in which she performed. In his production notes for Goddesses, Samuel Daniel writes that,

Pallas (which was the person her ma[j]esty chose to represent) was attyred in a blew mantle, with a sil[v]er imbrodery of all weapons and engines of war, with a helmet-dressing on her head, and presents a Launce and Target. $^{221}$

By assuming the role of a Greek goddess, Anna was appealing to the love of humanist scholarship that had once been a mainstay in England (although, as previously discussed, it had since gone out of fashion for women), which extolled the virtues of Greek and Roman learning and culture. Anna's court was well-known for its neo-Platonism, which would have celebrated the same Greek and Roman mythology, and so it makes sense that she would have referenced this tradition. Not only did Anna pick a Greek goddess, but she selected the one who was associated with powerful and intellectual pursuits.

After the initial exposition spoken by the characters of Night, Somnus, and the Sybil, the twelve goddesses descended a mountain via a staircase in rows of three and presented their "offerings" to the Temple of Peace. Then, a series of dances was performed, consisting of

Di[v]ers straines, fram'd [u]nto motions circular, square, triangular, [w]ith other proportions exceedingly rare and full of variety; the Godesses made a pause, casting themsel[v]es into a circle, whilst the Graces againe sang to the Musick of the Temple, and prepared to take out the Lords to dance. $^{222}$

After the taking out and the closing dances, the Goddesses once again ascended the staircase, and the masque concluded.

\footnotetext{
${ }^{221}$ Ibid., 59.

${ }^{222}$ Samuel Daniel, Ernest Law, ed., The Vision of the Twelve Goddesses, 63.
} 
This was the first masque that Anna commissioned and produced herself, and so the fact that there is little in it that is shocking or controversial is not surprising. The symbolism inherent in the Temple of Peace theme is obvious: James had made a point to present himself as a peaceful king when he came to England. James's ascension to the English throne had been marked by the end of the Irish rebellion and an increase in friendly relations between England and Spain. When Daniel wrote Goddesses, England was in a rare time of peace. Therefore, the temple is representative of James and his pacifist policies, ${ }^{223}$ and although Anna adopted the character of a warrior goddess, her character is seen respectfully making an "offering" to the temple and, by extension, to her husband. Yet there is something simmering underneath this outward deference, something that can be gleaned from reading the description that The Sybil uses for Anna's character:

Next war-like Pallas, in her Helmet drest With Lance of [w]inning, Target of Defence: In [w]hom both Wit and Courage are exprest, To get with glory, hold [w]ith Pro[v]idence. ${ }^{224}$

It is a powerful description, and one that, from what can be reasonably determined about Anna's personality, exemplifies her own qualities as well as those of Pallas Athena. Of course, this raises a chicken or the egg question: did Anna choose this role based on this description, or did Anna influence the way Daniel wrote the character? In either case, it is clear that these were qualities that Anna prized. It is possible that Daniel was writing the character to flatter his patroness, but if this is the case then it can be safely assumed that these qualities, those of wit, courage, and bravery, were ones with

\footnotetext{
${ }^{223}$ David M. Bevington and Peter Holbrook, The Politics of the Stuart Court Masque (Cambridge: Cambridge University Press, 1998), 72-73.

${ }^{224}$ Daniel, Goddesses, 68.
} 
which Anna herself wanted to be associated- qualities Daniel would have known to be consistent with her public persona. The same deduction can be made if Anna was directly involved with the development of her character: she would have been sure to highlight attributes that she wanted the audience to associate with her persona. In this first masque, Anna is not challenging the traditional order of things or even making a controversial religious or political statement, but is using the masque as a platform to create a public identity for herself.

The process of creating a public identity would have been a difficult process for Anna. Although she was well-loved by the common people, this would have counted for little or nothing at court. In order to have any voice or influence amongst the noble and gentle classes, it was crucial that Anna find some way to present her self-image that would fall within the confines of acceptable court behavior while also getting the message across. The court masque was uniquely well-suited for this purpose. It was an art form that was limited to the upper classes, which was exactly the audience Anna would have been attempting to influence. Also, because the masque was as much an artistic expression as it was a political display, it was possible to insert layers of symbolism, metaphor, and suggestion that would have been more difficult (or even impossible) to use in public statements or even in letters or official documents.

Within the context of the masque Anna was able to present herself as a powerful woman: a woman whose capabilities rivaled those of her husband, and one who was willing to wage the wars that James was not willing to wage. James may well have been presented as the bringer of peace, but even as Anna's character made an offering to him in this guise, Anna herself was still setting herself apart by identifying with Pallas 
Athena. Anna could just as easily have taken on the role of Juno, the mother Goddess, or Venus, the Goddess of beauty, or even Tethys, the river Goddess and wife of Oceanus. ${ }^{225}$ All of these roles included characteristics that could have described Anna (such as beauty) or that could possibly have appealed to her (such as motherhood). So why did she ultimately portray Pallas Athena? Beauty was certainly not a negative trait, but it was one that Anna would have hardly needed to emphasize in her masquing. She was already secure in a steady marriage, and all the greater populace had to do to determine her beauty was look at her. The fact that she was a mother was also obvious. Consequently, Anna took the opportunity that the masque afforded her to express aspects of her identity that she could not reasonable express elsewhere.

Anna's next masque caused quite a commotion at court. The Masque of Blackness was performed at Whitehall on Twelfth Night of 1605, and again the Queen had a starring role. This time, it was Ben Jonson who had been commissioned to write the masque, and given the author's mercurial relationship with the English court the controversial nature of this masque is not to be entirely unexpected. ${ }^{226}$ In this masque, the personification of Oceanus enters into a discourse with the personification of the Niger

\footnotetext{
${ }^{225}$ Anna would play Tethys in a later masque, Tethys Festival, but in that later masque Tethys was the central and most powerful female figure, rather than simply one amongst many.

${ }^{226}$ Richard Dutton, "Ben Jonson and the Master of Revels" in Theatre and Government Under the Early Stuarts by J.R Mulryne and Margaret Shewring (Cambridge: Cambridge University Press, 1993), 58-60. In his early years, Jonson had a few brushes with the law and only just escaped with his life after killing a fellow actor in a duel. During the Elizabethan era, Jonson seemed bent on rebellion against acceptable court behavior and mores. In 1599, Jonson was obliged to change the ending of his play Every Man Out of His Humour because it featured a rather unflattering depiction of the queen. Another work, Poetaster, was also amended after official intervention. It is notable that he dedicated the folio text of the work to his lawyer. By the end of James's reign, however, Jonson seems to have undergone a transformation: the youthful rebel had become, to quote Dutton, "the smooth-tongued panegyrist of dozens of court masques and aristocratic entertainments." Jonson also, however, seemed to suffer from a constant lack of confidence in himself and his work, and consequently was always careful to spell out his rights and expectations for remuneration in his contracts with his employers. He also insisted on maintaining the rights to his works, rather than transferring them to the acting company that performed them as was customary at the time.
} 
River. The Niger tells Oceanus that his twelve daughters ${ }^{227}$ (Anna and her eleven ladies) mourned because, although they were beautiful with their dark skin, they lacked the civilizing presence of the sun (King James and Brittania), and therefore were not as beautiful as they could be. The conversation is interrupted by the rising of the moon, Æthiopia, who tells Niger where his daughters can find the sun:

For were the World, with all his wealth, a ring, Britannia, (whose new Name makes all Tongues sing) Might be a Diamant worthy to inchase it, Rul'd by a Sun, that to this height doth grace it: Whose beams shine day, and night, and are of force To blanch an Athiope, and revive a Corse. His light sciential is, and (past meer nature) Can salve the rude defects of every creature. ${ }^{228}$

On the surface, this masque would not have struck the early modern English audience as being the least bit offensive: it is properly deferential to James, exalting him as a purifying and civilizing force amongst the dark and uncultured Ethiopians. There was one aspect of the masque, however, that shocked some members of the audience: Queen Anna had insisted that she and her ladies have their exposed limbs and faces coated in black makeup to imitate the Africans. This was not an invention of Ben Jonson, nor of Inigo Jones (who designed the sets and costumes), and Jonson seemed almost eager to give credit to (or blame) Anna for the idea: "Hence (because it was her Majesties will, to have them Black-mores at first) the Invention was derived by

\footnotetext{
${ }^{227}$ Ben Jonson, The Characters of Two Royall Masques. The One of Blacknesse, the Other of Beautie, Personated by Anne Queene of Great Britaine, \&C. with Her Honorable Ladyes (London: Imprinted for Thomas Thorp, 1608), 7-8.The roles were personated as follows: Queen Anna as Euphoris, the Countess of Bedford as Aglaia, Lady Herbert as Diaphane, the Countess of Derby as Eucampse, Lady Rich as Ocyte, the Countess of Suffolk as Kathare, Lady Bevill as Notis, Lady Effingham as Psychrote, Lady Elizabeth Howard as Glycyte, Lady Susan Vere as Malacia, Lady Wroth as Baryte, and Lady Walsingham as Periphere.

${ }^{228}$ Ibid., 7.
} 
me, and presented thus." ${ }^{229}$ Anna may have wanted to use make up to make a bold statement about the differences between the Africans and the "civilized" Europeans. One courtier, Dudley Carleton, noted that

Their apparel was rich but, some said, too light and courtesan-like for such great ones. Instead of vizards (masks) their faces and arms up the elbow were painted black, which was disguise sufficient enough and they were hard to be known, but it became them nothing so well as their own red and white... The Spanish and Venetian Ambassadors were both present at the masque, and sat by the King in state, at which Monsieur Beaumont quarrels so extremely that he says the whole Court is Spanish. But in this he should fall out with none but himself, for all were invited to come as private men to a private sport; which he refused, but the Spanish Ambassador accepted at once, and then saw no cause but that he should cast off the private man and become the Ambassador. In the first masque he sat amongst his men disguised, but afterwards he took out the Queen and did not forget to kiss her hand, though there was danger that it would leave a mark on his lips. ${ }^{230}$

This statement reasonably summarizes the complaints that some members of the audience had with this particular masque. It was unusual, and unbecoming, for a noblewoman to present herself in such attire, and even worse for her to blacken her skin. Acceptable costuming for a masque was somewhat different than what was acceptable on a public stage, partly because of the presence of female performers and partly because of the nature of the audience (in the case of the masque, only the nobility and select gentlemen and gentlewomen). In the court masque, while it was acceptable for a woman's breasts to be exposed or covered only by a sheer or gauzy material, it was considered uncouth for their arms, shoulders, or legs to be exposed. ${ }^{231}$ Anna herself was largely responsible for the costumes that were seen on stage in all the masques she produced. Although the designs were first created by an artist (usually Inigo Jones or Ben

\footnotetext{
${ }^{229}$ Ibid.

${ }^{230}$ G.B Harrison, A Jacobean Journal, 181-182.

${ }^{231}$ McManus, Women on the Renaissance Stage, 131.
} 
Jonson in Anna's case), the final decisions on color, cut, and materials were made by Anna. ${ }^{232}$ By exposing her arms, at least up to the elbows, on stage, Anna was going against an established social convention.

Anna was also visibly pregnant during this performance, which was perhaps the most blatant image of femininity that she could have displayed on stage. Anna's obvious pregnancy was shown into even sharper relief within the context of the masque's text and symbolism: the river daughters are given guidance by Æthiope in the guise of the moon. In Greek and Roman mythology, the moon was often associated with goddesses such as Artemis and Venus, who were in turn associated with fertility, pregnancy, and childbirth. ${ }^{233}$ On the other hand, there is also powerful symbolism of male fertility present as well, as is seen in the passage in which Æthiope tells the river daughters how to go about perfecting their beauty:

For which, you shall observe these Rites. Thirteen times thrice, on thirteen Nights, (So often as I fill my Sphere With glorious light, throughout the Year) You shall (when all Things else do sleep Save your chast Thoughts) with reverence, steep Your Bodies in that purer brine, And wholesome dew, call'd Ros-marine: Then with that soft, and gentler Fome, Of which the Ocean yet yields some, Whereof bright Venus, Beauties Queen, Is said to have begotten been, You shall your gentler Limbs ore-lave, And for your Pains, Perfection have. ${ }^{234}$

The river daughters are instructed to wash themselves in the sea foam, which gave birth to the Roman goddess of love, beauty, and fertility, Venus. In the myth of the birth of

\footnotetext{
${ }^{232}$ Bevington and Holbrook, The Politics of the Stuart Court Masque, 11-12.

${ }^{233}$ Edith Hamilton, Mythology (Boston: Little and Brown, 1942), 31-32.

${ }^{234}$ Jonson, The Characters of Two Royall Masques, 9.
} 
Aphrodite (the Greek counterpart of Venus), the goddess is born after her father had his genitals severed from his body and his semen mixed with the sea. ${ }^{235}$ According to Dr. Amy Greenstadt, an associate professor of English at Portland State University, it is an interesting use of imagery to have the river daughters wash themselves in the sea foam of Venus in order to cleanse themselves and achieve perfect beauty. In some ways, this imagery suggests that it is only through the intervention of the masculine aspect of fertility that the women are made whole. ${ }^{236}$

Whatever hackles she had raised by performing in Blackness, Anna had also taken a significant step in her creation of a female presence and identity on the stage in England. Her presence in the English masque performances was not entirely without precedence in Europe: in France at the court of Marie de Medici, the queen herself often performed in the Ballet de Cour with her ladies. ${ }^{237}$ In England, however, Anna was the first monarch to participate actively in a court theatre spectacle, and in doing so took the first step in opening up the stage for all women. Anna would never perform in a "public" setting (one that would have been open to the common people as well as to the select noble and gentle born that were invited to the court functions), yet she had certainly opened up a dialogue regarding the place of women on the stage.

It could be argued that the evolving role and image of women on stage was a part of the greater social change that was occurring in England during this time. Queen Elizabeth herself had shaken the core of English gender roles by ruling, reasonably

\footnotetext{
${ }^{235}$ Anne Baring and Jules Cashford, The Myth of the Goddess: Evolution of an Image (New York: Penguin Books, 1991), 352-353.

${ }^{236}$ I would like to take this opportunity to thank Dr. Greenstadt for her invaluable insights regarding this aspect of the court masque, as well as her willingness to share her knowledge and expertise during the development of this thesis.

${ }^{237}$ Graham Parry, The Golden Age Restor'd: The Culture of the Stuart Court, 1603-42 (New York: St. Martin's Press, 1981), 42.
} 
successfully, as an unmarried female monarch for forty-four years. Anna's active participation not only in the performance, but also in the production, of the court masque marks an increased female presence in yet another arena of English society. How can this increased female presence be tied to the identity that Anna was creating for herself, and could this identity be expanded to other women within the English nobility? There is no definitive proof that Anna was attempting to argue for an expanded role for all women, but within the context of her masques this message was certainly present. Anna had shifted the focus of the court masque away from male performers to female, which was a significant statement in itself; even though this shift was not as alarming as it would have been if it had taken place in a more politically charged arena, it was significant nonetheless. The gender line had been crossed. Anna's attitudes about female status stood in sharp contrast to those of Queen Elizabeth, who had had little interest in furthering the position or rights of women and who often was quoted as having said, "I may have the body of a weak and feeble woman, but I have the heart and stomach of a king." ${ }^{, 238}$ By opening up the court stage, Anna made strides for not only herself, but for her fellow noble and gentle women. ${ }^{239}$ Anna must have realized that pushing women to the forefront of the masquing stage would be pushing them further into the consciousness of the royal court as a whole. This act would have created a more public identity for Anna and for the ladies that she chose for her masques. Therefore, Anna was not only shaping her own identity through the court masque, but she was also shaping the identity of her favored noblewomen.

\footnotetext{
${ }^{238}$ Carole Levin, The Heart and Stomach of a King: Elizabeth I and the Politics of Sex and Power (Philadelphia: University of Pennsylvania Press, 1994), 1.

${ }^{239}$ Common women were, of course, still in the same situation that they had been in before, although whether this situation was more or less restrictive than that of noble and gentle women is open for debate.
} 
At the end of Blackness, the audience was assured that in one year's time they would be shown the results of the women's time in Britannia. This next masque, however, was postponed until 1608 when it was performed on the Sunday after Twelfth Night. Also written by Ben Jonson as a complement to Blackness, The Masque of Beauty once again starred Anna, but this time there was a significant change in the form of the masque since there were now sixteen ladies dancing instead of the previous twelve. ${ }^{240}$ Not all of the ladies who had danced in Blackness now appeared in Beauty. One of the most notable absences was that of Lady Penelope Rich, who had died the previous year. Amongst the newcomers were Lady Arbella Stuart and Lady Anne Clifford. ${ }^{241}$ The story began with a personification of the west wind, Boreas, bringing news to Januarius of the river daughters who had been led by the moon to Albion (England). The women, who had successfully been transformed into white-skinned beauties by the sun (again, representative of King James), had been delayed in their return journey by envious Night, who feared that her own dark hue would be scorned in the presence of the radiant young women. Then the east wind, Vulturnus, arrived and informed Januarius that the women were safe on a floating isle, and that they had constructed a Throne of Beauty upon which sat the world's soul, Harmony (Anna). ${ }^{242}$

After this exposition speech, a curtain on which Night had been painted was drawn back, and an isle floating on a calm sea was revealed. Atop the isle was the Throne of Beauty, and arranged around the throne amongst a series of pillars and colored lights

\footnotetext{
${ }^{240}$ Ben Jonson, The Characters of Two Royall Masques, 17.

${ }^{241}$ Ibid. Although there are no specific roles identified in Jonson's production notes for Beauty, the masquers were as follows: Queen Anna, Lady Arbella Stuart, the Countess of Arundel, the Countess of Bedford, the Countess of Derby, the Countess of Montgomery, Lady Elizabeth Gilford, Lady Katherine Peter, Lady Anne Winter, Lady Winsore, Lady Anne Clifford, Lady Mary Neville, Lady Elizabeth Hatton, Lady Elizabeth Garrard, Lady Chichester, and Lady Walsingham.

242 Ibid.
} 
were the masquers, personifying different aspects of ideal beauty: Splendor, Serenitas, Germinatio, Lætitia, Temperies, Venustas, Dignitas, Perfectio, and Harmonia. After the island arrived off the coast of Albion (a point on the stage directly in front of James), the river daughters were welcomed into the Thames, and two dances and songs were performed. According to Jonson's notes, James was so delighted by the performance that he requested that it be danced a second time. ${ }^{243}$ The symbolism in this piece is perhaps more obvious than the symbolism used in Blackness: the women, instead of acting in roles or costumes that could be perceived as subversive or shocking, are revealed to be proper English beauties who act as a balancing and harmonious force on the world against the temptations of the dark night. James is once again the civilizing and beautifying agent, and is therefore responsible for bringing harmony and beauty back into the world. It is interesting that Anna is cast in the role of a stabilizing agent, in this case Harmony, and yet she is still clearly in a position subservient to that of James.

One of the dominant themes in many of the masques that were performed during the reign of James and Anna was that of peace, usually with some representation of James as the bringer and maintainer thereof. Since this theme shows up not only in masques that James produced, but also those that Anna produced, it could imply that peace was an important aspect of foreign policy to her as much as it was to him. ${ }^{244}$ Alternatively, the theme of peace may have simply been a concession on Anna's part to James. It was a way to ensure that her masques were allowed to go on even with her more

\footnotetext{
243 Ibid.

${ }^{244}$ Holbrook, "Jacobean Masques and the Jacobean Peace" in Politics, 71. James produced several masques on his own, apart from those produced by Anna. While Anna tended to favor Ben Jonson and Samuel Daniel, James was a great patron of Thomas Campion. James often used the masques he produced to show special favor to his courtiers at special court events, such as weddings or state dinners.
} 
controversial subject material; by allowing the main theme to revolve around James as peacemaker, she was able to develop her own roles that personified a powerful woman of wit and courage. This is not to say that Anna was not interested in peace, but merely that it was probably less important in her masquing than it was in her husband's masques or his own political agenda.

The masque Beauty seems to be almost an apology for its predecessor: not only does it directly apologize for the delay in production (the conversation between the Boreas and Januarius), but its raison d'être seems to be more of a visual feast rather than any sort of allegorical message. Beauty recycles most of its conceit (storyline) from Blackness, but with the conversation between Boreas, Januarius and Vulturnus instead of between Oceanus, Niger, and Æthiopia, and with sixteen beautiful white women instead of twelve blackened women. And James is still the sun that draws the women, even after their transformation. It is no wonder that he was so pleased with the end result: there was nothing even remotely threatening or questionable in the entire production. It was, for all intents and purposes, a display of royal wealth, sumptuousness, and benevolence. The remarks made by Ambassador Guistiniani sum up the event neatly:

I must just touch on the splendour of the spectacle, which was worthy of her Majesty's greatness. The apparatus and the cunning of the stage machinery were a miracle, the abundance and beauty of the lights immense, and the music and dance most sumptuous. But what beggared all else and possibly exceeded the public expectation was the wealth of pearls and jewels that adorned the Queen and her ladies, so abundant and splendid that in everyone's opinion no other court could have displayed such pomp and riches. ${ }^{245}$

\footnotetext{
${ }^{245}$ Ben Jonson, Charles Harold Herford, Percy and Evelyn Simpson, eds. Ben Jonson: An Historical Survey of the Text. The Stage History of the Plays. Commentary on the Plays, Vol. X: Play Commentary. Masque Commentary (Oxford: The Clarendon Press, 1950), 457.
} 
Clearly, this night did not belong to Anna. Despite the gracious praise of the ambassador, the focus was on the stage works (giving due credit to the genius of Ben Jonson and Inigo Jones) and the relative wealth that was displayed on the stage, rather than on any particular innovation on Anna's part or any powerful statement made by her. Under most circumstances, this was to be expected: since the masquers themselves did not speak, they were dependent upon the spectacle of the masque to enhance their own symbolic power. For this masque, it seems as though the message set forth by the costumes and scenery was one of wealth and excess rather than of feminine autonomy or authorship. This performance could have set the tone for all of Anna's future masques, but it clearly did not. It can be argued that Anna's next performance in The Masque of Queens was her most powerful.

When Anna brought the masque to the forefront of court culture, she also brought it to the forefront of court politics. Anna understood that the masque provided her with a medium in which to promote her own political goals and ambitions. Martin Butler, in his essay title "Courtly Negotiations," summarizes the political masque as a ground of challenge and confrontation:

Masques sponsored by the Queen, by dissident noblemen, by critics of Jacobean pacifism and Caroline absolutism must scarcely less have borne the character of ceremonial confrontations. In such cases, the symbolic contests were unsettling and did not testify unproblematically to the monarch's transcendence. On the contrary, they opened up precisely the possibility that, just occasionally, domination might not always be dominating. ${ }^{246}$

The Masque of Queens Celebrated in the House of Fame was performed at Whitehall on 2 February 1609 and was Anna's fourth performance. It was Jonson's third time working

\footnotetext{
${ }^{246}$ Martin Butler, "Courtly Negotiations" in The Politics of the Stuart Court Masque, ed. by David M. Bevington and Peter Holbrook (Cambridge: Cambridge University Press, 1998) 37.
} 
with the queen. It was also the first instance of an ante-masque being used as a precursor to one of Anna's main masques, an idea that Jonson attributes to Anna herself:

And because her Majesty (best knowing, that a principal part of life, in these Spectacles, lay in their variety) had commanded me to think on some Dance, or Shew, that might precede hers, and have the place of a foil or false Masque. ${ }^{247}$

In this case, the ante-masque involved twelve witches or hags (one for each lady in the main masque) that personified characteristics oppositional to those in the house of Fame. ${ }^{248}$ These witches were shown to participate in magic most foul, slaughtering dogs, cats, and even human infants to acquire ingredients for their malicious brew. They disrupted the natural elements, causing great storms. ${ }^{249}$ The witches began an unnatural and wild dance, which was then interrupted by a blast of loud music, at which time they scurried back into the hell from whence they came, and the entire stage changed appearance. In place of the entrance to hell was the house of Fame, on which the twelve ladies were arranged in a pyramid formation on a triumphal throne. The figure of Perseus, Heroick Vertue, then appeared and introduced the twelve great queens of history that occupied the house of fame. ${ }^{250}$

This is where the Masque of Queens becomes interesting: each of the twelve queens represented in the masque were great warrior queens:

\footnotetext{
${ }^{247}$ Ben Jonson, Clark Holloway, ed.,The Masque of Queens, Celebrated in the House of Fame, (London: William Stansby, 1616), last date updated: 2003, $<$ http://hollowaypages.com/jonson1692fame.htm>.

${ }^{248}$ Ibid. The twelve witches were Ignorance, Suspicion, Credulity, Falsehood, Murmur, Malice, Impudence, Slander, Execration, Bitterness, Rage, and Mischief.

${ }^{249}$ The element of witchcraft was an interesting addition on Jonson's part, given the history of James and Anna's journey from Denmark to Scotland and the accusations of witchcraft that had resulted from the difficult sea voyage.

${ }^{250}$ Jonson, Clark Holloway, ed. Masque of Queens. Unfortunately, this is another masque in which there is no listing of which woman played which role, with the exception of Anna. The other ladies present were the Countesses Arundel, Derby, Huntington, Bedford, Essex, and Montgomery, the Viscountess Cranford, and the Ladies Elizabeth Guilford, Anne Winter, Winsore, and Anne Clifford.
} 
In yond' bright Bevie, each of them a Queen.

Eleven of them are of times, long gone.

Penthesilea, the brave Amazon,

Swift-foot Camilla, Queen of Volscia,

Victorious Thomyris of Scythia,

Chaste Artemisia, the Carian Dame,

And fair-hair'd Beronice, Agypt's fame,

Hypsicratea, glory of Asia,

Candace, pride of Athiopia,

The Britain honour, Voadicea (Boudicca)

The vertuous Palmyrene, Zenobia,

The wise, and warlike Goth, Amalasunta,

And bold Valasca, of Bohemia

The final warrior queen, and the queen portrayed by Anna, was Bel-Anna, the queen of the oceans. Bel-Anna possessed all possibly virtues, and was therefore the leader of the rest. $^{251}$

In her essay "Anne of Denmark and the Subversions of Masquing," Barbara Lewalski states that the Masque of Queens should be read as a subversive action on the part of Anna: that since it features historical queens who ruled in their own right, it is an open bid on the part of Anna to transfer power from the king to the queen. ${ }^{252}$ The idea for the heroine queens had, after all, been Anna's. However, it is also important to note that when Jonson wrote the masque, he wrote the role of Heroick Vertue, as the character Perseus, a man. Jonson was careful to cater to Anna's wishes, while still trying to leave a masculine presence in the position of utmost authority and power. ${ }^{253}$ This provides a sharp reminder that, despite the amount of influence and input Anna would have had when it came to the court masques, she was still dependant upon Jonson to write them.

\footnotetext{
251 Ibid.

${ }^{252}$ Barbara Lewalski, “Anne of Denmark and the Subversions of Masquing," Criticism 35 (1993), 346.

${ }^{253}$ Stephen Orgel, "Marginal Jonson," in The Politics of the Stuart Court Masque by David Bevington and Peter Holbrook, 164.
} 
Yet this masque is still a potent symbol of who Anna was and what she conceived herself as representing.

Anna had spent her years with James as a woman trying to carve out a place for herself in a court that was ill-prepared to receive her. She maintained a significant sense of pride in her heritage as the daughter and sister of Danish kings, and as the wife and mother of English and Scottish kings. The Masque of Queens reflects Anna's identity as a woman of independent royal status, not one dependant on the status of her husband. BelAnna represented all the best virtues amongst the warrior queens in one woman, a concept that probably would have appealed to Anna. Although she had not fought in any wars, Anna had already had to fight many battles with her husband over the custody of her children and over the rights and protections of her ladies and her friends, and so she would have had a common bond with the ancient warrior queens. She had selected this theme for a reason, and whether that reason was to argue actively for a transfer of power from king to queen or simply to assert her personal authority as a queen consort, it suited her well.

It is also interesting to note that Anna's role was the only one that was not based on a historical queen, but rather a mythological queen who encompassed all of the positive qualities of the heroic queens of the past. Why did Anna choose to identify with Bel-Anna instead of one of the other queens? The fact that Bel-Anna is unique and separate indicates that Anna was suggesting that she was one of a kind; that there was no historical queen with whom to compare her, nor would there ever be one in the future, because she represented an ideal that could not possibly be duplicated. By portraying the role for Bel-Anna, Anna was also making a distinction between herself and her ladies by 
selecting a mythological role while they were limited to terrestrial roles. Anna's choosing

to represent Bel-Anna is another instance of her constructing an identity via the masque.

The response from the court regarding this masque and Anna's role in it is unknown,

perhaps because of the material, but it is likely that James was less enthusiastic about this masque than he had been about the Masque of Beauty since it featured women in a much more powerful and assertive role.

Anna's next masque was written by Samuel Daniel instead of Ben Jonson, and was performed at Whitehall on 5 June 1610 to celebrate the investiture of Prince Henry as the new Prince of Wales. Anna played the role of Tethys, the queen of the ocean, and thirteen of her ladies (including Princess Elizabeth, as noted in the previous chapter), portrayed the nymphs of various rivers in England. ${ }^{254}$ The ante-masque ${ }^{255}$ was simple, and involved a young Prince Charles in the character of Zephyrus announcing the imminent arrival of Tethys and the other nymphs, as well as presenting the queen's gifts to James and Henry (a trident to James, the "king" of the ocean, and a sword and scarf to Henry). ${ }^{256}$ This masque was not written for any agenda of Anna's, other than to celebrate the elevation of her son. The songs praise him, and speak of the glory that he will one day

\footnotetext{
${ }^{254}$ Samuel Daniel, Tethys Festival: or, The Queen's Wake, 309-310. The other ladies present were Lady Arbella Stuart as the nymph of the Trent, the Countess of Arundel as the nymph of the Arun, the Countess of Derby as the nymph of the Darwent, the Countess of Essex as the nymph of the Lee, the Countess of Dorset as the nymph of the Ayr, the Countess of Montgomery as the nymph of the 20 Severn, the Viscountess of Hadington as the nymph of the Rother, Lady Elizabeth Gray as the nymph of the Medway, Lady Elizabeth Guilford as the nymph of the Dulesse, Lady Katherine Peter as the nymph of the Olwy, Lady Winter as the nymph of the Wy, and Lady Winsore as the nymph of the Uske.

${ }^{255}$ In Ben Jonson's original notes, he spells the word "anti-masque." This is cause for some confusion as to whether he was trying to express that this was the portion of the masque that came before the main masque, in which case the more correct spelling would have been "ante-masque," or if he was trying to express that this part of the masque was meant to serve as a foil to the main masque, as was almost always the case. In this latter case, "anti-masque" would be more correct. Since there is no way to know for certain what Jonson intended, for the sake of this paper "ante-masque" will be used.

${ }^{256}$ Daniel, Tethys Festival, 309-310.
} 
bring to England. ${ }^{257}$ It is likely that Anna would have had some input in the creation of the masque and specifically asked Daniel to create a conceit that dealt with water, sailing, and navigation, since these were some of Henry's great loves. Anna herself, as has been previously mentioned, had been afraid of boats and open water since her difficult crossing from Denmark to Scotland, and it is unlikely that Daniel would have written such a masque without her direct consent and approval.

The final masque in which Anna performed was Ben Jonson's Love Freed From Ignorance and Folly, which was presented sometime in 1611. Unfortunately, there is little surviving information about this masque beyond the barest text itself. There is no cast listing, and there are very few production notes, although it is noted that Anna played the role of the Queen of the Orient. The conceit is simple enough: Cupid, the personification of Love, is captured by a Sphinx, personifying ignorance. The two debate and, finally, the Sphinx allows Cupid an opportunity to win his freedom, provided that Cupid can answer a riddle:

First, Cupid, you must cast about To find a World the World without, Wherein what's done, the Eye doth do; And is the light, and treasure too. This Eye still moves, and still is fixed, And in the powers thereof are mixed Two Contraries; which time, till now, Nor Fate knew where to join, or how. Yet, if you hit the right upon, You must resolve these, all, by one. ${ }^{258}$

Cupid, of course, is eventually able to solve the riddle:

\footnotetext{
${ }^{257}$ Ibid., 315.

${ }^{258}$ Ben Jonson, Clark Holloway, ed., Love Freed From Ignorance and Folly: A Masque of Her Majesties (London: William Stansby, 1616), last date updated: 2003,

<http://hollowaypages.com/jonson1692love.htm>.
} 
'Tis done, 'tis done. I have found it out,

Britain's the World, the World without.

The King's the Eye, as we do call

The Sun the Eye of this great All.

And is the Light and Treasure too;

For 'tis his Wisdom all doth do.

Which still is fixed in his brest,

Yet still doth move to guide the rest.

The Contraries which Time till now

Nor Fate knew where to join, or how,

Are Majesty, and Love; which there,

And no where else, have their true Sphere. ${ }^{259}$

In the end, Cupid is freed because he correctly guesses that Albion, or England, is the answer to the riddle. James is once again celebrated as the redeeming sun of the world, replete with wisdom, majesty, and love.

This masque seems a far cry from Anna's earlier efforts; in fact, there is no discernible trace of her influence or input at all, which may be why Ben Jonson put so little effort into his production notes. Why, though, is Anna's presence not tangible in her final performance piece? Her choice of role is the obvious one (that of a queen), but there is very little additional symbolism attached to the role. It is possible that, at this point, Anna determined that the masque had served as much purpose as it was going to, and this was the first step in her slow withdrawal from the art form. She would assist in the production of two more masques, but would not perform in any beyond Love Freed. It is also important to note that, once Prince Henry turned 18, Anna had more competition when it came to the staging of major court events as her son began sponsoring his own events, employing Ben Jonson as well. ${ }^{260}$ The masques, being one of the most expensive

\footnotetext{
259 Ibid.

${ }^{260}$ Ben Jonson, Clark Holloway, ed., The Speeches at Prince Henry's Barriers (London: William Stansby, 1616), last date updated: 2003, <http://hollowaypages.com/jonson1692speeches.htm>; Ben Jonson, Clark
} 
entertainments at court, ${ }^{261}$ were usually limited to one per season, unless a wedding or visiting monarch occasioned another, usually smaller, masque. With Henry's growing interest in the form, Anna would have found it in his best interest to begin simply loosening her attachment to the masque to allow her son an opportunity to amplify his own image and present himself as the glorious heir to the throne. Anna had already proven that she wanted to promote Henry and his interests, and this would have been seen as a necessary sacrifice to continue that promotion. After Henry's death, Anna seemed to lose interest in the masque altogether, perhaps out of grief, or perhaps because she decided that the court masque had taken her as far as it was going to.

Holloway, ed., Oberon, the Fairy Prince: A Masque of Prince Henry's, last date updated: 2003, $<\mathrm{http}: / /$ hollowaypages.com/jonson1692oberon.htm>.

${ }^{261}$ Holbrook, "Jacobean Masques and the Jacobean Peace" in Politics, 67. 
Chapter Five: Conclusion

Anna of Denmark died on 2 March 1619 at around 3:00 in the morning in the presence of her son, Charles, the Archbishop of Canterbury, the Bishop of London and her doctors. Her cause of death was most likely a combination of heart disease and complications from gout, an ailment from which she frequently suffered. The records in the Calendar of State Papers Domestic for that year state that she died "having benefited many and injured none. She died most willingly and was more comely in death than ever in life." ${ }^{262}$ Therefore, she died in keeping with the early modern beliefs regarding how to die well. She was forty-five years old. Unfortunately, Anna's funeral had to be delayed until 13 May because there was simply no money to put on the elaborate and lavish ceremony that James wanted for the queen. ${ }^{263}$ In her diary, Lady Anne Clifford describes the final moments of the service:

When all the company was gone and the church door shut up by the Dean of Westminster, then the prebends and Sir Edward Zouch, who was Knight Marshall, came up the private way and buried the corpse at the east end of Henry the Seventh chapel about 7 o' clock at night. ${ }^{264}$

Allegedly, Anna's viscera were buried in a separate, Catholic ceremony in a final attempt by her Catholic friends to honor the queen's religion. ${ }^{265}$ After her complicated marriage, the trauma of fighting for the custody of her eldest son and his premature death, and her struggle to carve out an identity at both the Scottish and English courts, Anna was finally at peace.

\footnotetext{
${ }^{262}$ Green, Calendar, 25.

${ }^{263}$ John Chamberlain, N.E McClure, ed., The Letters of John Chamberlain, Vol. 2, 224.

${ }^{264}$ Clifford, Diary, 101.

${ }^{265}$ McManus, Women on the Renaissance Stage, 205.
} 
What was Anna's legacy? This thesis has attempted to answer these questions by examining the ways in which Anna was able to exercise both intelligence and personal agency through her roles as a royal wife and mother. Despite having her power limited by her position as a queen consort as opposed to a queen regnant, Anna was able to analyze and manipulate court factions and politics to achieve her own ends.

As a mother, it is debatable whether Anna's greater legacy was her son Henry, her only surviving son, Charles, or her daughter, Elizabeth. It had been Henry who seemed to have taken after his mother the most, not only in his outward appearance, but in his demeanor and his personal values as well. Of her three children, Anna had certainly invested the most time in Henry for better or for worse, and so it is unsurprising that he should seem so much like his mother. These similarities speak for the influence that Anna had as a mother. Even the long and bitter battle for the custody of Henry must have had an effect on the young prince: Henry must have realized that he was extremely important to his mother. One of the favorite questions of historical imagination is what would have happened if Prince Henry had lived. While most of these scenarios revolve around the outcome of the English Civil Wars and whether or not these wars would have happened at all, it also raises questions about how Anna would have been remembered by history. If she had been the beloved mother of a successful king, would Anna have been less maligned by later historians than she has been as the mother of Charles? As it stands, it is necessary for historians to look instead at Anna's legacy as a mother to Charles and Elizabeth.

On the one hand, it was Charles who would inherit the English and Scottish thrones upon the death of his father. Charles had certainly inherited his mother's love of 
the fine arts, but this characteristic is unlikely to have translated to any sort of significant aspect of his reign. Instead, if any negative link can be made between the reign of Charles and his mother it would have been Anna's own pride in her royal heritage and prerogative. It was this pride that she almost certainly would have passed down to her own children, which would have had a more significant impact on her son's reign and, eventually, his downfall. Anna had also, however, made an effort to connect with her common subjects, something that Charles never really seemed to imitate. Anna cannot be blamed for Charles' lack of success, nor can she be blamed for the devastating consequences of his failed reign; rather, she almost certainly influenced him in some positive ways.

From the scant information available regarding the two women, it is difficult to determine whether or not Anna had any significant influence on her daughter's life beyond the character traits that Elizabeth inherited from her mother. Perhaps the most that can be said about Anna's legacy as it relates to Elizabeth is, as noted previously, that her daughter's progeny would be the Hanoverian line of kings of England. Anna seemed to want the best for her daughter, but there is simply not enough information regarding their relationship to determine if Elizabeth's life was influenced by Anna in either a positive or negative way.

Anna also left her mark, albeit faintly perhaps, on the emerging question of women's status in England in the early modern period. To say that she was a feminist would be to overlay a modern definition over an early modern understanding of the world, and would do little to further scholarly understanding of what Anna was able to do and what her motivation was for doing it. There are at least two clear and prominent 
examples of Anna advocating for a woman at court, even though it meant opposing the king: the cases of Arbella Stuart and Lady Anne Clifford, but was the fact that these were women a determining factor in her decision to advocate on their behalf? Given that Anna was equally supportive of Walter Raleigh, it seems more likely that Anna was simply advocating for those courtiers that she liked. The noteworthy point here is that Anna was just as likely to support a woman as she was a man, and that the relative status of male and female courtiers was irrelevant to her advocacy.

What is more interesting about Anna's advocacy for Arbella Stuart and Lady Anne Clifford is that both of these cases required Anna to act in opposition to King James and, in Lady Anne's case, against a male courtier. In one of these examples Anna was not successful in her advocacy, in the other she was. The case of Arbella Stuart was an instance of Anna's direct intervention, and illustrates the loyalty she felt towards the members of her household. Anna not only supported Arbella's attempts to find a suitable husband, but even after Arbella's fall from grace and her death she tried to convince her husband to allow the court to go into mourning for the woman who was, and had been treated as, a member of the royal family. Unfortunately for both women, James was still living under the shadow of uncertainty and suspicion that was a result of his early years. This tendency to suspect the worst of his own kin made him less inclined to forgive Arbella for her offenses or to allow Anna to mourn publicly for her lady-in-waiting.

The case of Lady Anne Clifford was an instance of Anna's indirect intervention, but one that shows a stronger example of Anna's support for a noblewoman's interests. Anna encouraged Lady Anne to stand up for herself not only against the king, but against her own husband, which may have been an even more serious act. Lady Anne's own 
diary attests to the fact that it was Anna's support behind the scenes that allowed her to act against her husband's wishes and the wishes of her king. This is also a testament to Lady Anne's faith in her queen: Lady Anne's refusal to accept the offer that King James made regarding her inheritance could have backfired badly, and yet she chose to follow Anna's advice nonetheless. Anna's willingness to stand behind Lady Anne on the matter would make all the difference in the end.

The efforts that Anna made to advocate for or against other individuals at her husband's court shows a distinct attempt on the part of the Queen to express personal agency and to try and carve out a niche for herself in the larger world of court politics that was not limited to producing children and acting as an ornament for her husband. These attempts by Anna were, in reality, rarely successful. Her daughter Elizabeth married Count Frederick V despite Anna's concerns. Walter Raleigh was still executed even though Anna had vigorously defended him. Finally, George Villiers was still selected as the new court favorite to replace Robert Carr, although Anna had initially pointed out (correctly) that Villiers would be no better than Carr when it came time to remember those who had put him in power. This particular instance is uniquely important because this is a known example of male courtiers actively seeking out Anna's insight and support. Not only were these courtiers male, they were also Protestant, yet they still valued Anna's patronage and support. This indicates that these men recognized Anna's understanding of court politics and her ability to influence her husband and his appointments. Anna's importance here cannot be measured in successes or failures, but rather in the attempts themselves. Anna never tried to defend someone that she did not honestly feel deserved it, despite popular opinions or pressures from the court (except 
probably George Villiers). These actions that she took in the defense or the condemnation of an individual show that she understood the way the court worked and the political undercurrents at play during her husband's reign. Anna's actions also paint a picture of a woman who was not content to accept a situation simply because it was the will of her husband. Anna was determined to make her own voice heard.

Most impressive, perhaps, is the impact that Anna had on the world of English theater, and the way she used the court masque to craft an identity for herself. Although the masque form had existed in England before the reign of James VI/I, the court masque that Anna nurtured and developed was a unique creation that made its debut under her aegis. For the first time, noblewomen were given a place on the stage and, consequently, were given an opportunity to express themselves through costume, dance, and character in a way that had never been available to them previously.

Anna herself took particular advantage of this, and used the stage and the characters she chose to portray as a means of expressing her ideals and the role she wanted to play in the English court, and she was the first woman ever to do so. Because the masque was an art form (albeit with political overtones) rather than a distinct political arena, Anna was able to express herself and her ideas about her identity with relative safety in this venue, and she used this opportunity to the fullest. It is entirely possible that modern scholars can learn more about who Anna was and who she wanted to be by looking at her roles in the masques than by looking at any other aspect of her life. It was in the court masque that Anna attempted to establish an identity for herself in a way that had never been used by women before. Anna also used the masque to express her opinions about religion, war, and politics. The masque provided Anna with a forum that 
she would have been denied elsewhere. By placing herself and her ladies at the center of the court stage, Anna was (intentionally or not) opening the door for other women to take the stage after her, and in much more dramatic and public ways.

For a queen consort like Anna, the court masque would have been invaluable as a forum for her political expression. Anna would not have been able to state her opinions about state matters or policy openly, but she could express them subtly through the roles she chose to play, the design of the costumes, and even the plot of the masque to some degree. While she was always careful to pay proper homage to James within the context of the masque, there is no question that she also asserted her own royal status and her own political values and opinions. In fact, much of the modern analysis that has been done about Anna's politicking has been done within the context of her masquing career.

Anna of Denmark, the wife of King James VI/I of Scotland and England, was an interesting and intriguing historical figure. While she displayed different intellectual qualities than those held and prized by her husband, her actions during her time as queen illustrate a type of intellect and understanding that exemplify the intelligence and awareness that make her an ideal example of a Renaissance queen. Although she was rarely able to participate directly in court politics, Anna led an active life and was an ardent patron of the arts at court, particularly the court masque. Although she was a queen consort as opposed to a queen regnant, she was able to make the most of her position and carve out a place for herself.

Anna was able to express agency and autonomy through her masquing, her interactions with her husband and children, and her involvement in court politics and her understanding of human nature. Anna, it could be argued, understood people better than 
her husband ever would, and she was not afraid to vocalize her opinions when she disagreed with her husband's decisions regarding those people. Modern scholars have only recently begun to examine Anna through the various facets of her life as this thesis does, rather than simply as the wife of King James.

Ultimately, this research has shown that such an approach can yield a fuller and more complex and interesting portrait of Anna than was previously possible. The goal has been to add to the current historiography not only regarding Anna and her biography, but to the wider understanding of English queens consort and the even broader field of women's history. Queens consort did not have the same access to direct power that either their husbands or queens regnant did, and consequently they had to seek alternative routes to achieve their goals and realize their own desires. Studying Anna of Denmark as an ideal example of a queen consort does exactly that. Furthermore, examining the ways in which Anna filled her roles as a royal wife and mother illustrates how a queen could use these roles to exert both political and social influence. Finally, Anna of Denmark provides a unique opportunity for historians to study a queen consort who developed and maintained a court that was separate from that of her husband, which was a rare occurrence in England. It is time for Anna to take her place amongst other intelligent and active queens consort, such as Eleanor of Aquitaine and Katherine Parr, rather than remaining in the shadows of history. 


\section{$\underline{\text { Sources Consulted }}$}

\section{Primary Sources}

Akrigg, G.P.V., ed. Letters of King James VI \& I. Berkeley, CA: University of California Press, 1984.

Birch, T. The Life of Prince Henry of Wales. London: Printed for A. Millar in the Strand, 1760.

British History Online. Calendar of the Cecil Papers in Hatfield House, Volume 16: 1604. Last date updated: 2011. < http://www.britishhistory.ac.uk/report.aspx?compid=112201>.

British History Online. Calendar of State Papers Domestic, August-September 1603. Last date updated: 2011. <http://www.britishhistory.ac.uk/report.aspx?compid=14988>

British History Online. Calendar of State Papers Domestic, November 1612. Last date updated: 2011. < http://www.british-history.ac.uk/report.aspx?compid=51467>.

British History Online. Calendar of State Papers Venetian, 1603-1607. Last date updated: 2011. < http://www.british-history.ac.uk/source.aspx?pubid=1009>.

British History Online. Calendar of State Papers Relating to English Affairs in the Archives of Venice, Volume 12: 1610-1613. Last date updated: 2011. < http://www.british-history.ac.uk/source.aspx?pubid=1011>.

Campion, Thomas. A relation of the late royall entertainment giuen by the Right Honorable the Lord Knovvles, at Cawsome-House neere Redding: to our most gracious queene, Queene Anne, in her progresse toward the Bathe, vpon the seuen and eight and twentie dayes of Aprill. 1613 VVhereunto is annexed the description, speeches, and songs of the Lords maske, presented in the Banquetting-house on the mariage night of the high and mightie, Count Palatine, and the royally descended the Ladie Elizabeth. Written by Thomas Campion. London: William Stansby, 1613.

Carey, Robert. Memoirs of the Life of Robert Cary, Baron of Leppington and Earl of Monomoth. London: printed by J. Hughs for R. and J. Dodsley, 1759.

Castiglione, Baldassare. The Book of the Courtier. London: David Nutt in the Strand, 1900.

Chamberlain, John, Thomson, Elizabeth McClure, ed. The Chamberlain Letters: A Selection of the Letters of John Chamberlain Concerning Life in England from 1597-1626. Toronto: Capricorn Books, 1966.

Chamberlain, John, N.E McClure, ed. The Letters of John Chamberlain, 3 Vols. Philadelphia: American Philosophical Society, 1939.

Clifford, Lady Anne, Isabella Barrios, ed., Vita Sackville West, introduction. The Diary of the Lady Anne Clifford, 1590-1676. Boulder, CO: Aardvark Press, 1997. 
Coke, Roger. A Detection of the Court and State of England During the Four Last Reigns and the Inter-Regnum. London: Printed for Andr. Bell, 1697.

Constable, Archibald, Walter Balcanquhall, Anne, Robert Johnston, and George Heriot. Extracts from Accounts and Vouchers Relative to Jewels Furnished by George Heriot to Anne of Denmark. Edinburgh: Printed for Archibald Constable, 1822.

Daniel, Samuel. The Queenes Arcadia. A Pastorall Trago-Comedie Presented to Her Maiestie and Her Ladies, by the Vniuersitie of Oxford in Christs Church, in August Last, 1605. [In Verse. With a Dedicatory Epistle, 'To the Queenes Most Excellent Maiestie.' By Samuel Daniel.]. London: G. Eld for Simon Waterson, 1606.

Daniel, Samuel. Tethys Festival: or, The Queen's Wake. London: Printed for John Budge, 1610.

Daniel, Samuel, Ernest Law, ed. The Vision of the Twelve Goddesses: A Royal Masque. London: Bernard Quaritch, 1880.

Green, Mary Anne Everett, ed. Calendar of State Papers, Domestic Series, of the Reign of James I. 1611-1618, Preserved in the State Department of Her Majesty's Public Record Office. Nendeln [Liechtenstein]: Kraus Reprint Ltd., 1967.

Halliwell, J.O, ed. Letters of the Kings of England Vol. II. London: H. Colburn, 1848.

Harrison, G.B., ed. A Jacobean Journal: Being a Record of Those Things Most Talked of During the Years 1603-1606. London: George Routledge and Sons. 1946.

Historic Manuscript Comission. Report on the Manuscripts of the Earl of Mar and Kellie. London: Ben Johnson and Co., 1904.

Jonson, Ben. The Characters of Two Royall Masques. The One of Blacknesse, the Other of Beautie, Personated by Anne Queene of Great Britaine, \&C. with Her Honorable Ladyes 1605 and 1608, Etc. (The Description of the Masque. With the Nuptiall Songs. Celebrating the Happy Marriage of Iohn, Lord Ramsey, Viscount Hadington At Court on the Shroue-Tuesday 1608.). London: Imprinted for Thomas Thorp, 1608.

Jonson, Ben. Charles Harold Herford, Percy and Evelyn Simpson, eds. Ben Jonson: An Historical Survey of the Text. The Stage History of the Plays. Commentary on the Plays, Vol. X: Play Commentary. Masque Commentary. Oxford: The Clarendon Press, 1950.

Jonson, Ben. Clark Holloway, ed. Love Freed From Ignorance and Folly: A Masque of Her Majesties. London: William Stansby, 1616. Last date updated: 2003. <http://hollowaypages.com/jonson1692love.htm>.

Jonson, Ben. Clark Holloway, ed. The Masque of Queens, Celebrated in the House of Fame, 1609. London: William Stansby, 1616. Last date updated: 2003. < http://hollowaypages.com/jonson1692fame.htm> 
Jonson, Ben. Clark Holloway, ed. Oberon, the Fairy Prince: A Masque of Prince Henry's. London: William Stansby, 1616. Last date updated: 2003. <http://hollowaypages.com/jonson1692oberon.htm>

Jonson, Ben. Clark Holloway, ed. A Particular Entertainment of the Queen and Prince Their Highness at Althorpe, 1603. London: William Stansby, 1616. Last date updated: 2003.

< http://hollowaypages.com/jonson1692queen.htm>

Jonson, Ben. Clark Holloway, ed. The Speeches at Prince Henry's Barriers. London: William Stansby, 1616. Last date updated: 2003. $<$ http://hollowaypages.com/jonson1692speeches.htm>.

Lodge, Edmund. Illustrations of British History, Vol. III. London: J. Chidley, 1838.

Melville, Sir James, T. Thomson, ed. Memoirs of His Own Life by Sir James Melville of Halhill, 1549-1593. Edinburgh: Bannatyne Club, 1827.

Monthly Review, The, or Literary Journal: From January to June, inclusive. By Several Hands, Vol. 68. London: Printed for R. Griffiths, 1783.

Naille, Robert. A Relation of the Royall, Magnificent, and Sumptuous Entertainement Giuen to the High, and Mighty Princesse, Queene Anne, at the Renowned Citie of Bristoll, by the mayor, sherrifes, and aldermen thereof; in the moneth of Iune last past 1613. London: Printed for John Budge, 1613.

Nichols, John, ed. The Progresses, Processions, and Magnificent Festivities of King James I, His Royal Consort, Family, and Court, vol. III. New York: Burt Franklin, 1967.

Parr, Katherine, Janel Mueller, ed. Katherine Parr: Complete Works and Correspondence. London; Chicago: University of Chicago Press, 2011.

Rimbault, Edward F. The Old Cheque-book or Book of Remembrance of the Chapel Royal. London: Camden Society, 1872.

Stuart, Lady Arbella, Steen, Sara Jayne, ed. The Letters of Lady Arbella Stuart. Oxford: Oxford University Press, 1994.

The Monthly Review, or Literary Journal: From January to June, inclusive. By Several Hands, Vol. 68. London: Printed for R. Griffiths, 1783.

Williamson, Hugh Ross. George Villiers, First Duke of Buckingham, Study for a Biography. London: Duckworth, 1940.

Secondary Sources

Allinson, Rayne, Liz Oakley-Brown, and Louise J. Wilkinson, ed. The Rituals and Rhetoric of Queenship: Medieval to Early Modern. Dublin; Portland: Four Courts Press, 2009.

Akrigg, G. P. V. Jacobean Pageant; Or, The Court of King James I. Cambridge, MA: Harvard University Press, 1962. 
Baring, Anne and Jules Cashford. The Myth of the Goddess: Evolution of an Image. New York: Penguin Books, 1991.

Barroll, J. Leeds. Anna of Denmark, Queen of England: A Cultural Biography. Philadelphia: University of Pennsylvania Press, 2001.

Bellamy, Alastair. The Politics of Court Scandal in Early Modern England: News Culture and the Overbury Affair, 1603-1660. Cambridge: Cambridge University Press, 2002.

Bellesheim, Alphons. History of the Catholic Church in Scotland, Vol. III. Edinburgh: London: Blackwood, 1887.

Bevington, David M., and Peter Holbrook. The Politics of the Stuart Court Masque. Cambridge: Cambridge University Press, 1998.

Butler, Martin. The Stuart Court Masque and Political Culture. Cambridge: Cambridge University Press, 2008.

Chalmers, Hero. "'Break Up the Court': Power, Female Performance and Courtly Ceremony in Henry VIII." Shakespeare 7, no. 3 (2001): 257-268.

Christianson, J. R. “The Legacy of Tycho Brahe.” Centaurus 44, (2002): 228-247.

Cox, John D., and David Scott Kastan. A New History of Early English Drama. New York: Columbia University Press, 1997.

Donaldson, Gordon. The Edinburgh History of Scotland, Volume 3: James V-James VII. Edinburgh: Oliver and Boyd, 1971.

Dutton, Ralph. English Court Life from Henry VII to George II. London: B.T. Batsford Ltd., 1963.

Gregg, Pauline. King Charles I. Berkeley, CA; Los Angeles: University of California Press, 1984.

Gristwood, Sarah. Arbella: England's Lost Queen. Boston, MA; New York: Houghton Mifflin Company, 2003.

Haigh, Christopher. Elizabeth I. Harlow; London; New York: Longman, 2001.

Hamilton, Edith. Mythology. Boston: Little and Brown, 1942.

Ives, E.W. Anne Boleyn. Oxford; New York: Basil Blackwell Ltd., 1987.

Lacey, Robert. Sir Walter Ralegh. Forge Village, MA: The Murray Printing Company, 1973.

Levin, Carole. The Heart and Stomach of a King: Elizabeth I and the Politics of Sex and Power. Philadelphia: University of Pennsylvania Press, 1994.

Lewalski, Barbara. "Anne of Denmark and the Subversions of Masquing." Criticism 35 (1993): 341-350.

Mackie, J.D. A History of Scotland. New York: Penguin Books, 1964. 
Malcolmson, Christina, and Mihoko Suzuki, ed. Debating Gender in Early Modern England, 1500-1700. New York: Palgrave Macmillan, 2002.

Mathew, David. James I. London: Eyre and Spottiswoode, 1967.

McManus, Clare, ed. Women and Culture at the Courts of the Stuart Queens. New York: Palgrave Macmillan, 2003.

"Women and English Renaissance Drama: Making and Unmaking The All-Male Stage." Literature Compass. 4, no. 3 (2007): 784-796.

Women on the Renaissance Stage: Anna of Denmark and Female Masquing in the Stuart Court (1590-1619). Manchester: Manchester University Press, 2002.

McNamara, Gregory Vaughn. “'A Perfect Diamond Set in Lead': Henry, Prince of Wales and the Performance of Emergent Majesty." Unpublished PhD dissertation, West Virginia University, 2000.

Meikle, Maureen M., and Leeds Barroll. "Review of Anna of Denmark, Queen of England: A Cultural Biography." The Sixteenth Century Journal 34, no. 3 (2003): 920-921.

Mulryne, J. R., and Margaret Shewring. Theatre and Government Under the Early Stuarts. Cambridge: Cambridge University Press, 1993.

Nicholls, Mark. "Treason's Reward: The Punishment of Conspirators in the Bye Plot of 1603." The Historical Journal 38, no. 4 (1995): 82.

Owen, D.D.R. Eleanor of Aquitaine: Queen and Legend. Oxford; Malden, MA: Blackwell Publishers Inc., 1999.

Parry, Graham. The Golden Age Restor'd: The Culture of the Stuart Court, 1603-42. New York: St. Martin's Press, 1981.

Patterson, W.B. James VI and I and the Reunion of Christendom. Cambridge: Cambridge University Press, 1997.

Peck, Linda Levy. Court Patronage and Corruption in Early Stuart England. Cambridge; London: Unwin Hyman Ltd., 1990.

Peck, Linda Levy. The Mental World of the Jacobean Court. Cambridge: Cambridge University Press, 1991.

Questier, Michael. "Catholic Loyalism in early Stuart England," The English Historical Review, 123, no. 504 (2008): 1132-1165.

Rait, Robert. Five Stuart Princesses. London: A. Constable, 1902.

Records of Early English Drama. "Elizabeth Tudor (1533-1602/3)." Accessed 28 Apr. 2012. <http://link.library.utoronto.ca/reed/eventhits.cfm?PeopleListID=533>.

RoyaList Online. "Family Tree for Anne of Denmark (Wife of King James I of England)." Date accessed: 17 Apr. 2012. < http://www.royalist.info/execute/tree?person=265>. 
Sharpe, Kevin. Politics and Ideas in Early Stuart England. New York; London: Pinter Publishers, 1989.

Smuts, R. Malcolm. Court Culture and the Origins of a Royalist Tradition in Early Stuart England. Philadelphia: University of Pennsylvania Press, 1987.

Spence, Richard T. Lady Anne Clifford. Phoenix Mill, Gloucestershire: Sutton Publishing Limited, 1997.

Stevenson, David. Scotland's Last Royal Wedding: The Marriage of James VI and Anne of Denmark. Edinburgh: John Donald, 1997.

Strong, Roy C. Henry, Prince of Wales and England's Lost Renaissance. New York: Thames and Hudson, 1986.

Warnicke, Retha M. Women of the English Renaissance and Reformation. Westport, CT; London: Greenwood Press, 1983.

Williams, Ethel Carleton. Anne of Denmark: Wife of James VI of Scotland, James I of England. London: Longmans Group Limited, 1970.

Willson, David Harris. King James VI and I. Oxford: Alden Press, 1962.

Woodcock, Matthew. "“Their Eyes More Attentive to the Show": Spectacle, Tragedy and the Structure of All Is True (Henry VIII)." Shakespeare 7, no. 1 (2011): 1-15. 